\title{
Pelagic communities of the South West Indian Ocean seamounts: R/V Dr
}

\section{Fridtjof Nansen Cruise 2009-410}

\author{
A.D. Rogers $^{1 *}$, O. Alvheim ${ }^{2}$, E. Bemanaja ${ }^{3}$, D. Benivary ${ }^{4}$, P. Boersch-Supan ${ }^{1,5 \ddagger}$, T.G.

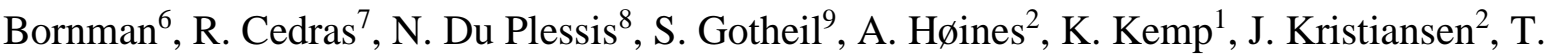

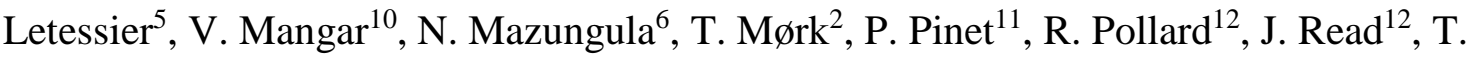 \\ Sonnekus ${ }^{13}$
}

1. Department of Zoology, University of Oxford, Tinbergen Building, South Parks Road, Oxford, OX1 3PS, United Kingdom.

2. Institute of Marine Research, P.O. Box 1870 Nordnes, 5817 Bergen, Norway.

3. IHSM Institut Halieutique et des Sciences Marines, Madagascar.

4. University of Tuléar, Madagascar

5. Pelagic Ecology Research Group, Scottish Oceans Institute, University of St Andrews, Fife, KY16 8LB, United Kingdom.

6. South African Environmental Observation Network, Elwandle Node, Private Bag 1015, Grahamstown 6140, South Africa.

7. University of the Western Cape, Dept. of Biodiversity \& Conservation Biology, Private Bag X17, Bellville 7535, South Africa.

8. University of Cape Town, Department of Oceanography, Rondebosch 7701, Cape Town, South Africa.

9. International Union for Conservation of Nature (IUCN), Rue Mauvernay 28, 1196 Gland, Switzerland.

10. Albion Fisheries Research Centre, Mauritius. 
11. ECOMAR Laboratory, Université de La Réunion, 15 avenue René Cassin, Saint Denis, 97715, France.

12. National Oceanography Centre, European Way, Southampton, SO14 3ZH, United Kingdom.

13. Nelson Mandela Metropolitan University, PO Box 77000, Port Elizabeth, 6031, South Africa.

*Corresponding author.

$\ddagger$ Present address: Department of Geography, University of Florida, Gainesville, FL and Department of Integrative Biology, University of South Florida, Tampa, FL

Keywords: Seamount, Pelagic Ecology, Oceanography, South West Indian Ridge 


\section{Abstract}

The seamounts of the southern Indian Ocean remain some of the most poorly studied globally and yet have been subject to deep-sea fishing fleets for decades and may face new exploitation through mining of seabed massive sulphides in the future. As an attempt to redress the knowledge deficit on deep-sea benthic and pelagic communities associated mainly with the seamounts of the South West Indian Ridge two cruises were undertaken to explore the pelagic and benthic ecology in 2009 and 2011 respectively. In this volume are presented studies on pelagic ecosystems around six seamounts, five on the South West Indian Ridge, including Atlantis Bank, Sapmer Seamount, Middle of What Seamount, Melville Bank and Coral Seamount and one un-named seamount on the Madagascar Ridge. In this paper existing knowledge on the seamounts of the southwestern Indian Ocean is presented to provide context for the studies presented in this volume. An account of the overall aims, approaches and methods used primarily on the 2009 cruise are presented including metadata associated with sampling and some of the limitations of the study. Sampling during this cruise included physical oceanographic measurements, multibeam bathymetry, biological acoustics and also net sampling of phytoplankton, macrozooplankton and micronekton / nekton. The studies that follow reveal new data on the physical oceanography of this dynamic region of the oceans, and also the important influence of water mass on the pelagic ecology associated with the seamounts of the South West Indian Ridge. New information on the pelagic fauna of the region fills an important biogeographic gap for the mid- to high-latitudes of ocean of the southern hemisphere. 


\section{Introduction}

The waters around southern Africa are rich in seamounts. Vema Seamount, for example, was the site of one of the first modern investigations of seamount biology (Simpson \& Heydorn, 1965). The waters of the South East Atlantic form one of the world's major eastern boundary current upwelling systems and host several significant ranges of seamounts including the Southern Mid-Atlantic Ridge, the Walvis Ridge, the Vavilov Ridge, the Aghulas Ridge and a number of more isolated seamounts (e.g. Vema Seamount) and rise features (e.g. Meteor Rise; see Fig. 1; SEAFO Scientific Committee, 2006; Clark et al., 2007; Bensch et al., 2008). The southern Indian Ocean also hosts significant submarine features including the Madagascar Ridge, the Mozambique Ridge and the South West Indian Ridge (SWIR), the last of which forms part of the global mid-ocean ridge system. Seamount ecosystems of both the South East Atlantic and South West Indian Oceans lie outside the main geographic foci of seamount research (North Atlantic, South West Pacific and North Pacific; Rogers et al., 2007), and basic information on species presence, biogeography and ecology are lacking. This is not the case for geological studies where the SWIR, and Atlantis Seamount in particular, have received considerable research effort directed at understanding the tectonics of ultraslow-spreading ridges (e.g. Dick et al., 2003). Recent exploration has also resulted in the identification of hydrothermal plumes along the SWIR (e.g. Bach et al., 2002) and the location of the first hydrothermal vent ecosystem (Tao et al., 2012; 2014).

Despite the lack of understanding of the ecology of seamounts around southern Africa, exploitation of the biological resources of these ecosystems has taken place for nearly 40 years. These fisheries were pioneered in the 1970s by the Soviet distant-water fishing fleet, which at the time was one of the largest in the world (Romanov, 2003). In the South East Atlantic, the Vavilov and Walvis Ridges were targeted for alfonsino (Beryx splendens and 
possibly Beryx decadactylus), cardinal fish (Epigonus denticulatus) and pelagic armourhead or boarfish (Pseudopentaceros richardsoni) (Clark et al., 2007). In the South West Indian Ocean the Soviet fleet targeted redbait (Emmelichthys nitidus) and rubyfish (Plagiogeneion rubiginosus) with catches peaking about 1980 and then decreasing to the mid-1980s (Clark et al., 2007). Fishing then switched to alfonsino in the 1990s as new seamounts were exploited. Some exploratory trawling was also carried out on the Madagascar Ridge and South West Indian Ocean Ridge by French vessels in the 1970s and 1980s, particularly targeting Walter's Shoals and Sapmer Bank (Collette \& Parin, 1991). In the 1990s and early 2000s new fisheries developed in both regions. In the South East Atlantic, both within the Namibian economic exclusive zone (EEZ) and in the high seas, along the Walvis Ridge, these fisheries targeted orange roughy (Hoplostethus atlanticus). In the southern Indian Ocean, a major fishery developed on the high seas, along the South West Indian Ocean Ridge, targeting orange roughy, black cardinal fish (Epigonus telescopus), pelagic armourhead, oreos (Oreosomatidae) and alfonsino (Clark et al., 2007). In both cases, fisheries were characterised by a very rapid expansion of fishing effort followed by a collapse in catches (Boyer et al., 2001; Branch, 2001; Clark et al., 2007). In the South West Indian Ocean, fishing shifted to the Madagascar Plateau, Mozambique Ridge and Mid-Indian Ocean Ridge, targeting alfonsino and rubyfish (Clark et al., 2007).

The rapid depletion of deep-sea fisheries are cause for significant international concern and are incompatible with current international law and agreements related to management of fisheries (Rogers \& Gianni, 2010). In the South East Atlantic, within the Namibian EEZ, rapid depletion of stocks of orange roughy reflected both the inherent vulnerability of the species to overexploitation, a lack of understanding of its biology and responses to fishing pressure (Boyer et al., 2001; Branch, 2001; Morato \& Clark, 2007). On the high seas, 
particularly in the South West Indian Ocean and high seas areas of the South East Atlantic, deep-sea fisheries developed without assessment of stock size, sustainable levels of exploitation or any other form of management (Lack et al., 2003). In the South West Indian Ocean, the result of this was a rapid decline in fisheries, particularly for orange roughy within the space of a few years (1999 - 2003; Lack et al., 2003).

Over recent years it has also become clear that the main method used in fishing deep-water species, bottom trawling, is associated with significant damage to benthic ecosystems, particularly communities formed by deep-water corals, sponges and other attached fauna that provide habitat for other marine species. Observations of significant adverse impacts of fishing on deep-water coral communities have been reported from the northeastern and northwestern Atlantic and the northeastern and southwestern Pacific (Stone, 2006; Stone \& Shotwell, 2007; Waller et al., 2007; Althaus et al., 2009; Williams et al., 2010). Such ecosystems have a poor capacity for recovery, as habitat-forming corals have slow growth rates, especially some Antipatharia and Octocorallia (Roark et al. 2006, 2009), and the coral habitat itself may have taken thousands of years to develop (Hall-Spencer et al., 2002). In some areas impacted by trawling, there have been observations of the occurrence on the seabed of small stylasterid corals and solitary Scleractinia as well as some octocoral species and urchins. These animals may not represent recovery of communities but rather are the elements of seamount communities that are resistant to trawling impacts, which live in refugia, or which live in refugia and subsequently spread to areas impacted by trawling (Clark \& Rowden, 2009; Williams et al., 2010). In many cases, little or no recovery of prefishing seabed ecosystems have been observed even years after fishing impacts (Waller et al., 2007; Althaus et al., 2009; Williams et al., 2010). Seamount ecosystems are now also recognised as biological hotspots, sometimes with a higher biomass and diversity of benthic 
species than adjacent continental slope regions (Rowden et al., 2010) or communities with a distinct structure (McClain et al., 2009, 2010), although this is certainly not always the case (Howell et al., 2010). They can also attract significant concentrations of ocean predators such as cephalopods, tunas, billfish, sharks, turtles, birds, pinnipeds, and cetaceans (Clarke, 2007, Holland \& Grubbs, 2007; Litvinov, 2007; Kaschner, 2007; Santos et al., 2007; Thompson, 2007). The impacts of deep-water fisheries on such animals through both direct impacts (bycatch of predators), to indirect impacts (disturbance and food-web effects), have not been resolved.

In the South East Atlantic, deep-sea fisheries on the high seas have now come under the regulation of a new regional fisheries management organisation (RFMO), the South-East Atlantic Fisheries Organisation (SEAFO). This RFMO has established total allowable catches (TACs) in its regulatory area for deep-sea species including orange roughy, alfonsino, pelagic armourhead, Patagonian toothfish and deep-sea red crab (SEAFO Scientific Committee, 2008). SEAFO have also undertaken measures to protect vulnerable marine ecosystems including: the closure of seamounts to fishing; the instruction of observers to collect data on by-catch of habitat-forming deep-sea species; support of scientific research on benthic ecosystems in the area; adoption of "move-on" rules when habitat-forming species are encountered by fishing vessels and the banning of gillnets in the SEAFO Regulatory Area.

In the Southern Indian Ocean an RFMO, the Southwest Indian Ocean Fisheries Commission (SWIOFC), was established in 2004, but focuses on the management of shallow-water fisheries, although some member states are investigating deep-water fisheries within their Exclusive Economic Zones (e.g. Mauritius or Mauritian dependencies on the Nazareth and St Brandon Banks; SWIOFC, 2009). In 2006, the South Indian Ocean Fisheries Agreement 
(SIOFA) was opened but ratification of this agreement was delayed until June, 2012. As this delay progressed it caused sufficient concern amongst several of the deep-water fishing companies in the area that in 2006 they formed an association to promote technical, research and conservation activities to furnish a future RFMO with data required for management of deep-water fisheries in the region (Shotton, 2006). This association is known as the Southern Indian Ocean Deepwater Fisher's Association (SIODFA). One of the first actions of this industry body was to declare a number of voluntary benthic protected areas (BPAs) in the South West Indian Ocean, including two seamounts, Coral Seamount and the Atlantis Bank, on the SWIR and part of Walter's Shoals, on the Madagascar Ridge (Shotton, 2006). These BPAs were established under a number of criteria, including scientific interest in the sites (e.g. Atlantis Bank) and the presence of a fauna indicative of the presence of vulnerable marine ecosystems such as cold-water coral communities (e.g. Coral Seamount; Shotton, 2006). Coral Seamount and Atlantis Bank were subsequently accepted as Ecologically and Biologically Significant Areas (EBSAs) under the Convention on Biological Diversity (see link to Southern Indian Ocean at: https://www.cbd.int/ebsa/ebsas). In addition, SIODFA declared two further BPAs, one in an area north of Walters Shoal (The Banana) and the other, part of Middle of What Seamount where significant areas of intact coral habitat were observed as part of the current project (SIODFA, 2013). SIOFA finally entered into force in June, 2012 with member states including: Australia, Cook Islands, the European Union, Mauritius and the Seychelles (http://www.fao.org/fishery/rfb/siofa/en).

To improve scientific understanding of the ecosystems and fisheries associated with the seamounts of the SWIR and to enhance the establishment of sustainable, ecosystem-based management of fisheries within the high seas of the Southern Indian Ocean, a new project was established. This was funded by the Global Environment Facility (GEF) of the World 
Bank, the Natural Environment Research Council (NERC) of the U.K. and the United Nations Development Programme (UNDP) through the Agulhas and Somali Current Large Marine Ecosystems project (ASCLME). The project, Applying an ecosystem-based approach to fisheries management: focus on seamounts in the Southern Indian Ocean (GEF Project ID 3657), was coordinated and supported by the International Union for the Conservation of Nature (IUCN), UNDP and the Fisheries and Agricultural Organisation of the UN (FAO). The Southern Indian Ocean seamounts project ran from 2009 to 2012 and involved participation by scientists from the United Kingdom, South Africa, Reunion, Madagascar and Mauritius, and by representatives of the fishing industry, mainly through SIODFA. The scientific effort in this project was focused on two cruises, the first, described here, which took place in November and December, 2009, was aimed at improving understanding of the pelagic ecosystem in the South West Indian Ocean and the interaction between the pelagic environment and both fished and unfished seamounts on the SWIR and the Madagascar Ridge. In November to December 2011, a second cruise focused on surveying the benthic ecosystems associated with the same seamounts took place. This second cruise also included physical oceanographic measurements and sampling of seawater for nutrient and microbiological analyses of the water column which is detailed in this volume (Djurhuus et al., 2017). In this paper the aims of this research project are outlined and the strategy and methods used in the first cruise on the R/V Dr Fridtjof Nansen are described.

\section{Strategy and Approach}

\subsection{The Environmental Setting of the Seamounts}

The SWIR separates the African and Antarctic Plates and has an ultra-slow spreading rate (full rate of $16 \mathrm{~mm}$ per year; Sauter et al., 2002). It extends approximately $7,700 \mathrm{~km}$ from the Rodriguez Triple Junction to close to Bouvet Island in the Southern Ocean (Sauter \& Cannat, 
2010). The ridge is characterised by a very deep ( $>5000 \mathrm{~m}$ in places) and rough mid-axial valley and is cut by a series of north - south running transform faults (Münch et al., 2001), such as the Atlantis II and Novara transform faults that lie either side of Atlantis Bank (Coogan et al., 2004). Near Marion Island / Prince Edward Island the ridge splits into two, one branch continuing as the SWIR and coming in to close proximity to the Mid-Atlantic Ridge at the Bouvet Triple Junction, the other forming the Madagascar Ridge. West of Bouvet Island in the Sub-Antarctic the SWIR terminates at the junction of the Bouvet Fracture Zone and the Spiess Ridge (Ligi et al., 1999; Fig. 1).

The Madagascar Ridge extends southwards from the microcontinent of Madagascar for about 700 miles (Fig. 1). The minimum depth is about $15 \mathrm{~m}$ on the summit of Walter's Shoals which is located roughly 400 nautical miles (nm; approx. $720 \mathrm{~km}$ ) south of Madagascar and 600 nautical miles east of South Africa, and have an estimated area of $400 \mathrm{~km}^{2}$ shallower than the $500 \mathrm{~m}$ depth isobath (Groeneveld et al., 2006). This large and shallow seamount is covered, at its shallowest depths, with rhodoliths, formed predominantly by the calcareous algae Mesophyllum syrphetodes and Tenarea tessellata (Collette \& Parin, 1991), and coral (Romanov, 2003). The slopes of the Shoals are reported to be steep. Other seamounts along the Madagascar Ridge are reported to have summit depths between $84 \mathrm{~m}$ to $1100 \mathrm{~m}$ (Romanov, 2003).

The SWIR and Madagascar Ridge lie in a region of the southern Indian Ocean dominated by a Sub-Tropical Anticyclonic Gyre (Demopolous et al., 2003; Sultan et al., 2007; Fig. 2). Topographic constraints exerted by the Madagascar Ridge and SWIR forces the separation of three small anticyclonic cells within the Sub-Tropical Anticyclonic Gyre, two to the east of the Madagascar Ridge and one between the Madagascar Ridge and South Africa (Sultan et 
$a l ., 2007)$. The western boundary of the Sub-Tropical Anticyclonic Gyre is associated with a strong southward transport of water ( 55Sv) associated with the Agulhas Current. This current retroflects eastwards between $16^{\circ}$ and $20^{\circ} \mathrm{E}$ to become the Agulhas Return Current (Lutjeharms \& Van Ballegooyen, 1988; Fig. 2). Through the region of the present investigation, the southern boundary of the Agulhas Return Current is marked by the Agulhas Front which lies to the north of the Sub-Tropical Front, to the south of which lies the Antarctic Circumpolar Current (ACC; Read et al., 2000; Fig. 2). The Agulhas Front has the steepest density gradient of any in the Southern Ocean, is narrow, with an average width of only $96 \mathrm{~km}$, has a temperature of $21^{\circ} \mathrm{C}-15.7^{\circ} \mathrm{C}$, is optically clear, nutrient impoverished and is limited to about $40^{\circ} \mathrm{S}$ ( Read et al., 2000). The Agulhas Front can compress closely to the Sub-Tropical Front so the two can be difficult to distinguish (Read \& Pollard, 1993). The proximity of the Agulhas Return Current and the Sub-Tropical Front can lead to extreme temperature gradients (up to $1^{\circ} \mathrm{C}$ per $\mathrm{km}$; Read et al., 2000).

The Sub-Tropical Front forms the poleward boundary of warm salty water from the South Atlantic sub-tropical gyre (Read et al., 2000). It has mean latitude of 4140'S (Lutjeharms \& Valentine, 1984), although its north-south position varies considerably. It is associated with a marked gradient in temperature, of up to $7^{\circ} \mathrm{C}$ and salinity of up to $0.5 \%$ (Lutjeharms, 1985 ; Whitworth \& Nowlin, 1987; Lutjeharms et al., 1993). It is a surface feature associated with the upper $300 \mathrm{~m}$ of the water column and its position and shape are influenced by bottom topography (Weeks \& Shillington, 1996).

Below the surface water layers, in the regions to the north of the front, Sub-Antarctic Mode Water is located at the thermocline. This water is ventilated in the Southern Ocean, north of the Sub-Antarctic Front, and is associated with a maximum in oxygen. It moves with the 
subtropical gyre (McDonagh et al., 2008). This water mass is found down to about $500 \mathrm{~m}$ depth, in the vicinity of the SWIR. Below it occurs Antarctic Intermediate Water, which is also ventilated in the Southern Ocean, but is identified by a salinity minimum (McDonagh $e t$ al., 2008). This water reaches to about $1500 \mathrm{~m}$ depth around the SWIR. Underlying this water mass is Upper Deep Water which comprises mainly Indian deep water. It flows south and forms part of the Indian Ocean overturning circulation (Fig. 2). It exhibits an oxygen minimum, and high levels of inorganic nutrients (McDonagh et al., 2008), and penetrates to about 2000m depth.

The deep-water circulation of the region is quite different to the shallow circulation. Between 2000 and 3500m depth, modified North Atlantic Deep Water (NADW) flows into the Indian Ocean (McDonagh et al., 2008) along the African continental slope, up through the Mozambique Channel and also around the southern SWIR and Del Cano Rise (Van Aken et $a l ., 2004$; Fig. 2). In the north western part of the region the NADW flows up along the eastern slope of the Madagascar Ridge and then on over the Madagascar Ridge at about $35^{\circ} \mathrm{S}$. An additional flow comes through the SWIR via the Discovery Fracture Zone in the south (Van Aken et al., 2004; Fig. 2). This water eventually forms Circumpolar Deep Water (McDonagh et al., 2008).

Below this, the flow of Antarctic Bottom Water into the Indian Ocean is controlled by the SWIR. The main flow, from the Enderby Basin in to the Aghulas Basin, is between $20^{\circ}$ and $30^{\circ} \mathrm{E}$, probably via deep channels ( $>4000 \mathrm{~m}$ depth) in the ridge (Boswell \& Smythe-Wright, 2002). This water continues to flow northwards between the gap between the Agulhas Plateau and SWIR and then onto the Mozambique Channel. Another branch crosses the ridge at 35- 
$36^{\circ} \mathrm{S}$ through the Prince Edward Fracture Zone whilst a third branch passes along the southern flank of the Del Cano Rise (Boswell \& Smythe-Wright, 2002).

Overall, the SWIR is set within an area where the Agulhas Return Current, the Sub-Tropical Front and the Sub-Antarctic Front, further to the south (Fig. 2), create one of the most energetic and important hydrographic regions of the world (Read et al., 2000). The seamounts of the SWIR lie within an area of complex biogeochemistry, phytoplankton composition and productivity associated with the transition from sub-tropical conditions to sub-Antarctic (Bathmann et al., 2000) whilst those on the Madagascar Ridge lie within the Sub-Tropical Anticyclonic Gyre.

The Sub-Tropical/Sub-Antarctic Front has been associated with elevated concentrations of phytoplankton and zooplankton compared to the seas to the north and south (Froneman et al., 1998) and has been identified as a region important in carbon sequestration in the oceans (Llido et al., 2005). At the front, peak chlorophyll concentrations of $>1 \mu \mathrm{g} \mathrm{l}^{-1}$ have been recorded with microphytoplankton making up a significant proportion $(\sim 10 \%)$ to total chlorophyll. Outside this region, with the exception of the Sub-Antarctic Front, chlorophyll concentrations have been measured at $<0.9 \mu \mathrm{g}^{-1}$ and the nano- and picophytoplankton assemblages may be dominant (Froneman et al., 1998). It is thought that the accumulation of phytoplankton cells at the front, stability of the water column and availability of nutrients, especially iron may all contribute to elevated chlorophyll measurements (Lutjeharms et al., 1985; Weeks \& Shillington, 1996; Froneman et al., 1998). The enhanced primary productivity of the Sub-Tropical Convergence Zone occurs in intermittent pulses in spring and summer (Llido et al., 2005). Species diversity of microphytoplankton may also peak at the Sub-Tropical Convergence as a result of mixing of species from different water masses and unique biochemical conditions which lead to a unique planktonic community that is 
poorly characterised, especially in regions away from continents (Froneman et al., 1998; Barange et al., 1998; Longhurst, 1998; Richoux \& Froneman, 2009). Recent stable-isotope studies have also demonstrated that planktonic food webs undergo significant changes across the sub-tropical convergence in response to differing availability of phytoplankton and smaller zooplankton size classes (Richoux \& Froneman, 2009). Thus, the seamounts along the SWIR are likely to be in contrasting productivity regimes depending on their proximity to the Sub-Tropical Convergence and the Sub-Antarctic Front. Advection of surface production to the benthos of seamounts will depend on the depth of the seamount summit and the current regimes around seamounts (Rowden et al., 2005; White et al., 2007). The Sub-Tropical Convergence is also thought to represent a major biogeographic boundary in the Southern Indian Ocean dividing two distinct faunal provinces of the pelagic biota (Vierros et al., 2009).

Data on the diversity of biological communities of the southern Indian Ocean up to the 2009 cruise were sparse. More studies have been undertaken on Walter's Shoal than on the SWIR, probably because the former is closer to land than the latter and because of interests in commercial fisheries in the region. The shoal was sampled during the Indian Ocean expedition in 1964 by the R/V Anton Bruun and subsequently by the R/V Vityaz. These collections included a new endemic sub-species of crinoid, Comanthus wahlbergi tenuibrachia (Clark, 1972), prevalent in the shallow-waters of the shoal (Collette \& Parin, 1991), and several crustaceans including an endemic species of alpheid shrimp (Alpheus waltervadi; Kensley, 1981) and an endemic isopod, Jaeropsis waltervadi (Kensley, 1975). Recently, an endemic species of rock lobster, Palinurus barbarae, has been described from the shoals following the landing of the species from commercial fishing vessels (Groeneveld et al., 2006). Collette and Parin (1991) described the fish fauna from $400 \mathrm{~m}$ depth to the 
surface on the shoal (summit depth approx. 15m) and identified 20 species of which several were potentially endemic undescribed species, several were widespread temperate or subtropical species and several were Indo-Pacific reef associated species. Biogeographic affinities of elements of the shallow fish fauna with Gough Island, Tristan da Cunha and St Pauls and Amsterdam Islands (West Wind Drift Islands) were identified, particularly in the occurrence of species such as Helicolenus mouchezi, Trachurus longimannus and Serranus novemcinctus (Collette \& Parin, 1991). Others are found in Australia and New Zealand (Acantholatris monodactylus, Lepidoperca coatsii, Nelabrichthys ornatus). Helicolenus mouchezi and possibly several other species from Walter's Shoal also occur on the SWIR. The implication is that the Sub-Tropical Anticyclonic Gyre and Antarctic Circumpolar Current and/or other westerly flowing currents have assisted in transoceanic dispersal of these species, with islands and seamounts acting as stepping stones. Russian exploration of the Madagascar Ridge in the search of fisheries resources identified: dories (Oreosomatidae), sharks, Alepocephalus sp., Beryx sp., Macrouridae, Moridae, Plagiogeneion rubiginosum, Polyprion americanus, Polyprion oxygeneios, Pseudopentaceros richardsoni, scabbard fish, Scorpaenidae, Trachurus longimannus, tuna and members of the family Uranoscopidae.

Vereshchaka (1995) summarised several investigations on the macrozooplankton occurring on slopes and seamounts in the Indian Ocean. The paper lists a large number of taxa as occurring on Walter's Shoal and identified that species fall into two distinct group, those that were associated mainly with the water column and decrease in numbers towards the seabed, and those that are associated with the seabed. The latter group fall into several categories including: animals that are found near the seabed at night but disappear by day, presumably because they migrate to benthic habitats during daylight hours; animals found well above the 
seabed by night and descend to the seabed by day; larval animals which are found mainly over areas of seabed inhabited by adults (Vereshchaka, 1995).

Investigations of high seas areas of the Indian Ocean for fisheries resources were undertaken by Soviet research vessels and exploratory fishing vessels from the 1960s to 1998. Whilst detailed information is not available, the following species were identified as being present on the SWIR: Alepocephalus spp., Antimora rostrata, Beryx splendens, Beryx decadactylus, Centrolophus niger, Chauliodontidae, Dissostichus eleginoides, Electrona carlsbergi, Epigonus spp., Gonostomatidae, Helicolenus mouchezi, Hyperoglyphe antarctica, Lepidopus caudatus, Macrourus carinatus, Myctophidae, Nemadactylus macropterus, Neocyttus rhomboidalis, Notothenia squamifrons, Plageogeneion rubiginosum, Polyprion americanus, Polyprion oxygeneios, Promethichthys prometheus, Pseudopentaceros richardsoni, rays, Ruvettus pretiosus, Schedophilus huttoni, Schedophilus maculatus, Schedophilus velaini, sharks, Trachurus longimannus (Romanov, 2003). A more extensive species list is given in Romanov (2003) but this list is for all the seamounts sampled in the Indian Ocean from 19691998. It was noted that seamounts on the SWIR showed a marked variation in the fish present. For example, pelagic armourhead, Pseudopentaceros richardsoni, was almost exclusively caught on Seamount 690 (Romanov, 2003), which corresponds in position to Atlantis Seamount. Some of the species listed, such as Dissostichus eliginoides and Electrona carlsbergi are exclusively Antarctic / Sub-Antarctic.

Geological investigations have reported lobsters, crabs, sharks, sea fans, siphonophores, sponges and other benthic organisms on Atlantis Bank on the South West Indian Ocean Ridge (Dick, 1998). A single paper on ROV investigations reported the presence of crow shark (Etmopterus pusillus), orange roughy (Hoplostethus atlanticus) and warty oreo 
(Allocyttus verrucosus) all of which exhibited specific depths distributions (Lindsey et al., 2000). Other species observed included several putative species of bellows fish (Centriscops spp.), cutthroat eels (Synaphobranchus spp), rattail fish (Coryphaenoides spp., and possibly Hymenocephalus or Ventrifossa), attenuated spider fish (Bathypterois atricolor), a chimaera, tadpole whiptail (Squalogadus modificatus), a halosaur (Alvodrandia spp.), a morid cod (Lepidion capensis), several perciform fish (Haemulidae) and false cat sharks (Pseudotriakis microdon; Lindsey et al., 2000). Several benthopelagic or benthic shrimps were observed including Hepomadus sp., Nematocarcinus spp., and c.f. Acanthephyra, as well as sergestids and swarms of euphausiids above the seamount (Lindsey et al., 2000). Cirrate octopuses and squid were also observed as well as a pelagic holothurian. One of the photographs in the paper shows bellows fish in amongst colonies of Antipatharia and Octocorallia (Lindsey et al., 2000).

As with invertebrates and fish, knowledge of the distribution of aquatic predators, including cetaceans and birds, are sparse in the region. There have been sightings of concentrations of humpback whales in the vicinity of Walter's Shoal (e.g. Collette \& Parin, 1991; Shotton, 2006), suggesting that it may be an important migratory area between high latitude feeding grounds and low latitude breeding grounds off Madagascar (Findley, 2009). There are also reports of pilot whales, humpback whales and sperm whales in the areas where deep-water fishing takes place in the Southern Indian Ocean although it is not clear where these were (Shotton, 2006).

Shotton (2006) reported that sightings of birds are rare in the areas of fishing, and these were rarely seen north of $35^{\circ} \mathrm{S}$. White chinned petrels (Procellaria aequinoctialis) had been reported as occurring in areas of deep-water fishing and cape pigeons (Daption capense) and 
sooty shearwaters (Puffinus griseus) were reported as being observed from fishing vessels (Shotton, 2006). Bird observations taken from a cruise between La Réunion, Crozet, Kerguelen, St. Paul, Amsterdam Islands, and Perth, Western Australia identified 51 species of birds from over 15,000 sightings (Hyrenbach et al., 2007). During this cruise the density of birds increased significantly across the Sub-Tropical Convergence from 2.4 birds km $\mathrm{km}^{-2}$ in subtropical waters to 23.8 birds $\mathrm{km}^{-2}$ in sub-Antarctic waters. The taxonomic composition of birds also differed markedly in the 3 areas with prions (Pachyptila spp.) accounting for 57\% of all sub-Antarctic birds, wedge-tailed shearwaters (Puffinus pacificus) accounting for $46 \%$ of all subtropical birds, and Indian Ocean yellow-nosed albatross (Thallasarche carteri) accounting for $32 \%$ of all birds in the sub-tropical convergence zone (Hyrenbach et al., 2007). Given that this cruise transited part of the SWIR it would seem likely that significant numbers of seabirds are present in the vicinity of the seamounts, particularly in the more southerly areas.

\subsection{The aims of the project}

The Southern Indian Ocean seamounts project was focused on a number of scientific questions of relevance to management of deep-sea fisheries in the region. In the context of the R/V Dr Fridtjof Nansen Cruise the key questions included:

- What is driving the seamount fisheries (energy supply to the seamount ecosystems)?

- What are the pelagic communities of southern Indian Ocean seamounts like, how diverse are they (global importance, biogeography)?

- What influence do the seamounts of the SWIR exert on the pelagic ecosystem?

- What are the impacts of the past and current deep-sea fishing activities on seamount ecosystems? 
- Could the BPAs actually benefit fishing?

- Which seamounts should be fully protected because of their high ecological value, and which others can remain open to fishing subject to regulations to prevent significant adverse impacts to marine biodiversity?

Such a range of questions demanded a multidisciplinary scientific approach addressing aspects of geology, physical oceanography, pelagic ecology, and observations of aquatic predators.

\subsection{Geographic scope of studies}

Five seamounts were selected for investigation along the SWIR (Table 1, Fig. $1 \& 2$ ). These seamounts included both features that were designated as BPAs by SIODFA and those that remained unprotected but still subject to fishing. The seamounts were located north of the Sub-Tropical Convergence and to the south, in sub-Antarctic waters, and they represented a range of morphologies and summit depths from $\sim 90 \mathrm{~m}$ to $1000 \mathrm{~m}$ (see Table 1 \& Fig. 1 \& 2). In addition, a seamount to the north of Walter's Shoals was identified from Gebco as a comparative site on the Madagascar Ridge, to be investigated, should time allow on the cruise. This site was surveyed and found to have a summit depth much deeper than indicated by Gebco bathymetry (Table 1). In addition, four non-seamount locations were selected for study as a comparison to seamount stations, three to the north of the Sub-Tropical Convergence Zone and one to the South of the Sub-Tropical Convergence (Table 1). Two CTD sections with phytoplankton sampling were also taken across the Sub-Tropical Convergence to investigate the structure of the water column and changes in fluorescence, chlorophyll, and the phytoplankton community across the complex frontal systems lying above the SWIR (Fig. 2; see below). 


\subsection{Sampling strategy}

In order to achieve a quasi-synoptic picture of the pelagic ecosystems along the SWIR a combination of sampling strategies were employed on the R/V Dr Fridtjof Nansen. This involved (a) continuous observations along the ships track (b) point observations at predetermined stations at the seamounts, non-seamount sites and CTD sections. Because of the limitations of operating with a single cruise across such a large section of ridge sampling was restricted to the upper $1500 \mathrm{~m}$ of the water column. This was because of time constraints and also because the influence of the deep-scattering layer of diurnally migrating organisms was likely to have most influence in this depth range. Regardless of logistical constraints, the effective operation of much of the equipment used during the surveys (e.g. split-beam acoustics, net monitors etc.) was restricted to depths of less than $1200 \mathrm{~m}$ anyway.

\subsubsection{Continuous observations}

Continuous observations were undertaken as the vessel was underway to achieve several aims:

- To document the large-scale changes in the physical environment

- To map the vertical and horizontal distribution in biological backscatter down to $1000 \mathrm{~m}$ depth.

- To map the density and diversity of aquatic predators (birds \& cetaceans) along the cruise track and on stations associated with, or not associated with seamounts.

The sampling equipment used included:

Split beam echosounders 
Acoustic data were collected using a calibrated Simrad EK60 split-beam scientific echosounder (Kongsberg Maritime AS, Horten, Norway) operating at 18, 38, 120 and 200 kHz. The transducer array was mounted on the drop keel of R/V Dr Fridtjof Nansen at a deployed depth of $8.0 \mathrm{~m}$. The EK60 was operated in synchronisation with a vessel mounted ADCP and a bottom-mapping multibeam echosounder, with the EK60 $38 \mathrm{kHz}$ transducer setting the master ping rate. Pings were transmitted with a pulse duration of $1024 \mathrm{~ms}$. Acoustic signals were digitised and processed with Simrad ER60 software (Kongsberg Maritime AS, Horten, Norway) and logged in a raw format for post processing. Acoustic data quality was monitored in real-time using the ER60 software and near real-time using Echoview software (Myriax Pty Ltd. Hobart, Tasmania, Australia).

Transducer parameters were estimated by calibration following the procedures of Foote et al. (1987). The most recent calibration was conducted by the Nansen's technical staff on 14th

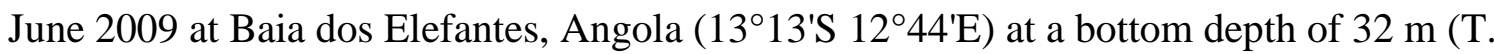
Mørk, personal communication).

A copper calibration sphere (diameter $64 \mathrm{~mm}$ ) was used for the $18 \mathrm{kHz}$ sounder, a copper sphere (diameter $60 \mathrm{~mm}$ ) was used for the $38 \mathrm{kHz}$ sounder and a tungsten carbide sphere (diameter $38.1 \mathrm{~mm}$ ) was used for the 120 and $200 \mathrm{kHz}$ sounders. Theoretical target strengths for those spheres were adjusted to the speed of sound as calculated from local water temperature and salinity $(c=1518 \mathrm{~m} / \mathrm{s})$. Parameter estimates are given in Appendix 1.

\section{Acoustic Doppler Current Profiler (ADCP)}

A hull-mounted ADCP was used to record current sheer throughout the cruise. The instrument was an RDI Ocean Surveyor $150 \mathrm{kHz}$ model, system serial number 1533 and transducer 3067 running vmDAS version 1.44 with $30^{\circ}$ beam angle. Transmissions were 
synchronised with the other acoustic equipment on board (EM710, EK60), such that the ADCP was triggered by the $38 \mathrm{kHz}$ transducer of the EK60 to ping, before it transmitted. This led to a lower data rate than the instrument is capable of but it provided good data over the top 300-400 m of the water column for most of the cruise.

The instrument was configured with one hundred $8 \mathrm{~m}$ bins, $8 \mathrm{~m}$ blank beyond transmit and zero transducer depth. Bin depths were corrected during processing using the RDI formula Central depth of first bin $=$ blank distance $(\mathrm{WF})+0.5 *($ bin size $+\mathrm{xmt}$ length + lag $)$ Where the blank distance $=10 \mathrm{~m}$, bin size $=8 \mathrm{~m}, \mathrm{xmt}$ length $=8 \mathrm{~m}$ and lag $=0.74 \mathrm{~m}$. Together with the vessel's draft of $5.5 \mathrm{~m}$, an estimated first bin depth of $24 \mathrm{~m}$ was applied. Individual pings were internally corrected for ship's heading using the 1 second NMEA input from the Seatex Seapath 200. Data were averaged internally over 3 minutes (STA) and 20 minutes (LTA). During the cruise, the 3-minute averages were read into pstar, corrected for ship's velocity and plotted for the acoustic grids, CTD yoyo's and transects. No calibration for misalignment angle was attempted during the cruise. The first acoustic survey (event 2) provided coherent data (i.e. no divergence between the lines of the grid) indicating that any misalignment angle must be small.

The Seatex Seapath 200 (S/N 2261) integrated navigation sensor of the R/V Dr Fridtjof Nansen provided real-time heading, attitude, position and velocity. These were obtained by integrating the signals from an inertial measurement unit (MRU 5) and two GPS antennae. The Seatex MRU 5 incorporated 3-axis sensors to measure linear acceleration and angular rate and the output was processed in the Seapath processing unit using a Kalman filter to produce roll, pitch, heave and velocity measurements. Roll, pitch and heading were passed to the vessel's ADCP in NMEA format. 


\section{Thermosalinograph}

Surface measurements of temperature, salinity and fluorescence were made using a Seabird SBE 21 SeaCat thermosalinograph. Data were presented as 1 minute averages in the daily cnv files. Meteorological measurements were provided, although no air pressure was recorded in the data files.

Weather recording system

Meteorological data logged from the Norwegian Meteorological Institute (DNMI) meteorological station included air temperature, humidity, air pressure, wind direction and speed, and sea surface temperature (SST). All data were averaged by unit distance sailed (1 $\mathrm{nm}$ ). The incoming irradiance or PAR (photosynthetic irradiance) was recently removed from the meteorological system and so these data were not available.

\section{Cruise log system}

Cruise data was logged using the NANSIS Survey Information System for logging, editing and analysis of biological and environmental data from marine research surveys (available at - http://www.imr.no/forskning/bistandsarbeid/nansis/nansis/en)..

The key features of this software are:

- Main database: Postgres SQL for safe storage of data and linking with other databases;

- Track log module: for logging and visualization of continuously recorded data, weather stations, GPS and echosounder data;

- Bridge log module: vessel activity diary;

- Nansis main window for work with survey data including: 
- Initialization of new surveys

- Data punching modules for data collected during research surveys

- Reporting system of collected data

- Scripting module and Nansis Post Processing

- Nansis Map tool: data visualization and biomass estimation;

- Nansis briefcase: transfer of data between two databases;

- Spread sheet like export facilities to link up with other analytical and map software;

- Nansis help menu for installation and use of all modules in the system.

\section{Multibeam echosounder}

Surveys of the entire cruise track and of seamount bathymetry were undertaken using a SIMRAD EM710 70 - 100 kHz multibeam echosounder (Kongsberg Maritime AS, Horten, Norway). This is a high-resolution seabed mapping system which, on the R/V Dr Fridtjof Nansen is logged onto the Olex navigation system (Olex AS, Pirsenteret N-7462, Trondheim, Norway). The minimum acquisition depth is from less than $3 \mathrm{~m}$ below its transducers, and the maximum acquisition depth is approximately $2000 \mathrm{~m}$, somewhat dependent upon array size. Across track coverage (swath width) is up to 5.5 times water depth, to a maximum of more than $2000 \mathrm{~m}$ and the depth resolution is $1 \mathrm{~cm}$ (Kongsberg Maritime). The transmit fan is divided into three sectors to maximize range capability, but also to suppress interference from multiples of strong bottom echoes. The sectors are transmitted sequentially within each ping, and use distinct frequencies or waveforms. All acoustic instruments used during the cruise were triggered by the $38 \mathrm{kHz}$ signal from the SIMRAD EK60. Timing of each instrument can be finely adjusted on the vessel to avoid interference between instruments if the vessel is, for example, operating in shallow water. The model on the R/V Dr Fridtjof Nansen is a $1 \times 2^{\circ}$ model which generates 128 beams/200 soundings per ping. Following collection of raw data 
for each seamount, data was filtered to remove obvious bad pings (echos that are much higher or lower than background).

\section{Predator observations}

During the entire mission, two observers (EB, PP) surveyed marine birds and mammals. Observations were made from the unenclosed bridge of the vessel Dr Fridtjof Nansen during daylight hours while the vessel cruised at speeds around 10 knots. Following the transect methods (Tasker et al., 1984), a 300m strip-width transect band was used, with the two observers surveying each sides of the vessel (i.e., $600 \mathrm{~m}$ band). Censuses were continuous, all individuals or groups being identified at the lowest possible taxonomic level. The observer on watch estimated the number of seabirds in the flock, all taxa combined. If more than one taxon was present, percent composition of each species in the flock was also estimated. The behaviour of each bird (sitting, flying, feeding, ship following) and the presence of surfacedwelling fishes or mammals were recorded. Photography was also taken during each transect in order to help determination of species identifications. Also, when the ship was stopped, many observations were made opportunistically in order to complete the seabird sightings but were not taken into account for the density analysis (presence only).

During the cruise, two types of census were undertaken:

1) Transects between seamount stations (see Table 2 for surveyed transects)

2) On the seamounts, four transects were selected along the $10 \mathrm{~nm}$ grids for acoustic surveys, representing $24 \mathrm{~km}^{2}$ surveying per station (see Table 2 for seamounts surveyed).

The results of these surveys are not presented in this volume. 


\subsubsection{Point sampling at seamount and non-seamount stations}

Hypotheses relating to what drives the biological communities of seamounts fall into two main categories, (a) enhanced primary productivity or (b) trophic focusing (Rogers, 1994; Genin, 2004; Genin \& Dower, 2007). Enhanced primary production is theoretically possible if current - topography interactions lead to upwelling of nutrient rich deep water around a seamount, or enhance the stability or mixing of the water column above a seamount (White et $a l ., 2007)$. Typically, this form of enhancement of primary production was thought to be possible where the presence of a Taylor column or cone was generated by the flow of water past the summit of a shallow seamount (Rogers, 1994; Clark et al., 2010). However, observations of long lasting elevated levels of plankton over seamounts are rare (Genin \& Dower, 2007), with the best example probably being the North West Georgia Rise, in the South Atlantic. Here, a Taylor Column, a warm-core anticyclonic circulation, is frequently generated enhancing primary productivity above the bank (Meredith et al., 2003). However, the presence of this feature is influenced by the strength of the Southern Antarctic Circumpolar Current Front and it cannot be regarded as permanent (Meredith et al., 2003). Tidal forcing may be an alternative mechanism that can generate rectified flows above seamounts. Tidally forced circulation can generate anticyclonic flow above seamounts and a cold, dense dome over the seamount similar to a Taylor column (White et al., 2007). Tidallydriven phenomena such as anticyclonic vorticity, the formation of trapped or internal waves can be important in current acceleration and turbulent mixing, influencing the distribution of suspension feeding benthic communities (Clark et al., 2010).

Trophic focusing may occur through a variety of mechanisms, including the trapping of the diurnally migrating elements of the deep-scattering layer (topographic blockage), asymmetric flow acceleration on the flanks or summits of seamounts leading to enhanced horizontal flux 
of organic material (phytoplankton, zooplankton) across a seamount or advection of such material from the far field (White et al., 2007). There are also potential links in benthic and pelagic food webs that may enhance productivity in fish populations around seamounts (Pitcher \& Bulman, 2007). Investigations of the diet of benthopelagic fish on Seine Seamount (summit depth $\sim 170 \mathrm{~m}$ ), in the North Atlantic Ocean, indicated that they relied on pelagic food sources but that these were mainly non-migrating or weakly migrating zooplankton (mainly copepods; Hirch \& Christiansen, 2010). This suggests that diurnally migrating zooplankton and micronekton were not an important component of the diet of seamountassociated benthopelagic fish as would be expected with the topographic blockage hypothesis (Hirch \& Christiansen, 2010).

Ascertaining which physical and biological processes may be in operation at the seamounts of the SWIR required a combination of observations relating to geomorphology of the seamounts, oceanography, acoustics, and biology, the latter ranging from analyses of phytoplankton communities and particulate organic carbon to net sampling of zooplankton, micronekton and fish communities. Each seamount was mapped, a stratified acoustic survey of the deep scattering layers undertaken and at least one CTD transect taken across the seamount to analyse general structure of the water column and currents. A 24 hour CTD YoYo was also undertaken on the flanks or summit of each seamount to analyse tidal effects on the hydrographic structure including the identification of upwelling events or generation of internal wave features. Biological sampling was aimed at assessing the possibilities of enhanced primary production around seamounts and for ground-truthing of acoustic surveys as well as studies associated with biodiversity of pelagic communities. This sampling included the use of a large pelagic trawl (Åkra trawl) capable of sampling large size-classes of fish (up to $>1 \mathrm{~m}$ in length) for studies associated with trophic focusing on the target 
seamounts. Non-seamount stations did not require detailed CTD observations through transects or CTD Yo Yos whilst CTD sections involved only measurements associated with oceanography and phytoplankton studies (Table 3). The location of each seamount and nonseamount station is listed in Table 1, the location of CTD section stations are listed in Table 2.

\section{Biological net sampling}

Phytoplankton net

An $80 \mu \mathrm{m}$ ring net (Fig. 3) was deployed vertically to below the Deep Chlorophyll Maximum (DCM) and winched up to the surface at $0.5 \mathrm{~m} \mathrm{~s}^{-1}$. The contents of the cod-end were washed into a $250 \mathrm{ml}$ honey jar containing $2 \%$ Lugols solution and stored for later analyses. Stations are recorded on Table 2.

\section{Multinet mesozooplankton sampler}

Mesozooplankton samples were collected with Hydrobios MultiNet MiDi zooplankton sampler that takes up to five discrete samples at predefined depths while measuring the water flow through the net (Fig. 4). The Multinet has a $50 \times 50 \mathrm{~cm}$ mouth opening and $180 \mu \mathrm{m}$ mesh size and was fished obliquely to take samples from 5 depth strata (Falkenhaug 2007; Hosia et al. 2008; Wenneck et al. 2008). While the ship was steaming at $0.3-0.5 \mathrm{~m} . \mathrm{s}^{-1}$ the Multinet was lowered to a maximum of $200 \mathrm{~m}$. Nets were then triggered at the selected depth intervals. Net changing was controlled by down-wire link from a Net Command Unit. The volume of water filtered was measured by Hydrobios Electronic Flowmeters situated internally and externally on the net frame and was between 8 and $200 \mathrm{~m}^{3}$ per net. Nominal depth intervals alternated between two sets of standards deployments: Stratified/Biogeographic and Fmax. 
Upon recovery of the multinet samples were rinsed into the cod end and thoroughly washed into a sieve with a $180 \mu \mathrm{m}$ mesh. The contents of the sieve were then washed into a sample jar using a water bottle filled with ambient seawater retrieved from the cod-ends and split into two fractions using a Folsom splitter (Sell \& Evans, 1982). One fraction was preserved on 95\% ethanol for genetic analysis and the other was preserved on $4 \%$ borax- buffered formaldehyde. We visually inspected multinet samples for diversity and bio-volume estimates.

For DCM studies, samples were washed through a $180 \mu \mathrm{m}$ sieve and fixed in $4 \%$ boraxbuffered formaldehyde. Sample jars were placed in a black plastic boxes for 24 hours. After 24 hours, the approximate volume of zooplankton in each sample was recorded using a ruler (in $\mathrm{mm}$ ) and the data were entered into a log. The main types of zooplankton observed in each sample were also identified and recorded. Thereafter, the samples were placed back into the black boxes for storage and for further laboratory analysis subsequent to the cruise.

\section{Bongo nets}

A bongo net with $375 \mu \mathrm{m}$ and 500 $\mu \mathrm{m}$ mesh nets was deployed at all stations (Fig. 5). Three replicate samples from day time and night time hauls were treated in different ways. For one net out of three, the $375 \mu \mathrm{m}$ net was carefully washed through $1 \mathrm{~mm}$ and $64 \mu \mathrm{m}$ sieves. Thereafter each zooplankton size-fractioned sample was placed into a blue opaque vile and dried in an oven at $50^{\circ} \mathrm{C}$. The sample from the $500 \mu \mathrm{m}$ net was washed into a $180 \mathrm{ml}$ honey jar and immediately preserved in $4 \%$ buffered formaldehyde for analyses of fish larvae. 
For the second net the 500 and $350 \mu \mathrm{m}$ nets were washed through $1 \mathrm{~mm}$ and $64 \mu \mathrm{m}$ sieves and were immediately preserved in $10 \%$ seawater formaldehyde. In the final net the $500 \mu \mathrm{m}$ net codend was removed and the mesozooplankton were preserved in formalin for subsequent taxonomical analysis. Samples from the $375 \mu \mathrm{m}$ net cod-end were removed and preserved on ethanol for subsequent genetic analysis of species diversity.

Double-warp fish trawl (Åkra trawl)

Two pelagic Ákra trawls were used for fishing. The larger net, a Flytetrål 152 MSK x $3200 \mathrm{~mm}$, with a 20m net mouth opening, was used for most trawls (Fig. 6). The smaller net, with a $10 \mathrm{~m}$ net mouth opening, was used for faster trawl attempts targeting what were believed to be aggregations of larger fish mainly at dawn. Both nets were fitted to a $24 \mathrm{~mm}$ trawl wire which was paid out to $2.5 \mathrm{x}$ the target fishing depth. Both nets used two Tuberin combi trawl doors of $1750 \mathrm{~kg}$ each. Trawling was undertaken between 2 to 3 knots vessel speed.

The Ákra trawl net was fitted with a multisampler for the first deployment. The first three trawls undertaken at Station 2 (all labelled as Event 7) were made using this apparatus. Damage to the multisampler which occurred during recovery of these first trawls meant that it could not be used in successive trawls. Though specific sampling depths were targeted during all trawls the net mouth remained open for the duration of fishing. Incidental catches made during deployment to and recovery from the target depths could therefore not be avoided. This catch was minimised by a quick recovery speed once the nets had been hauled from the target fishing depth. 
Prior to each trawl, ice-trays for sorting and sample labels were prepared. Each label had a unique number although they were not used in a consecutive order. Upon arrival on deck the cod end was immediately emptied into large plastic tubs. Particularly large or interesting samples and samples in very good-condition were removed for photography and the rest of the catch emptied into large trays of ice (the fish sorting area was open to the deck and ambient air temperature could be high). A small amount of seawater was added to each tray to prevent the samples freezing to the ice. The catch was largely sorted into fish, cephalopod, crustacean, gelatinous zooplankton, and other abundant invertebrate groups.

Fish which could not be immediately identified were photographed and stored in formalin. If a second specimen was available, it was stored in ethanol for later genetic analysis. Juvenile and larval stages of fish and crustaceans were preserved in ethanol. All other fish were identified, measured for total length and standard length and frozen in individual zip-lock bags. Very large fish were stored in black bin liners. Additional head length and pre-anal fin length measurements were taken for grenadiers. All large fish were weighed. Labels were fixed to large fish by tying on a loop of string through the mouth and gill slits. Labels were tied around the mantle-arm join or around an individual arm of large cephalopods. All other frozen samples were stored in individual zip lock bags with labels inserted. Formalin and ethanol-stored samples were contained in individual buckets, jars or bottles, with labels inserted.

Crustaceans were identified and species diversity was recorded before weighing and fixing in bulk. All other invertebrates were sorted into broad categories and weighed and fixed in bulk. Fractions of every group were fixed in formalin and ethanol, respectively, and an attempt was made to ensure that representatives of every putative species were included in each fraction. 
For the first 26 trawls (up to and including trawl 26: station 8, event 13) myctophids were individually labelled and frozen after measuring. From trawl 27 (station 8, event 17) onwards myctophids were individually measured but stored together in one container of ethanol with one sample number per trawl. This decision was made based on a shortage of small bags and time constraints during trawl processing. Between 50 and 200 myctophids (in addition to those measured) were taken from each catch and stored in ethanol for later genetic work. Note that the measured myctophids are likely biased towards the larger individuals in each catch.

Small tissue samples were taken from behind the dorsal fin of a subsample of 382 fish by the South African Institute for Aquatic Biodiversity (SAIAB) and stored in ethanol for genetic analysis. Further samples of tissue of both fish and invertebrates were collected for phylogenetic and population genetics studies. Tissue samples from the mantle or arms were collected from large cephalopods and stored in ethanol for genetic analysis. Crustacean and some cephalopod samples were frozen for stable isotope analysis from trawls 23-25, 31, 35, 37 , and 38 .

Trawls 12 (station 5, event 23), 29 (station 8, event 19) and 40 (station 10, event 29) were recorded in their entirety. All other trawls have a "rest of catch" component labelled, weighed, and split between formalin and ethanol storage. This component is the sieved mixed remains of the catch which were not sorted because of time or logistical constraints. This portion typically represented $0.5-1.5 \mathrm{~kg}$ of the total catch for each trawl. Fish and cephalopod samples were lodged with SAIAB. 
CTD system and Niskin bottles

Conductivity, temperature and pressure data were collected using a SeaBird Electronics SBE 911+ CTD and deck unit, together with an SBE 43 dissolved oxygen sensor and Chelsea Instruments Aquatracka Mk III fluorometer. A 12-way rosette holding twelve 5-litre Niskin bottles was used to collect water samples.

CTD 911+ SBE CTD and deck unit details:

CTD serial no 09P8109-0316

Deck unit serial no 11P8109-0305

Pressure sensor serial no. 53966

Temperature sensor serial no. 4143

Conductivity sensor serial no. 2037

SBE43 dissolved oxygen sensor replaced for station 1398 with serial number 431277

Chelsea instruments Aquatracka Mk III serial number 88/2615/119

12-way rosette with $12 \times 5$-litre bottles (several of these were lost during the cruise and were replaced by older bottles).

The system worked well throughout the cruise and a total of 423 stations were sampled. A number of Niskin bottles were lost during bad weather and had to be replaced. The first six bottles were lost on station 1273 and only 9 bottles were available for station 1274 until more could be assembled from spare parts. After this time bottles 11 and 12 regularly leaked or failed to close. To protect against worn cable, the cable was coiled around the top of the CTD frame several times during the cruise. The CTD termination was re-made after station 1490 .

\section{Lowered ADCP}


A Teledyne RDI Sentinel "moored" ADCP was attached to the CTD frame and deployed as a lowered instrument during the cruise. This system used an old potting compound with the known problem of breaking up with cyclic pressurisation. However, it was discovered that the holding bar of the CTD frame was distorted under the weight of the ADCP and since no alternative method of deployment could be found, the use of this instrument ceased for the rest of the cruise. Stations with lowered ADCP data were as follows:

1215, 1216 - between Reunion and Atlantis

$1342,1343,1344,1345,1346$ - Sapmer transect

$1384,1385,1386,1387,1388,1389$ - Middle of What transect

1390,1391,1392,1393,1394,1395,1396,1397 - STC/SAF transect

Satellite data

Merged sea surface height images and absolute surface velocity estimates were received on a daily basis (data were obtained in real-time from AVISO, http://www.aviso.oceanobs.com/). These provided a low-resolution map of the circulation of the region and proved invaluable in planning the location of sections and "off seamount" surveys. They also allowed tracking of the approximate position of the frontal systems over the SWIR as well as the occurrence of significant eddies and rings within the boundary region between cold and warm waters.

Satellite chlorophyll data were obtained in weekly composite maps from the MODIS satellite.

\section{Sampling operations}

Physical data

Oceanographic measurements 
Measurements were undertaken to build-up a picture of the overall structure of water masses and currents both off and on the SWIR. Continuous observations, including surface salinity, temperature and fluorescence along with hull-mounted ADCP, satellite sea-surface height and absolute current measurements and weekly satellite surface chlorophyll estimates, provided a picture of the large-scale distribution of water masses and surface currents as well as proxies for surface productivity. Over each seamount a short, full-depth, CTD transect was undertaken to measure background density gradients and water mass properties (Table 2). In addition, a 24 hour CTD yo-yo was undertaken at or near the seamount crest, in order to provide details of the tidal cycle, inertial oscillations, internal waves and any short-term periodic flow (Table 2). ADCP surveys were undertaken contiguous to the grid-surveys undertaken for multibeam mapping of the seamounts and split-beam acoustic studies of water column biology (see below; Table 3). Overall, these measurements gave a synoptic picture of the occurrence of phenomena such as isopycnal doming over the target seamounts as well as the possibility of detecting tidally-driven rectification or other small-scale oceanographic features (Pollard \& Read, 2017; Read \& Pollard, 2017). These data were potentially important in interpretation of data obtained through net sampling and acoustic surveys over the target seamount areas.

\section{Multibeam bathymetry}

Accurate maps of each target seamount were a pre-requisite to planning of net sampling as well as providing information on the overall shape and complexity of topography potentially important in the interpretation of oceanographic data. On seamount stations multibeam data were collected along ten line transects with a systematic survey design (length $=10 \mathrm{~nm}$, intertransect spacing $=1 \mathrm{~nm}$; Table 3). Transect orientation was chosen as a compromise between minimised vessel pitch and bubble entrainment on one hand, which was weather dependent, 
and maximised seamount coverage on the other. The centre points of the survey grids were chosen arbitrarily within the above constraints. To allow for timing of other sampling operations on the cruise, survey grids were usually separated into two parallel, interlaced grids of 5 transect lines with a $2 \mathrm{~nm}$ spacing, both parts of the complete grids were usually surveyed within 48 hours. Additional multibeam data were collected while the vessel was underway or completing other operations. Two-dimensional maps of the 6 seamounts are presented in Figures 7-12.

\section{Biological observations}

Acoustics

As with measurements for physical oceanographic studies surveys with the split-beam echosounder systems on the R/V Dr Fridtjof Nansen were aimed at ascertaining the structure of pelagic communities both on and off the SWIR. The EK60 was running and logging data throughout the cruise, providing acoustic data while the vessel was underway as well as during fishing operations and CTD deployments (albeit of low quality). Over the target seamounts of the SWIR, and also two non-seamount stations (one in sub-tropical waters and one in sub-Antarctic waters), multifrequency acoustic data were also collected along ten line transects with the systematic survey design (length $=10 \mathrm{~nm}$, inter-transect spacing $=1 \mathrm{~nm}$; Table 3) as described for the multibeam bathymetry surveys. Acoustic grids were surveyed during daytime only, usually from sunrise to mid-day.

\section{Biological oceanography}

The Deep Chlorophyll Maximum (DCM) and bottle sample depths were identified on the downcast and Niskin bottles were triggered on the upcast. Fluorescence was measured by an AQUAtracka III (Chelsea Technologies Group Ltd). Two Niskin bottles were triggered at 
DCM for POM and phytoplankton purposes. Water was collected from five potential depths, i.e. 1) Surface, 2) Below Surface (normally $20 \mathrm{~m}$ ), 3) Below Surface and above DCM (normally around $40-50 \mathrm{~m}$ ), 4) DCM (can be anywhere from surface to >100 m) and 5) Below DCM (next station below DCM that has a visibly lower fluorescence). Samples were collected for size fractionated chl-a, phytoplankton identification, nutrients and particulate organic matter (POM). Half a litre $(500 \mathrm{ml})$ of water from each of the five (or less depending on the depth of DCM) depths were filtered through a Sartorius filter tower cascade set-up with the following filter paper:

a. Top: $20 \mu \mathrm{m}$ Nylon Net Millipore filter to collect microphytoplankton

b. Middle: $2 \mu \mathrm{m}$ Macherey-Nagel filter to collect nanophytoplankton

c. Bottom: $0.7 \mu \mathrm{m} \mathrm{GF/F} \mathrm{Whatman} \mathrm{filter} \mathrm{to} \mathrm{collect} \mathrm{picophytoplankton}$ The filter papers were sealed in tin foil, labeled and placed in a $-20^{\circ} \mathrm{C}$ freezer for later analyses. A litre of water were collected from the surface and the DCM Niskin bottle, preserved with $2 \%$ Lugols $(20 \mathrm{ml})$ and stored for phytoplankton cell counts.

Nets and trawls

Phytoplankton net

The $80 \mu \mathrm{m}$ ring net was deployed vertically to below the DCM and winched up to the surface at $0.5 \mathrm{~m} \cdot \mathrm{s}^{-1}$. At least three casts were undertaken in day and also at night (Table 2).

\section{Bongo net}

The bongo was deployed to $\sim 200 \mathrm{~m}$ depth and retrieved over $\sim 30 \mathrm{~min}$. A flow meter was mounted inside the mouth of one net and the meter readings before and after each tow, along with the time down, was recorded. Three Bongo net hauls were conducted at day and night at 
each station to avoid diel vertical migration bias (Table 4). Samples from the three day and three night hauls were preserved in different ways (see above).

\section{Multisampler net}

For Stratified/Biogeographic studies the nominal stratified ranges were 250-200, 200-150, 150-100, 100-50 and 50-0 m depths. Single stratified hauls were conducted at all stations during day and night time to avoid diel vertical migration bias (see Table 5 for list of deployments and Appendix B for full list of flow meter readings/deployment times and location).

For DCM studies the fluorescence profile from the CTD cast was used to determine the exact depths at which the nets were triggered, which were as follows: two above DCM, one through DCM, two below DCM (to a maximum of 200m depth). A target of two replicate samples was obtained by day and by night for most sampling stations.

Double-warp fish trawl (Ákra trawl)

The pelagic Ákra trawl was deployed ideally three times at day and three at night. Deployments were at shallow (generally 300-400m depth), intermediate (600-700m depth) and deep (900-1100m) depths, with depths determined by the position of the deep-scattering layers, the depth of the seamount summit or other considerations such as weather conditions (Table 6). In most cases, the Flytetrål 152 MSK x 3200mm was used but for some samples where aggregations of fish were present or where greater mobility of the trawl was required (net deployed close to rugged topography) the smaller net was used. Trawl tows are shown in Fig. 13 along with CTD stations for each seamount. 
Problems and assumptions

Opportunities to sample the SWIR are extremely rare and there have been very limited studies of the pelagic ecosystems of the high seas of the South West Indian Ocean. For this project the sampling design was aimed at reaching a balance between obtaining a synoptic picture of large scale variation in oceanography and spatial distribution and abundance of organisms and communities and also identifying the smaller, seamount-scale, variations in physical and biological parameters. This meant a compromise in terms of the scope for obtaining replicate randomised samples for studies of community ecology both on and off seamount stations. The benefit of this approach, however, was that it established baseline information on the biogeography and species diversity associated with the study region. It also allowed us to identify the large-scale processes affecting species composition, abundance and diversity at a range of spatial scales from the influence of water mass, to localised affects arising from, for example, current-topography interactions on biological communities. Clearly there is great scope for more detailed studies of oceanography within this region and the ecology of water column communities around the seamounts of the SWIR to further explore the findings in the present paper and other work associated with the cruise.

The region of the SWIR sampled is extremely exposed to weather systems moving along the Southern Ocean from west to east. Operational considerations, particularly the impacts of weather on sampling operations and transit times between stations meant that there were variations in the timing or positioning of sampling operations leading to a lack of consistency in position and timing of sampling at a range of scales, both between seamounts and also amongst individual samples taken on seamounts. To some extent, sampling operations, such as net hauls, were determined by physical constraints, such as the depth of the seamount 
summit or flanks and also by biological observations. For example, Ákra trawls were often positioned on the basis of acoustic observations with split-beam echosounders rather than being placed randomly around seamounts at set depth horizons. Such lack of consistency again leads to a synoptic picture of the ecology of the pelagic communities on and off the SWIR and potentially also of the small-scale oceanographic structure associated with individual seamounts. Preliminary examination of oceanographic data between the cruises on the SWIR in 2009 and in 2011 indicate large temporal variation in the oceanography of this region, not really surprising given the occurrence of the very complex frontal systems between sub-tropical and sub-Antarctic waters that lie over the ridge (Read \& Pollard, 2017; Pollard \& Read, 2017).

Any biological sampling using nets and also acoustics is biased towards certain types and size-classes of organisms. For nets, mesh size obviously determines what organisms may be retained (Heino et al., 2011). However, water pressure caused by the flow of water through the net will also force or extrude organisms through the net mesh with tow speed being a particularly important factor in the loss of individuals through this process (Sameoto et al., 2000). Delicate organisms, especially small gelatinous zooplankton, are often partially or completely destroyed in zooplankton nets and therefore not retained or are virtually unrecognisable in catches. Nets, especially fine-meshed phytoplankton or mesozooplankton nets can also become clogged with abundant phytoplankton during blooms or gelatinous zooplankton leading to variation in net retention efficiency between samples (Sameoto et al., 2000). Net avoidance, particularly by larger organisms such as micronektonic or nektonic crustaceans, cephalopods and fish can also be an issue. This depends the size of the net mouth, towing speed and the light conditions (time of day) during which sampling takes place (Sameoto et al., 2000; Heino et al., 2011). Nets also exert a herding effect on animals in 
that fish will avoid the sides of the net even where the mesh is sufficiently large to allow them to swim through, eventually becoming trapped in smaller mesh at the rear end of the net (Heino et al., 2011). Behavioural effects may also affect net catch as some animals will avoid a net whilst others may be attracted to a net especially where it is causing bioluminescence through mechanical impact of organisms in the water column (Heino et al., 2011). Net feeding is another aspect of behaviour that can influence catch (Heino et al., 2011).

The Ákra trawl appeared to be particularly useful for sampling the larger size-fractions of zooplankton, micronekton and nekton with sizes of animals down to $\sim 15 \mathrm{~mm}$ being captured. The macrozooplankton trawl primarily captured small organisms $<5 \mathrm{~mm}$ in size. Overall the $10 \mathrm{~mm}$ size class of zooplankton and micronekton was probably the least effectively sampled. During sampling large cephalopods and some fish were often found on the outer parts of the Ákra trawl, perhaps indicating that they were actually attacking the net or narrowly avoided escape. Similar observations were noted by Heino et al. (2011) for the same equipment in the North Atlantic. Net feeding was also evident for some animals (see Fig. 14). Smaller or delicate organisms were also often heavily damaged in the Ákra trawl meaning that identification of specimens was frequently impaired.

Databases and collections

All of the fish samples from the cruise have been lodged with the South African Institute for Aquatic Biodiversity. Crustacean samples analysed in Letessier et al. (2017) are lodged at the Zoology Museum in Oxford.

\section{Concluding remarks}


The papers published in this issue represent a state change in knowledge of the ecology of the pelagic ecosystems of the South West Indian Ocean. They also provide new information on the interactions between seamounts and the overlying water column. These include observations relevant to understanding small-scale oceanographic phenomena associated with seamounts (e.g. Fig. 15), the influence of water mass and elevated topography on pelagic communities around seamounts and the energetic basis of seamount fisheries. Additionally, geophysical data gathered on the morphology of the target seamounts during both the 2009 (Figs 7-12) and 2011 cruises (the latter not reported here) will advance understanding the biology of seamount ecosystems and also the geological processes influencing seamount generation and subsequent erosion. This work is timely both because of the continuing threat posed to seamount ecosystems by deep-sea fisheries but also because of the high likelihood of seabed massive sulphide mining along mid-ocean ridges in the near future. The management of such human activities require detailed information on the ecology of seamounts so that impacts can be predicted and appropriate mitigation measures taken.

\section{Acknowledgements}

We wish to thank the Master and crew of the EAF Nansen Project RV Fridtjof Nansen cruise 2009410 and the NERC cruise RRS James Cook JC066 for their support during the field work at the Southwest Indian Ridge. We also thank the UK National Marine Facilities staff at NOC for ship board support. Further thanks to the scientists onboard during the two voyages. We also thank Dr Marc Wieland, Dept. of Zoology, University of Oxford for preparation of seamount maps in this paper. This work was funded by the Global Environment Facility Grant through UNDP Project IDGEF3138/PIMS3657 executed by IUCN as the IUCN Seamounts Project FFEM-SWIO-P00917(http://www. 
iucn.org/about/work/programmes/marine/marine_our_work/mar-

ine_governance/gmpp_ocean_governance_projects/seamounts/). It was also supported by NERC Grant NE/F005504/1 Benthic Biodiversity of Seamounts in the Southwest Indian Ocean. Additional funding was provided by the FAO/NORAD EAF Nansen Project and Agulhas and Somali Current LME project. The funders had no roles in the study design, data collection and analysis, decision to publish, or preparation of the manuscript. 


\section{References}

Bach, W., Bannerjee, N.R., Dick, H.J.B. and E.T. Baker (2002) Discovery of ancient and active hydrothermal systems along the ultra-slow spreading Southwest Indian Ridge $10^{\circ}-16^{\circ}$ E. Geochem. Geophys. Geosyst. 3: 10.1029/2001GC000279

Barange, M., Pakhomov, E.A., Perissinotto, R., Froneman, P.W., Verheye, H.M., TauntonClark, J. and M.I. Lucas (1998) Pelagic community structure of the subtropical convergence region south of Africa and in the mid-Atlantic Ocean. Deep-Sea Res. I, 45: $1663-1687$.

Bathmann, U., Priddle, J., TreHguer, P., Lucas, M.I., Hall, J. and J. Parslow 2000 - Plankton ecology and biogeochemistry in the Southern Ocean: a review of Southern Ocean JGOFS. In The Changing Ocean Carbon Cycle: A Midterm Synthesis of the Joint Global Ocean Flux Study International Geosphere * Biosphere Programme Series, 5. Hanson, R.B., Ducklow, H. and J.G. Field (Eds.) Cambridge University Press, Cambridge, pp. 300-337.

Bensch, A., Gianni, M., Grébroval, D., Sanders, J.S. and A.Hjort 2008 - Worldwide review of bottom fisheries in the high seas. FAO Fisheries and Aquaculture Technical Paper No. 522, Food and Agricultural Organisation of the UN, Rome, 145pp.

Boswell, S.M. and D. Smythe-Wright 2002 - The tracer signature of Antarctic Bottom Water and its spread in the Southwest Indian Ocean: Part IFCFC-derived translation rate and topographic control around the Southwest Indian Ridge and the Conrad Rise. DeepSea Res. I 49: 555-573.

Boyer, D.C., Kirchner, C.H., McAllister, M.K., Staby, A. and B.I. Staalesen 2001 - The orange roughy fishery of Namibia: lessons to be learned about managing a developing fishery. S. Afr. J. Mar. Sci. 23: 205-221.

Branch, T.A. 2001 - A review of orange roughy Hoplostethus atlanticus fisheries, estimation methods, biology and stock structure. S. Afr. J. Mar. Sci. 23: 181-203.

Clark, A. M. 1972 - Some crinoids from the Indian Ocean. Bull. Brit. Mus. (Nat. Hist.) 24: 
73-156.

Clark, M.R. and A.A. Rowden 2009 - Effect of deepwater trawling on the macro-invertebrate assemblages of seamounts on the Chatham Rise, New Zealand. Deep-Sea Res. I 56: $1540-1554$.

Clark, M.R., Vinnichenko, V.I., Gordon, J.D.M., Beck-Bulat, G.Z., Kukharev, N.N. and A.F. Kakora 2007 - Large-scale distant-water trawl fisheries on seamounts. In Seamounts: Ecology, Fisheries \& Conservation. Pitcher T.J., Morato, T., Hart, P.J.B., Clark, M.R., Haggan, N. and R.S. Santos (Eds), Fish and Aquatic Resources Series 12, Blackwell Publishing, Oxford, U.K., pp 361-399.

Clarke, M. 2007 - Seamounts and cepahlopods. In Seamounts: Ecology, Fisheries \& Conservation. Pitcher T.J., Morato, T., Hart, P.J.B., Clark, M.R., Haggan, N. and R.S. Santos (Eds), Fish and Aquatic Resources Series 12, Blackwell Publishing, Oxford, U.K., pp 207-229.

Clark, M.R., Rowden, A.A., Schlacher, T., Williams, A., Consalvey, M., Stocks, K.I., Rogers, A.D., O’Hara T.D., White, M., Shank, T.M. and Hall-Spencer J (2010) The ecology of seamounts: structure, function and human impacts. Ann. Rev. Mar. Sci. 2: 253-278.

Collette, B.B. and N.V. Parin 1991 - Shallow-water fishes of Walter's Shoals, Madagascar Ridge. Bull. Mar. Sci. 48: 1-22.

Coogan, L.A., Thompson, G.M., MacLeod, C.J., Dick, H.J.B., Edwards, S.J., Hosford Scheirer A. and T.L. Barry 2004 - A combined basalt and peridotite perspective on 14 million years of melt generation at the Atlantis Bank segment of the Southwest Indian Ridge: evidence for temporal changes in mantle dynamics? Chem. Geol. 207: 13-30. Demopoulos, A.W.J., Smith, C.R. and P.A. Tyler 2003 - Ecology of the deep Indian Ocean floor. In: Ecosystems of the World Volume 28: Ecosystems of the Deep Ocean, Tyler, P.A. (Ed.), Elsevier, Amsterdam. 569 pp. 
Dick, J.H.B., Lin, J. and H. Schouten, H. 2003 - An ultra-slow spreading class of ocean ridge. Nature 426: 405-412.

Findley, K. 2009 - Further information on humpback whales from the South-Western Indian Ocean (Breeding Stock C). International Whaling Commission. Intercessional Meeting on Southern Hemisphere Humpback Whale Assessment Methodology, Seattle 3-6 Feb. 2009. Document SC-F09-SH4. 12pp.

Froneman, P.W., Pakhomov, E.A. and V. Meaton 1998 - Surface distribution of microphytoplankton of the South-West Indian Ocean along a repeat transect between Cape Town and the Prince Edward Islands. Unpublished ms, Rhodes University, $32 \mathrm{pp}$.

Genin, A. 2004 - Bio-physical coupling in the formation of zooplankton and fish aggregations over abrupt topographies. J. Mar. Syst. 50: 3-20.

Genin, A. and J.F. Dower 2007 - Seamount plankton dynamics. In Seamounts: Ecology, Fisheries \& Conservation. Pitcher T.J., Morato, T., Hart, P.J.B., Clark, M.R., Haggan, N. and R.S. Santos (Eds), Fish and Aquatic Resources Series 12, Blackwell Publishing, Oxford, U.K., pp 85-100.

Groeneveld, J.C., Griffiths, C.L. and A.P. Van Dalsen 2006 - A new species of spiny lobster, Palinurus barbarae (Decapoda, Palinuridae) from Walter's Shoals on the Madagascar Ridge. Crustaceana 79: 821-833.

Hall-Spencer, J., Allain, V. and J.H. Fosså 2002 - Trawling damage to Northeast Atlantic ancient coral reefs. Proc. Roy. Soc. Lond. B: Biol. Sci. 269: 507-511.

Holland, K.N. and R.D. Grubbs 2007 - Fish visitors to seamounts: tunas and billfish at seamounts. In Seamounts: Ecology, Fisheries \& Conservation. Pitcher T.J., Morato, T., Hart, P.J.B., Clark, M.R., Haggan, N. and R.S. Santos (Eds), Fish and Aquatic Resources Series 12, Blackwell Publishing, Oxford, U.K., pp 189-201. 
Hyrenbach, K.D., Veit, R.R., Weimerskirch, H., Metzl, N. and G. L. Hunt 2007 - Community structure across a large-scale productivity gradient: Marine bird assemblages of the Southern Indian Ocean. Deep-Sea Res. I 54: 1129-1145.

Kaschner, K. 2007 - Air-breathing visitors to seamounts: marine mammals. In Seamounts: Ecology, Fisheries \& Conservation. Pitcher T.J., Morato, T., Hart, P.J.B., Clark, M.R., Haggan, N. and R.S. Santos (Eds), Fish and Aquatic Resources Series 12, Blackwell Publishing, Oxford, U.K., pp 230-238.

Kensley, B. 1975 - Five species of Jaeropsis from the southern Indian Ocean (Crustacea, Isopoda, Asellota). Ann. S. Afr. Mus. 67: 367-380.

Kensley, B. 1981 - On the zoogeography of southern African decapod Crustacea, with a distributional checklist of the species. Smithsonian Contr. Zool. 338: 64 pp.

Lack, M., Short, K. and A. Willock 2003 - Managing risk and uncertainty in deep-sea fisheries: lessons from Orange Roughy. TRAFFIC Oceania and WWF Endangered Seas Programme. 72pp.

Ligi, M., Bonatti, E., Bortoluzzi, G., Carrara, G., Fabretti, P., Gilod, D., Peyve, A.A., Skolotnev, S., and N. Turko (1999) Bouvet Triple Junction in the South Atlantic: geology and evolution. J. Geophys. Res. 104 (B12): 29,365-29,385.

Lindsey, D., Hunt, J.C., Hashimoto, J., Fujiwara, Y., Fujikura, K., Miyake, H. and S. Tsuchida 2000 - Submersible observations on the deep-sea fauna of the south west Indian Ocean: preliminary results for the mesopelagic and near-bottom communities. JAMAREC J. Deep-Sea Res. 16: 23-33.

Litvinov, F. 2007 - Fish visitors to seamounts: aggregations of large pelagic sharks above seamounts. In Seamounts: Ecology, Fisheries \& Conservation. Pitcher T.J., Morato, T., Hart, P.J.B., Clark, M.R., Haggan, N. and R.S. Santos (Eds), Fish and Aquatic Resources Series 12, Blackwell Publishing, Oxford, U.K., pp 202-206. 
Llido, J., Garçon, V., Lutjeharms, J.R.E. and J. Sudre (2005) Event-scale blooms drive enhanced primary productivity at the subtropical convergence. Geophys. Res. Lett. 32: L15611.

Longhurst, A.R. 1998 - Ecological Geography of the Sea. Academic Press, San Diego. Lutjeharms, J.R.E. 1985 - Location of frontal systems between Africa and Antarctica; some preliminary results. Deep-Sea Res. 32: 1499-1509.

Lutjeharms, J.R.E. and R.C. van Ballegooyen 1988 - The retroflection of the Agulhas Current. J. Phys. Oceanogr. 18: 1570-1583.

Lutjeharms, J.R.E. and H.R. Valentine 1984 - Southern Ocean thermal fronts south of Africa. Deep-Sea Res. 31: 1461-1475.

Lutjeharms, J.R.E., Valentine, H.R. and R.C. van Ballegooyen 1993 - On the Subtropical Convergence in the South Atlantic Ocean. S. Afr. J. Mar. Sci. 89: 552-559.

Lutjeharms, J.R.E., Walters, N.M. and B.R. Allanson 1985 - Oceanic frontal systems and biological enhancement. In Antarctic Nutrient Cycles and Food Webs. Siegfried, W.R., Condy, P.R. and R.M. Laws (Eds.),. Springer-Verlag, Berlin, pp. 11-21.

McDonagh, E.L., Bryden, H.L., King, B.A. and R.J. Sanders 2008 - The circulation of the Indian Ocean at $32^{\circ}$ S. Prog. Oceanogr. 79: 20-36.

Meredith, M.P., Watkins, J.L., Murphy, E.J., Cunningham, N.J., Wood, A.G., Korb, R., Whitehouse, M.J., Thorpe, S.E., and F. Vivier (2003) An anticyclonic circulation above the Northwest Georgia Rise, Southern Ocean. Geophysical Research Letters 30: doi:10.1029/2003GL018039

Morato, T. and M.R. Clark 2007 - Seamount fishes: ecology and life histories. In Seamounts: Ecology, Fisheries \& Conservation. Pitcher T.J., Morato, T., Hart, P.J.B., Clark, M.R., Haggan, N. and R.S. Santos (Eds), Fish and Aquatic Resources Series 12, Blackwell Publishing, Oxford, U.K., pp 170 - 188.

Münch, U., Lalou, C., Halbach, P. and H. Fujimoto 2001 - Relict hydrothermal events along 
the super-slow Southwest Indian spreading ridge near 6356’E-mineralogy, chemistry and chronology of sulfide samples. Chem. Geol. 177: 341-349.

Pitcher, T.J. and C. Bulman 2007 - Raiding the larder: a quantitative evaluation framework and trophic signature for seamount food webs. In Seamounts: Ecology, Fisheries \& Conservation. Pitcher T.J., Morato, T., Hart, P.J.B., Clark, M.R., Haggan, N. and R.S. Santos (Eds), Fish and Aquatic Resources Series 12, Blackwell Publishing, Oxford, U.K., pp 282-295.

Read, J.F., Lucas, M.I., Holley, S.E. and R.T. Pollard 2000 - Phytoplankton, nutrients and hydrography in the frontal zone between the Southwest Indian Subtropical gyre and the Southern Ocean. Deep-Sea Res. I 47: 2341-2368.

Read, J.F. and R.T. Pollard 1993 - Structure and transport of the Antarctic Circumpolar Current and Agulhas Return Current at 40E. J. Geophys. Res. 98: 12281-12295.

Richoux, N.B. and P.W. Froneman 2009 - Plankton trophodynamics at the sub-tropical convergence, Southern Ocean. J. Plankton Res. 31: 1059-1073.

Roark, E.B., Guilderson, T.P., Dunbar, R.B., Fallon, S.J. and D.A. Mucclarone 2009 Extreme longevity in proteinaceous deep-sea corals. Proc. Natl. Acad. Sci. USA 106: 5204-5208.

Roark, E.B., Guilderson, T.P., Dunbar, R.B. and B.L. Ingram 2006 - Radiocarbon based ages and growth rates: Hawaiian deep sea corals. Mar. Ecol. Prog. Ser. 327: 1-14.

Rogers, A.D. 1994 - The biology of seamounts. Adv. Mar. Biol. 30: 305-350.

Rogers, A.D., Baco, A., Griffiths, H.J. and J.M. Hall-Spencer 2007 - Corals on seamounts. In Seamounts: Ecology, Fisheries \& Conservation. Pitcher T.J., Morato, T., Hart, P.J.B., Clark, M.R., Haggan, N. and R.S. Santos (Eds), Fish and Aquatic Resources Series 12, Blackwell Publishing, Oxford, U.K., pp 141-169.

Rogers, A.D., Clark, M.R., Hall-Spencer, J.M. and K.M. Gjerde 2008 - The Science behind 
the Guidelines: A Scientific Guide to the FAO Draft International Guidelines (December 2007) For the Management of Deep-Sea Fisheries in the High Seas and Examples of How the Guidelines May Be Practically Implemented. IUCN, Gland, Switzerland. 39pp.

Romanov, E.V. (Ed.) 2003 - Summary and Review of Soviet and Ukrainian scientific and commercial fishing operations on the deepwater ridges of the Southern Indian Ocean. FAO Fisheries Circular No. 991, 84pp.

Rowden, A.A., Clark, M.R. and I.C. Wright 2005 - Physical characterisation and a biologically focused classification of 'seamounts' in the New Zealand region. N.Z. J. Mar. F.W. Res. 39: 1039-1059.

Santos, M.A., Bolten, A.B., Martins, H.R., Riewald, B. And K.A. Bjorndal 2007 - Airbreathing visitors to seamounts: sea turtles. In Seamounts: Ecology, Fisheries \& Conservation. Pitcher T.J., Morato, T., Hart, P.J.B., Clark, M.R., Haggan, N. and R.S. Santos (Eds), Fish and Aquatic Resources Series 12, Blackwell Publishing, Oxford, U.K., pp 239-244.

Sauter, D., Parson, L., Mendel, V., Rommevaux-Jestin, C., Gomez, O., Briais, A., Mével, C., Tamaki, K. and The FUJI Scientific Team (2002) TOBI sidescan sonar imagery of the very slow-spreading Southwest Indian Ridge: evidence for along-axis magma distribution. Earth Planet. Sci. Lett. 199: 81-95.

SEAFO Scientific Committee 2006 - Report of the SEAFO Scientific Committee 2006. Walvis Bay, Namibia, 59pp.

SEAFO Scientific Committee 2008 - Report of the SEAFO Scientific Committee 2008. Walvis Bay, Namibia, 69pp.

Sell, D.W. and M.S. Evans (1982) A statistical analysis of subsampling and an evaluation of the Folsom plankton splitter. Hydrobiologia 94: 223-230.

Shotton, R. 2006 - Managment of demersal fisheries resources of the Southern Indian Ocean. FAO Fisheries Circular No. 1020, FAO, Rome, Italy, 90pp. 
Simpson, E.S.W. and A.E.F. Heydorn 1965 - Vema Seamount. Nature 207: 249-251.

SIODFA (2013) Two New Benthic Protected Areas Come Into Existence in the Southern Indian Ocean. At - http://www.siodfa.org/news/article/two-new-benthic-protectedareas-come-into-existence-in-the-southern-indian. Accessed 28/11/2016.

Stone, R.P. (2006) Coral habitat in the Aleutian Islands of Alaska: depth distribution, finescale species associations and fisheries interactions. Coral Reefs 25: 229-238

Stone, R.P., and S.K. Shotwell (2007) State of deep coral ecosystems in the Alaska region: Gulf of Alaska, Bering Sea and the Aleutian Islands. In: Lumsden, S.E., Hourigan, T.F., Bruchner, A.W. and G. Dorr (eds.), The state of deep coral ecosystems of the United States. NOAA Tech. Memo. CRCP-3, pp. 65-108.

Sultan, E., Mercier, H. and R.T. Pollard 2007 - An inverse model of the large-scale circulation in the Southern Indian Ocean. Prog. Oceanogr. 74: 71-94.

SWIOFC (2009) South West Indian Ocean Fisheries Commission, Report of the Third Session of the Scientific Committee, Maputo, Mozambique, 16-19 September 2008, $85 \mathrm{pp}$.

Tao, C., Lin, J., Guo, S., Chen, Y.J., Wu, G., Han, X., German, C.R., Yoerger, D.R., Zhou, N., Li, H., Su, X., Zhu, J. and the DY115-19 (Legs 1- 2) and DY115-20 (Legs 4 - 7) Science Parties (2012) First active hydrothermal vents on an ultraslow spreading centre: Southwest Indian Ridge. Geology 40: 47-50.

Tao, C., Li, H., Jin, X., Zhou, J., Wu, T., He, Y., Deng, X., Gu, C., Zhang, G., Liu, W. (2014) Seafloor hydrothermal activity and polymetallic sulfide exploration on the south west Indian Ridge. Chinese Science Bulletin 59: 2266-2276.

Thompson, D.R. 2007 - Air-breathing visitors to seamounts: importance of seamounts to 
seabirds. In Seamounts: Ecology, Fisheries \& Conservation. Pitcher T.J., Morato, T., Hart, P.J.B., Clark, M.R., Haggan, N. and R.S. Santos (Eds), Fish and Aquatic Resources Series 12, Blackwell Publishing, Oxford, U.K., pp 245-251.

Tittensor, D.P., Baco-Taylor, A.R., Brewin, P., Clark, M.R., Consalvey, M., Hall-Spencer, J., Rowden, A.A., Schlacher, T., Stocks, K. and A.D. Rogers 2009 - Predicting global habitat suitability for stony corals on seamounts. J. Biogeogr. 36: 1111-1128.

Van Aken, H., Ridderinkhof, H. and W.P.M. de Ruijter 2004 - North Atlantic deep water in the south-western Indian Ocean. Deep-Sea Res. I 51: 755-776.

Vereshchaka, A.L. 1995 - Macroplankton in the near-bottom layer of continental slopes and seamounts. Deep-Sea Res. I 42: 1639-1668.

Vierros, M., Cresswell, I., Briones, E.E., Rice, J. and J. Ardron 2009 - Global Open Oceans and Deep Seabed (GOODS) - Biogeographic Classification. Paris, UNESCO-IOC. IOC Technical Series, 84: 87pp.

Waller, R., Watling, L., Auster, P. and T. Shank 2007 - Anthropogenic impacts on the Corner Rise Seamounts, north-west Atlantic Ocean. J. Mar. Biol. Ass. U.K. 87: 1075-1076.

Weeks, S.J. and F.A. Shillington 1996 - Phytoplankton pigment distribution and frontal structure in the Subtropical Convergence region south of Africa. Deep-Sea Res. I 43: 739-768.

White, M., Bashmachnikov, I., Arístegui, J. and A. Martins 2007 - Physical processes and seamount productivity. In Seamounts: Ecology, Fisheries \& Conservation. Pitcher T.J., Morato, T., Hart, P.J.B., Clark, M.R., Haggan, N. and R.S. Santos (Eds), Fish and Aquatic Resources Series 12, Blackwell Publishing, Oxford, U.K., pp 65-84.

Whitworth III, T. and W.D. Nowlin Jr. 1987 - Water masses and currents of the Southern Ocean at the Greenwich Meridian. J. Geophys. Res. 92: 6462-6476. 
Tables and Figures

Table 1. Approximate locality of each of the main sampling stations. Seamount station position is taken as that of the shallowest point of the seamount summit. Depth of the seabed around each seamount station is taken as the maximum depth within $10 \mathrm{~km}$ of the $1000 \mathrm{~m}$ contour.

Table 2. CTD and townet stations from which water samples were taken giving the date and time (GMT), Nansen CTD station number, position and depth of the CTD at which the first bottle was fired and the location of the station (* indicates where no tow-nets were taken either due to strong winds or lost cod-ends).

Table 3. Acoustic grid survey positions giving date, time, position of the start of each survey, orientation and spacing of survey tracks. Note, most surveys were completed in two separate legs as a result of time constraints imposed by other operations.

Table 4. Bongo net deployments giving Station location date, position of the net at the start of the deployment and position at the end. Flow meter measurements are also given including the flow meter number at the start of deployment and the meter number at the end. The mesh size of the two nets are given along with the methods of preservation for each sample.

Table 5. Multinet deployments giving the Station number, the date, the start time and stop time and start position and stop position for each of five nets for each deployment. Flow meter measurements are also given including the volume of flow through the net and the flow in / out values and flow ratio. 
Table 6. Åkra trawl deployments are given including the Nansen Akra trawl number, the Station Number, the date, the position at the start of the trawl and the position at the end. $\mathrm{D}=$ Day trawl; $\mathrm{N}=$ Night trawl; Dw = dawn trawl. 
Figure 1. SW Indian Ocean showing the South West Indian Ridge, Madagascar Ridge and other topographic features. Stars $=$ Islands; Triangles $=$ Positions of sampled seamounts $($ ATL $=$ Atlantis Bank; SAP $=$ Sapmer Bank; MOW = Middle of What Seamount $;$ MEL $=$ Melville Bank $;$ COR = Coral Seamount UMR = Un-named Seamount Madagascar Ridge $)$, Circles = Off-Seamount Stations; Lines = CTD Transects. Map generated using GEBCO.

Figure 2 SW Indian Ocean showing the South West Indian Ridge, Madagascar Ridge, other topographic features and major surface water masses and fronts. Stars = Islands; Triangles = Positions of sampled seamounts $(\mathrm{ATL}=$ Atlantis Bank; SAP $=$ Sapmer Bank; MOW = Middle of What Seamount; MEL = Melville Bank; COR = Coral Seamount; UMR = Unnamed Seamount Madagascar Ridge); Circles = Off-Seamount Stations; Red Lines = CTD Transects; Yellow Lines = Major currents; Pale Blue Lines $=$ Fronts. Map generated using GEBCO.

Figure 3. Phytoplankton net being recovered at night 13/11/2009. Photograph AD Rogers.

Figure 4. Multinet being recovered during the day 14/11/2009. Photograph AD Rogers.

Figure 5. Bongo nets lying on deck, 12/12/2009. Photograph S. Gotheil.

Figure 6. Åkra trawl being recovered onto the rear deck on the evening of 14/11/2009. Large animals such as squid and fish were often caught in the outer panels of the net. Photograph AD Rogers. 
Figure 7. 2D map of Atlantis Bank generated by multibeam during RV Fridtjof Nansen cruise 2009 410. C/O Marc Wieland, University of Oxford, Dept. Zoology.

Figure 8. 2D map of Sapmer Bank generated by multibeam during RV Fridtjof Nansen cruise 2009 410. C/O Marc Wieland, University of Oxford, Dept. Zoology.

Figure 9. 2D map of Middle of What Seamount generated by multibeam during RV Fridtjof Nansen cruise 2009 410. C/O Marc Wieland, University of Oxford, Dept. Zoology.

Figure 10. 2D map of Melville Bank generated by multibeam during RV Fridtjof Nansen cruise 2009 410. C/O Marc Wieland, University of Oxford, Dept. Zoology.

Figure 11. 2D map of Coral Seamount generated by multibeam during RV Fridtjof Nansen cruise 2009 410. C/O Marc Wieland, University of Oxford, Dept. Zoology.

Figure 12. 2D map of Un-named seamount, Madagascar Ridge, generated by multibeam during RV Fridtjof Nansen cruise 2009 410. C/O Marc Wieland, University of Oxford, Dept. Zoology.

Figure 13. Composite maps for all seamounts showing positions of CTDs (black circles) and trawls (red lines).

Figure 14. Etmopterus pusillus following recovery in Åkra trawl showing evidence of net feeding on squid. 
Figure 15. Internal wave detected through acoustic reflection of entrained zooplankton / micronekton detected over un-named seamount on the South West Indian Ridge. 
Table 1

\begin{tabular}{|c|c|c|c|}
\hline Name & $\begin{array}{l}\text { Position at } \\
\text { shallowest point }\end{array}$ & Summit depth & Morphology \\
\hline $\begin{array}{l}\text { Off-seamount } \\
\text { Station } 1\end{array}$ & $\begin{array}{l}24^{\circ} 48^{\prime} \mathrm{S} \\
55^{\circ} 49.3^{\prime} \mathrm{E}\end{array}$ & N/A & N/A \\
\hline $\begin{array}{l}\text { Off seamount } \\
\text { Station } 2\end{array}$ & $\begin{array}{l}26^{\circ} 56.6^{\prime} \mathrm{S}, \\
56^{\circ} 14.4^{\prime} \mathrm{E}\end{array}$ & N/A & N/A \\
\hline $\begin{array}{l}\text { Off seamount } \\
\text { Station } 3\end{array}$ & $29^{\circ} \mathrm{S}, 56^{\circ} 34.5^{\prime} \mathrm{E}$ & N/A & N/A \\
\hline $\begin{array}{l}\text { Atlantis Bank } \\
\text { Station } 4\end{array}$ & $\begin{array}{l}32^{\circ} 42.69^{\prime} \mathrm{S}, \\
57^{\circ} 16.69^{\prime} \mathrm{E}\end{array}$ & $690 \mathrm{~m}$ & $\begin{array}{l}\text { Elongate / } \\
\text { irregular }\end{array}$ \\
\hline $\begin{array}{l}\text { Sapmer Bank } \\
\text { Station } 5\end{array}$ & $\begin{array}{l}36^{\circ} 48.00^{\prime} \mathrm{S} \\
52^{\circ} 07.32^{\prime} \mathrm{E}\end{array}$ & $261 \mathrm{~m}$ & Irregular \\
\hline $\begin{array}{l}\text { Middle of What } \\
\text { Seamount } \\
\text { Station } 6 \\
\end{array}$ & $\begin{array}{l}37^{\circ} 57.64^{\prime} \mathrm{S} \\
50^{\circ} 24.67^{\prime} \mathrm{E}\end{array}$ & $876 \mathrm{~m}$ & $\begin{array}{l}\text { Irregular / } \\
\text { elliptical (split) }\end{array}$ \\
\hline CTD Section & $\begin{array}{l}\text { Start: } 39^{\circ} 00^{\prime} \mathrm{S}, \\
49^{\circ} 30^{\prime} \mathrm{E} \\
\text { End: } 41^{\circ} 15^{\prime} \mathrm{S} \\
49^{\circ} 30^{\prime} \mathrm{E}\end{array}$ & N/A & N/A \\
\hline $\begin{array}{l}\text { Off seamount } \\
\text { Station } 7\end{array}$ & $\begin{array}{l}41^{\circ} 30^{\prime} \mathrm{S} \\
49^{\circ} 30^{\prime} \mathrm{E}\end{array}$ & N/A & N/A \\
\hline $\begin{array}{l}\text { Coral Seamount } \\
\text { Station } 8\end{array}$ & $\begin{array}{l}41^{\circ} 24.21^{\prime} \mathrm{S}, \\
42^{\circ} 51.33^{\prime} \mathrm{E}\end{array}$ & $175 \mathrm{~m}$ & $\begin{array}{l}\text { Irregular / } \\
\text { rectangular }\end{array}$ \\
\hline CTD Section & $\begin{array}{l}\text { Start: } 41^{\circ} 12.85^{\prime} \mathrm{S} \\
43^{\circ} 00.05^{\prime} \mathrm{E} \\
\text { End: } 38^{\circ} 44.95^{\prime} \mathrm{S} \\
46^{\circ} 22.97^{\prime} \mathrm{E}\end{array}$ & N/A & N/A \\
\hline $\begin{array}{l}\text { Melville Bank } \\
\text { Station } 9\end{array}$ & $\begin{array}{l}38^{\circ} 28.41^{\prime} \mathrm{S}, \\
46^{\circ} 45.05^{\prime} \mathrm{E}\end{array}$ & $91 \mathrm{~m}$ & $\begin{array}{l}\text { Elongate / } \\
\text { irregular (two } \\
\text { peaks) }\end{array}$ \\
\hline $\begin{array}{l}\text { Un-named } \\
\text { Seamount } \\
\text { Station } 10 \\
\end{array}$ & $\begin{array}{l}31^{\circ} 37.86^{\prime} \mathrm{S} \\
42^{\circ} 49.85^{\prime} \mathrm{E}\end{array}$ & $1249 \mathrm{~m}$ & Dome-shaped \\
\hline $\begin{array}{l}\text { Off seamount } \\
\text { Station } 11\end{array}$ & $\begin{array}{l}31^{\circ} 59.36^{\prime} \mathrm{S} \\
41^{\circ} 01.75^{\prime} \mathrm{E}\end{array}$ & N/A & N/A \\
\hline
\end{tabular}


Table 2. CTD and phytoplankton tow-net stations (* indicates where no tow-nets were taken either due to strong winds or lost cod-ends)

\begin{tabular}{|c|c|c|c|c|c|c|c|}
\hline \multirow{2}{*}{$\begin{array}{l}\text { Sample } \\
\text { CTD } \\
\text { No. } \\
\end{array}$} & \multirow{2}{*}{$\begin{array}{l}\text { Nansen } \\
\text { Stn No. }\end{array}$} & \multirow[t]{2}{*}{ Date } & \multirow[t]{2}{*}{ Time } & \multicolumn{2}{|l|}{ Position } & \multirow{2}{*}{$\begin{array}{l}\text { Depth of } \\
\text { bottle } 1 \\
\text { (m) }\end{array}$} & \multirow[t]{2}{*}{ Type } \\
\hline & & & & Latitude & Longitude & & \\
\hline 1 & 1214 & $13 / 11 / 09$ & 14.15 & $24^{\circ} 48.12^{\prime} \mathrm{S}$ & $055^{\circ} 49.41^{\prime} \mathrm{E}$ & 1500 & Off Seamount \\
\hline 2 & 1215 & $14 / 11 / 09$ & 10.08 & $26^{\circ} 56.49^{\prime} \mathrm{S}$ & $056^{\circ} 14.32^{\prime} \mathrm{E}$ & 2003 & Off Seamount \\
\hline 3 & 1216 & 16/11/09 & 02.18 & $29^{\circ} 00.06^{\prime} \mathrm{S}$ & $056^{\circ} 34.57^{\prime} \mathrm{E}$ & 2003 & Off Seamount \\
\hline 4 & 1217 & 17/11/09 & 08.24 & $32^{\circ} 42.87^{\prime} \mathrm{S}$ & $057^{\circ} 17.84^{\prime} \mathrm{E}$ & 700 & Atlantis Seamount \\
\hline 5 & 1225 & 17/11/09 & 18.58 & $32^{\circ} 42.68^{\prime} \mathrm{S}$ & $057^{\circ} 16.29^{\prime} \mathrm{E}$ & 737 & Atlantis Yo-Yo \\
\hline 6 & 1239 & $18 / 11 / 09$ & 01.26 & $32^{\circ} 42.7^{\prime} \mathrm{S}$ & $057^{\circ} 16.26^{\prime} \mathrm{E}$ & 730 & Atlantis Yo-Yo \\
\hline 7 & 1251 & $18 / 11 / 09$ & 07.39 & $32^{\circ} 42.68^{\prime} \mathrm{S}$ & $057^{\circ} 16.30^{\prime} \mathrm{E}$ & 738 & Atlantis Yo-Yo \\
\hline 8 & 1258 & 18/11/09 & 14.28 & $32^{\circ} 42.67^{\prime} \mathrm{S}$ & $057^{\circ} 16.24^{\prime} \mathrm{E}$ & 739 & Atlantis Yo-Yo \\
\hline 9 & 1269 & $19 / 11 / 09$ & 13.07 & $32^{\circ} 40.06^{\prime} \mathrm{S}$ & $057^{\circ} 19.66^{\prime} \mathrm{E}$ & 1638 & Atlantis Transect \\
\hline 10 & 1270 & 19/11/09 & 15.03 & $32^{\circ} 41.40^{\prime} \mathrm{S}$ & 057o18.13’E & 878 & Atlantis Transect \\
\hline 11 & $1271^{*}$ & 19/11/09 & 16.19 & $32^{\circ} 42.01^{\prime} \mathrm{S}$ & $057^{\circ} 17.26^{\prime} \mathrm{E}$ & 712 & Atlantis Transect \\
\hline 12 & 1272 & 19/11/09 & 17.19 & $32^{\circ} 43.28^{\prime} \mathrm{S}$ & $057^{\circ} 15.89^{\prime} \mathrm{E}$ & 715 & Atlantis Transect \\
\hline 13 & 1273 & $19 / 11 / 09$ & 18.18 & $32^{\circ} 43.88^{\prime} \mathrm{S}$ & $057^{\circ} 15.22^{\prime} \mathrm{E}$ & $\begin{array}{r}999 \\
\text { (Bottle 2) } \\
\end{array}$ & Atlantis Transect \\
\hline 14 & 1274 & $19 / 11 / 09$ & 19.35 & $32^{\circ} 44.72^{\prime} \mathrm{S}$ & $057^{\circ} 14.11^{\prime} \mathrm{E}$ & 2051 & Atlantis Transect \\
\hline 15 & 1275 & 21/11/09 & 20.27 & $36^{\circ} 50.87^{\prime} \mathrm{S}$ & $052^{\circ} 04.88^{\prime} \mathrm{E}$ & 542 & Sapmer Seamount \\
\hline 16 & 1276 & $22 / 11 / 09$ & 15.02 & $36^{\circ} 50.59^{\prime} \mathrm{S}$ & $052^{\circ} 08.48^{\prime} \mathrm{E}$ & 510 & Sapmer Yo-Yo \\
\hline 17 & 1287 & $22 / 11 / 09$ & 19.45 & $36^{\circ} 50.60^{\prime} \mathrm{S}$ & $052^{\circ} 08.51^{\prime} \mathrm{E}$ & 508 & Sapmer Yo-Yo \\
\hline 18 & 1305 & 23/11/09 & 02.42 & $36^{\circ} 50.63 \mathrm{~S}$ & $052^{\circ} 08.53^{\prime} \mathrm{E}$ & 509 & Sapmer Yo-Yo \\
\hline 19 & 1322 & 23/11/09 & 08.36 & $36^{\circ} 50.60^{\prime} \mathrm{S}$ & $052^{\circ} 08.52^{\prime} \mathrm{E}$ & 511 & Sapmer Yo-Yo \\
\hline 20 & 1340 & $23 / 11 / 09$ & 14.37 & $36^{\circ} 50.58 \mathrm{~S}$ & $052^{\circ} 08.50 \mathrm{E}$ & 508 & Sapmer Yo-Yo \\
\hline 21 & $1341^{*}$ & $24 / 11 / 09$ & 10.43 & $36^{\circ} 52.18^{\prime} \mathrm{S}$ & $052^{\circ} 10.42^{\prime} \mathrm{E}$ & 1985 & Sapmer Transect \\
\hline 22 & 1342 & 24/11/09 & 12.31 & $36^{\circ} 51.23^{\prime} \mathrm{S}$ & $052^{\circ} 09.13^{\prime} \mathrm{E}$ & 879 & Sapmer Transect \\
\hline 23 & 1343 & $24 / 11 / 09$ & 13.42 & $36^{\circ} 49.63^{\prime} \mathrm{S}$ & $052^{\circ} 07.24^{\prime} \mathrm{E}$ & 441 & Sapmer Transect \\
\hline 24 & 1344 & $24 / 11 / 09$ & 14.24 & $36^{\circ} 48.96^{\prime} \mathrm{S}$ & $052^{\circ} 06.39^{\prime} \mathrm{E}$ & 328 & Sapmer Transect \\
\hline 25 & 1345 & 24/11/09 & 15.03 & $36^{\circ} 48.17^{\prime} \mathrm{S}$ & $052^{\circ} 05.37^{\prime} \mathrm{E}$ & 960 & Sapmer Transect \\
\hline 26 & 1346 & 24/11/09 & 16.08 & $36^{\circ} 46.63$ 'S & $052^{\circ} 03.46^{\prime} \mathrm{E}$ & 2002 & Sapmer Transect \\
\hline 27 & 1347 & $25 / 11 / 09$ & 13.41 & $37^{\circ} 57.56^{\prime} \mathrm{S}$ & $050^{\circ} 24.79^{\prime} \mathrm{E}$ & 301 & MOW Seamount \\
\hline 28 & 1348 & $26 / 11 / 09$ & 02.49 & $37^{\circ} 57.42^{\prime} \mathrm{S}$ & $050^{\circ} 24.83^{\prime} \mathrm{E}$ & 960 & $\begin{array}{l}\text { MOW } \\
\text { Yo-Yo }\end{array}$ \\
\hline
\end{tabular}




\begin{tabular}{|c|c|c|c|c|c|c|c|}
\hline 29 & 1356 & $26 / 11 / 09$ & 08.17 & $37^{\circ} 57.43^{\prime} \mathrm{S}$ & $050^{\circ} 24.80^{\prime} \mathrm{E}$ & 962 & $\begin{array}{l}\text { MOW } \\
\text { Yo-Yo }\end{array}$ \\
\hline 30 & 1363 & $26 / 11 / 09$ & 14.44 & $37^{\circ} 57.45^{\prime} \mathrm{S}$ & $050^{\circ} 24.84^{\prime} \mathrm{E}$ & 960 & $\begin{array}{l}\text { MOW } \\
\text { Yo-Yo }\end{array}$ \\
\hline 31 & 1372 & $26 / 11 / 09$ & 20.20 & $37^{\circ} 57.41^{\prime} \mathrm{S}$ & $050^{\circ} 24.86^{\prime} \mathrm{E}$ & 970 & $\begin{array}{l}\text { MOW } \\
\text { Yo-Yo }\end{array}$ \\
\hline 32 & 1383 & $27 / 11 / 09$ & 02.39 & $37^{\circ} 57.44^{\prime} S$ & $050^{\circ} 24.87^{\prime} \mathrm{E}$ & 960 & $\begin{array}{l}\text { MOW } \\
\text { Yo-Yo }\end{array}$ \\
\hline 33 & $1384^{*}$ & $27 / 11 / 09$ & 16.23 & $37^{\circ} 55.98^{\prime} \mathrm{S}$ & $050^{\circ} 22.42^{\prime} \mathrm{E}$ & 1481 & MOW Transect \\
\hline 34 & $1385^{*}$ & $27 / 11 / 09$ & 17.41 & $37^{\circ} 57.07^{\prime} \mathrm{S}$ & $050^{\circ} 23.88^{\prime} \mathrm{E}$ & 1214 & MOW Transect \\
\hline 35 & $1386^{*}$ & $27 / 11 / 09$ & 18.42 & $37^{\circ} 58.09^{\prime} \mathrm{S}$ & $050^{\circ} 25.16^{\prime} \mathrm{E}$ & 1071 & MOW Transect \\
\hline 36 & $1387^{*}$ & $27 / 11 / 09$ & 19.44 & $37^{\circ} 58.57^{\prime} \mathrm{S}$ & $050^{\circ} 25.79^{\prime} \mathrm{E}$ & 1171 & MOW Transect \\
\hline 37 & $1388^{*}$ & $27 / 11 / 09$ & 20.40 & $37^{\circ} 58.95^{\prime} \mathrm{S}$ & $050^{\circ} 26.22^{\prime} \mathrm{E}$ & 1449 & MOW Transect \\
\hline 38 & $1389^{*}$ & $27 / 11 / 09$ & 22.02 & $38^{\circ} 00.01^{\prime} \mathrm{S}$ & $050^{\circ} 27.60^{\prime} \mathrm{E}$ & 1676 & MOW Transect \\
\hline 39 & 1390 & $28 / 11 / 09$ & 05.30 & $38^{\circ} 59.84^{\prime} \mathrm{S}$ & $050^{\circ} 10.95^{\prime} \mathrm{E}$ & 2001 & CTD Section 1 \\
\hline 40 & 1391 & $28 / 11 / 09$ & 08.37 & $39^{\circ} 15.02^{\prime} \mathrm{S}$ & $050^{\circ} 07.48^{\prime} \mathrm{E}$ & 2002 & CTD Section 1 \\
\hline 41 & 1392 & $28 / 11 / 09$ & 11.40 & $39^{\circ} 30.13^{\prime} \mathrm{S}$ & $050^{\circ} 03.45^{\prime} \mathrm{E}$ & 2001 & CTD Section 1 \\
\hline 42 & 1393 & $28 / 11 / 09$ & 14.51 & $39^{\circ} 45.01^{\prime} \mathrm{S}$ & $049^{\circ} 59.56^{\prime} \mathrm{E}$ & 2002 & CTD Section 1 \\
\hline 43 & 1394 & $28 / 11 / 09$ & 18.00 & $40^{\circ} 00.02^{\prime} \mathrm{S}$ & $049^{\circ} 55.58^{\prime} \mathrm{E}$ & 2001 & CTD Section 1 \\
\hline 44 & 1395 & $28 / 11 / 09$ & 20.51 & $40^{\circ} 15.09^{\prime} \mathrm{S}$ & $049^{\circ} 51.62^{\prime} \mathrm{E}$ & 2001 & CTD Section 1 \\
\hline 45 & 1396 & $28 / 11 / 09$ & 23.55 & $40^{\circ} 30.10^{\prime} \mathrm{S}$ & $049^{\circ} 47.45^{\prime} \mathrm{E}$ & 2002 & CTD Section 1 \\
\hline 46 & 1397 & $29 / 11 / 09$ & 03.05 & $40^{\circ} 44.96^{\prime} \mathrm{S}$ & $049^{\circ} 43.14^{\prime} \mathrm{E}$ & 2004 & CTD Section 1 \\
\hline 47 & 1398 & $29 / 11 / 09$ & 06.01 & $40^{\circ} 59.65^{\prime} \mathrm{S}$ & $049^{\circ} 38.82^{\prime} \mathrm{E}$ & 2002 & CTD Section 1 \\
\hline 48 & 1399 & $29 / 11 / 09$ & 09.05 & $41^{\circ} 14.83^{\prime} \mathrm{S}$ & $049^{\circ} 34.53^{\prime} \mathrm{E}$ & 2001 & CTD Section 1 \\
\hline 49 & 1400 & $29 / 11 / 09$ & 12.11 & $41^{\circ} 30.00^{\prime} \mathrm{S}$ & $049^{\circ} 30.04^{\prime} \mathrm{E}$ & 2001 & CTD Section 1 \\
\hline 50 & 1401 & $01 / 12 / 09$ & 22.45 & $41^{\circ} 25.44^{\prime} \mathrm{S}$ & $042^{\circ} 50.82^{\prime} \mathrm{E}$ & 303 & Coral Seamount \\
\hline 51 & 1402 & $03 / 12 / 09$ & 02.58 & $41^{\circ} 25.35^{\prime} \mathrm{S}$ & $042^{\circ} 50.69^{\prime} \mathrm{E}$ & 802 & $\begin{array}{l}\text { Coral } \\
\text { Yo-Yo }\end{array}$ \\
\hline 52 & 1422 & $03 / 12 / 09$ & 08.41 & $41^{\circ} 25.27^{\prime} \mathrm{S}$ & $042^{\circ} 51.24^{\prime} \mathrm{E}$ & 407 & $\begin{array}{l}\text { Coral } \\
\text { Yo-Yo }\end{array}$ \\
\hline 53 & 1443 & $03 / 12 / 09$ & 14.34 & $41^{\circ} 25.27^{\prime} \mathrm{S}$ & $042^{\circ} 51.19^{\prime} \mathrm{E}$ & 405 & $\begin{array}{l}\text { Coral } \\
\text { Yo-Yo }\end{array}$ \\
\hline 54 & 1466 & $03 / 12 / 09$ & 20.45 & $41^{\circ} 25.29^{\prime} \mathrm{S}$ & $042^{\circ} 51.21^{\prime} \mathrm{E}$ & 400 & $\begin{array}{l}\text { Coral } \\
\text { Yo-Yo }\end{array}$ \\
\hline 55 & 1488 & $04 / 12 / 09$ & 02.19 & $41^{\circ} 25.27^{\prime} \mathrm{S}$ & $042^{\circ} 51.21^{\prime} \mathrm{E}$ & 402 & $\begin{array}{l}\text { Coral } \\
\text { Yo-Yo }\end{array}$ \\
\hline 56 & 1490 & $04 / 12 / 09$ & 10.29 & $41^{\circ} 29.13^{\prime} \mathrm{S}$ & $042^{\circ} 54.01^{\prime} \mathrm{E}$ & 1557 & Coral Transect \\
\hline 57 & 1492 & $04 / 12 / 09$ & 14.21 & $41^{\circ} 25.71^{\prime} \mathrm{S}$ & $042^{\circ} 52.51^{\prime} \mathrm{E}$ & 566 & Coral Transect \\
\hline 58 & $1493 *$ & $04 / 12 / 09$ & 15.47 & $41^{\circ} 24.28^{\prime} \mathrm{S}$ & $042^{\circ} 51.67^{\prime} \mathrm{E}$ & 191 & Coral Transect \\
\hline
\end{tabular}




\begin{tabular}{|c|c|c|c|c|c|c|c|}
\hline & & & & & & & \\
\hline 59 & 1494* & $04 / 12 / 09$ & 16.21 & $41^{\circ} 23.50^{\prime} \mathrm{S}$ & $042^{\circ} 51.26^{\prime} \mathrm{E}$ & 902 & Coral Transect \\
\hline 60 & $1495^{*}$ & $04 / 12 / 09$ & 17.23 & $41^{\circ} 21.23^{\prime} \mathrm{S}$ & $042^{\circ} 50.30^{\prime} \mathrm{E}$ & 1870 & Coral Transect \\
\hline 61 & $1496 *$ & $04 / 12 / 09$ & 19.40 & $41^{\circ} 12.18^{\prime} \mathrm{S}$ & $043^{\circ} 00.05^{\prime} \mathrm{E}$ & 1573 & CTD Section 2 \\
\hline 62 & $1497 *$ & $04 / 12 / 09$ & 22.31 & $40^{\circ} 59.95^{\prime} \mathrm{S}$ & $043^{\circ} 12.34^{\prime} \mathrm{E}$ & 2003 & CTD Section 2 \\
\hline 63 & $1498 *$ & $05 / 12 / 09$ & 01.36 & $40^{\circ} 48.02^{\prime} \mathrm{S}$ & $043^{\circ} 35.03^{\prime} \mathrm{E}$ & 2003 & CTD Section 2 \\
\hline 64 & 1499 & $05 / 12 / 09$ & 04.49 & $40^{\circ} 36.09^{\prime} \mathrm{S}$ & $043^{\circ} 51.98^{\prime} \mathrm{E}$ & 2002 & CTD Section 2 \\
\hline 65 & 1500 & $05 / 12 / 09$ & 08.16 & $40^{\circ} 23.98^{\prime} \mathrm{S}$ & $044^{\circ} 08.93^{\prime} \mathrm{E}$ & 2001 & CTD Section 2 \\
\hline 66 & 1501 & $05 / 12 / 09$ & 11.30 & $40^{\circ} 12.13^{\prime} \mathrm{S}$ & $044^{\circ} 25.63^{\prime} \mathrm{E}$ & 2003 & CTD Section 2 \\
\hline 67 & 1502 & $05 / 12 / 09$ & 14.48 & $40^{\circ} 00.03^{\prime} \mathrm{S}$ & $044^{\circ} 41.85^{\prime} \mathrm{E}$ & 2004 & CTD Section 2 \\
\hline 68 & 1503 & $05 / 12 / 09$ & 18.03 & $39^{\circ} 48.06^{\prime} \mathrm{S}$ & $044^{\circ} 58.37^{\prime} \mathrm{E}$ & 2001 & CTD Section 2 \\
\hline 69 & 1504 & $05 / 12 / 09$ & 21.18 & $39^{\circ} 36.00^{\prime} \mathrm{S}$ & $045^{\circ} 15.04^{\prime} \mathrm{E}$ & 2003 & CTD Section 2 \\
\hline 70 & 1505 & $06 / 12 / 09$ & 00.48 & $39^{\circ} 23.97^{\prime} \mathrm{S}$ & $045^{\circ} 31.16^{\prime} \mathrm{E}$ & 2002 & CTD Section 2 \\
\hline 71 & 1506 & $06 / 12 / 09$ & 04.02 & $39^{\circ} 11.96^{\prime} \mathrm{S}$ & $045^{\circ} 47.40^{\prime} \mathrm{E}$ & 2000 & CTD Section 2 \\
\hline 72 & 1507 & $06 / 12 / 09$ & 07.23 & $38^{\circ} 55.99^{\prime} \mathrm{S}$ & $046^{\circ} 03.53^{\prime} \mathrm{E}$ & 2002 & CTD Section 2 \\
\hline 73 & 1508 & $06 / 12 / 09$ & 10.55 & $38^{\circ} 44.95^{\prime} \mathrm{S}$ & $046^{\circ} 22.97^{\prime} \mathrm{E}$ & 2003 & CTD Section 2 \\
\hline 74 & 1509 & $06 / 12 / 09$ & 14.56 & $38^{\circ} 31.56^{\prime} \mathrm{S}$ & $046^{\circ} 45.74^{\prime} \mathrm{E}$ & 1862 & Melville Transect 1 \\
\hline 75 & 1510 & $06 / 12 / 09$ & 16.28 & $38^{\circ} 30.17^{\prime} \mathrm{S}$ & $046^{\circ} 45.32^{\prime} \mathrm{E}$ & 1063 & Melville Transect 1 \\
\hline 76 & 1511 & $06 / 12 / 09$ & 17.47 & $38^{\circ} 29.23^{\prime} \mathrm{S}$ & $046^{\circ} 44.98^{\prime} \mathrm{E}$ & 512 & Melville Transect 1 \\
\hline 77 & 1512 & $06 / 12 / 09$ & 18.57 & $38^{\circ} 28.68^{\prime} \mathrm{S}$ & $046^{\circ} 44.75^{\prime} \mathrm{E}$ & 361 & Melville Transect 1 \\
\hline 78 & 1513 & $06 / 12 / 09$ & 19.59 & $38^{\circ} 28.29^{\prime} \mathrm{S}$ & $046^{\circ} 44.67^{\prime} \mathrm{E}$ & 101 & Melville Transect 1 \\
\hline 79 & 1514 & $06 / 12 / 09$ & 20.39 & $38^{\circ} 27.83^{\prime} \mathrm{S}$ & $046^{\circ} 44.42^{\prime} \mathrm{E}$ & 852 & Melville Transect 1 \\
\hline 80 & 1515 & $06 / 12 / 09$ & 21.50 & $38^{\circ} 26.81^{\prime} \mathrm{S}$ & $046^{\circ} 44.03^{\prime} \mathrm{E}$ & 1681 & Melville Transect 1 \\
\hline 81 & 1516 & $08 / 12 / 09$ & 18.52 & $38^{\circ} 28.38^{\prime} \mathrm{S}$ & $046^{\circ} 48.45^{\prime} \mathrm{E}$ & 1258 & Melville Transect 2 \\
\hline 82 & 1517 & $08 / 12 / 09$ & 19.57 & $38^{\circ} 28.51^{\prime} \mathrm{S}$ & $046^{\circ} 47.57^{\prime} \mathrm{E}$ & 751 & Melville Transect 2 \\
\hline 83 & 1518 & $08 / 12 / 09$ & 20.42 & $38^{\circ} 28.36^{\prime} \mathrm{S}$ & $046^{\circ} 46.85^{\prime} \mathrm{E}$ & 550 & Melville Transect 2 \\
\hline 84 & 1519 & $08 / 12 / 09$ & 21.34 & $38^{\circ} 28.24^{\prime} \mathrm{S}$ & $046^{\circ} 45.47^{\prime} \mathrm{E}$ & 106 & Melville Transect 2 \\
\hline 85 & 1520 & $08 / 12 / 09$ & 22.02 & $38^{\circ} 28.27^{\prime} \mathrm{S}$ & $046^{\circ} 44.60^{\prime} \mathrm{E}$ & 109 & Melville Transect 2 \\
\hline 86 & 1521 & $08 / 12 / 09$ & 22.33 & $38^{\circ} 28.33^{\prime} \mathrm{S}$ & $046^{\circ} 43.78^{\prime} \mathrm{E}$ & 550 & Melville Transect 2 \\
\hline 87 & 1522 & $08 / 12 / 09$ & 23.16 & $38^{\circ} 28.67^{\prime} \mathrm{S}$ & $046^{\circ} 42.80^{\prime} \mathrm{E}$ & 420 & Melville Transect 2 \\
\hline
\end{tabular}




\begin{tabular}{|c|c|c|c|c|c|c|c|}
\hline 88 & 1523 & 08/12/09 & 23.53 & $38^{\circ} 28.66^{\prime} \mathrm{S}$ & $046^{\circ} 42.32^{\prime} \mathrm{E}$ & 430 & Melville Transect 2 \\
\hline 89 & 1524 & $08 / 12 / 09$ & 00.37 & $38^{\circ} 28.33^{\prime} \mathrm{S}$ & $046^{\circ} 41.25^{\prime} \mathrm{E}$ & 1052 & Melville Transect 2 \\
\hline 90 & 1525 & 08/12/09 & 01.39 & $38^{\circ} 28.07^{\prime} \mathrm{S}$ & $046^{\circ} 40.60^{\prime} \mathrm{E}$ & 1350 & Melville Transect 2 \\
\hline 91 & 1526 & $09 / 12 / 09$ & 09.54 & $38^{\circ} 28.26^{\prime} \mathrm{S}$ & $046^{\circ} 43.92^{\prime} \mathrm{E}$ & 505 & Melville Yo-Yo \\
\hline 92 & 1545 & $09 / 12 / 09$ & 15.54 & $38^{\circ} 28.26^{\prime} \mathrm{S}$ & $046^{\circ} 43.93^{\prime} \mathrm{E}$ & 507 & Melville Yo-Yo \\
\hline 93 & 1563 & 09/12/09 & 21.38 & $38^{\circ} 28.28^{\prime} \mathrm{S}$ & $046^{\circ} 43.91^{\prime} \mathrm{E}$ & 510 & Melville Yo-Yo \\
\hline 94 & 1582 & $10 / 12 / 09$ & 03.39 & $38^{\circ} 28.28^{\prime} \mathrm{S}$ & $046^{\circ} 43.96^{\prime} \mathrm{E}$ & 500 & Melville Yo-Yo \\
\hline 95 & 1600 & $10 / 12 / 09$ & 09.34 & $38^{\circ} 28.26^{\prime} \mathrm{S}$ & $046^{\circ} 43.94^{\prime} \mathrm{E}$ & 507 & Melville Yo-Yo \\
\hline 96 & 1601 & $12 / 12 / 09$ & 16.24 & $31^{\circ} 34.33^{\prime} \mathrm{S}$ & $042^{\circ} 45.78^{\prime} \mathrm{E}$ & 301 & Madagascar Ridge \\
\hline 97 & 1602 & $13 / 12 / 09$ & 13.06 & $31^{\circ} 37.34^{\prime} \mathrm{S}$ & $042^{\circ} 49.17^{\prime} \mathrm{E}$ & 1252 & $\begin{array}{l}\text { Madagascar Ridge } \\
\text { Yo-Yo }\end{array}$ \\
\hline 98 & 1611 & $13 / 12 / 09$ & 20.08 & $31^{\circ} 37.34^{\prime} S$ & $042^{\circ} 49.19^{\prime} \mathrm{E}$ & 1249 & $\begin{array}{l}\text { Madagascar Ridge } \\
\text { Yo-Yo }\end{array}$ \\
\hline 99 & 1618 & $14 / 12 / 09$ & 01.49 & $31^{\circ} 37.42^{\prime} \mathrm{S}$ & $042^{\circ} 49.13^{\prime} \mathrm{E}$ & 1256 & $\begin{array}{l}\text { Madagascar Ridge } \\
\text { Yo-Yo }\end{array}$ \\
\hline 100 & 1624 & $14 / 12 / 09$ & 07.19 & $31^{\circ} 37.33^{\prime} \mathrm{S}$ & $042^{\circ} 49.39^{\prime} \mathrm{E}$ & 1251 & $\begin{array}{l}\text { Madagascar Ridge } \\
\text { Yo-Yo }\end{array}$ \\
\hline 101 & 1628 & $14 / 12 / 09$ & 11.37 & $31^{\circ} 37.37^{\prime} \mathrm{S}$ & $042^{\circ} 49.17^{\prime} \mathrm{E}$ & 1257 & $\begin{array}{l}\text { Madagascar Ridge } \\
\text { Yo-Yo }\end{array}$ \\
\hline 102 & 1629 & $14 / 12 / 09$ & 16.49 & $31^{\circ} 41.82^{\prime} \mathrm{S}$ & $042^{\circ} 54.72^{\prime} \mathrm{E}$ & 1702 & $\begin{array}{l}\text { Madagascar Ridge } \\
\text { Transect }\end{array}$ \\
\hline 103 & $1630^{*}$ & $14 / 12 / 09$ & 18.28 & $31^{\circ} 40.40^{\prime} \mathrm{S}$ & $042^{\circ} 52.90^{\prime} \mathrm{E}$ & 1444 & $\begin{array}{l}\text { Madagascar Ridge } \\
\text { Transect }\end{array}$ \\
\hline 104 & $1631 *$ & $14 / 12 / 09$ & 19.48 & $31^{\circ} 38.69^{\prime} \mathrm{S}$ & $042^{\circ} 50.93^{\prime} \mathrm{E}$ & 1330 & $\begin{array}{l}\text { Madagascar Ridge } \\
\text { Transect }\end{array}$ \\
\hline 105 & $1632 *$ & $14 / 12 / 09$ & 20.53 & $31^{\circ} 37.35^{\prime} \mathrm{S}$ & $042^{\circ} 49.15^{\prime} \mathrm{E}$ & 1261 & $\begin{array}{l}\text { Madagascar Ridge } \\
\text { Transect }\end{array}$ \\
\hline 106 & $1633^{*}$ & $14 / 12 / 09$ & 21.53 & $31^{\circ} 35.90^{\prime} \mathrm{S}$ & $042^{\circ} 47.53^{\prime} \mathrm{E}$ & 1354 & $\begin{array}{l}\text { Madagascar Ridge } \\
\text { Transect }\end{array}$ \\
\hline 107 & $1634^{*}$ & $14 / 12 / 09$ & ? & $31^{\circ} 34.53^{\prime} \mathrm{S}$ & $042^{\circ} 45.96^{\prime} \mathrm{E}$ & 1469 & $\begin{array}{l}\text { Madagascar Ridge } \\
\text { Transect }\end{array}$ \\
\hline 108 & $1635^{*}$ & $15 / 12 / 09$ & 00.07 & $31^{\circ} 33.07^{\prime} \mathrm{S}$ & $042^{\circ} 44.32^{\prime} \mathrm{E}$ & 1887 & $\begin{array}{l}\text { Madagascar Ridge } \\
\text { Transect }\end{array}$ \\
\hline 109 & 1636 & $15 / 12 / 09$ & 10.04 & $31^{\circ} 59.36^{\prime} \mathrm{S}$ & $041^{\circ} 01.75^{\prime} \mathrm{E}$ & 302 & Off seamount \\
\hline
\end{tabular}


Table 3 Acoustic grid positions

\begin{tabular}{|c|c|c|c|c|c|c|c|c|}
\hline Station & $\begin{array}{l}\text { Date } \\
(2009)\end{array}$ & $\begin{array}{l}\text { Start of } \\
\text { survey } \\
\text { (GMT) }\end{array}$ & $\begin{array}{l}\text { End of } \\
\text { survey } \\
\text { (GMT) }\end{array}$ & $\overline{\text { Lat }}$ & Long & $\begin{array}{l}\begin{array}{l}\text { Orientation } \\
\text { (degrees) }\end{array} \\
\end{array}$ & Transects & $\begin{array}{l}\text { Transect } \\
\text { length } \\
\text { (nautical } \\
\text { miles) }\end{array}$ \\
\hline $\begin{array}{l}02 \text { Off } \\
\text { Ridge }\end{array}$ & $14 / 11$ & $03: 27$ & $09: 26$ & $26^{\circ} 49.36^{\prime} \mathrm{S}$ & $56^{\circ} 14.64^{\prime} \mathrm{E}$ & 315 & 5 & 10 \\
\hline North & $15 / 11$ & $01: 58$ & $07: 53$ & $26^{\circ} 50.32^{\prime} \mathrm{S}$ & $56^{\circ} 15.74^{\prime} \mathrm{E}$ & 315 & 5 & 10 \\
\hline $\begin{array}{l}\text { 04 Atlantis } \\
\text { Bank }\end{array}$ & $\begin{array}{l}17 / 11 \\
19 / 11\end{array}$ & $\begin{array}{l}01: 38 \\
02: 39\end{array}$ & $\begin{array}{l}07: 40 \\
08: 40\end{array}$ & $\begin{array}{l}32^{\circ} 36.12^{\prime} \mathrm{S} \\
32^{\circ} 37.12^{\prime} \mathrm{S}\end{array}$ & $\begin{array}{l}57^{\circ} 17.64^{\prime} \mathrm{E} \\
57^{\circ} 17.35^{\prime} \mathrm{E}\end{array}$ & $\begin{array}{l}315 \\
315\end{array}$ & $\begin{array}{l}5 \\
5\end{array}$ & $\begin{array}{l}10 \\
10\end{array}$ \\
\hline $\begin{array}{l}\text { 05 Sapmer } \\
\text { Bank }\end{array}$ & $\begin{array}{l}22 / 11 \\
24 / 11\end{array}$ & $\begin{array}{l}01: 17 \\
03: 24\end{array}$ & $\begin{array}{l}07: 23 \\
09: 30\end{array}$ & $\begin{array}{l}36^{\circ} 51.14^{\prime} \mathrm{S} \\
36^{\circ} 49.88^{\prime} \mathrm{S}\end{array}$ & $\begin{array}{l}52^{\circ} 15.09^{\prime} \mathrm{E} \\
51^{\circ} 59.23^{\prime} \mathrm{E}\end{array}$ & $\begin{array}{l}315 \\
315\end{array}$ & $\begin{array}{l}5 \\
5\end{array}$ & $\begin{array}{l}10.5 \\
10.5\end{array}$ \\
\hline $\begin{array}{l}06 \text { Middle } \\
\text { of What }\end{array}$ & $\begin{array}{l}25 / 11 \\
27 / 11\end{array}$ & $\begin{array}{l}\text { 06:55 } \\
\text { 04:09 }\end{array}$ & $\begin{array}{l}12: 54 \\
10: 01\end{array}$ & $\begin{array}{l}37^{\circ} 50.76^{\prime} \mathrm{S} \\
37^{\circ} 51.60^{\prime} \mathrm{S}\end{array}$ & $\begin{array}{l}50^{\circ} 23.95^{\prime} \mathrm{E} \\
50^{\circ} 23.95^{\prime} \mathrm{E}\end{array}$ & $\begin{array}{l}315 \\
315\end{array}$ & $\begin{array}{l}5 \\
5\end{array}$ & $\begin{array}{l}10 \\
10\end{array}$ \\
\hline $\begin{array}{l}07 \text { Off- } \\
\text { Ridge } \\
\text { South }\end{array}$ & $30 / 11$ & 01:01 & $11: 38$ & $41^{\circ} 34.34^{\prime} \mathrm{S}$ & $49^{\circ} 37.18^{\prime} \mathrm{E}$ & 350 & 10 & 10 \\
\hline $\begin{array}{l}08 \text { Coral } \\
\text { Seamount }\end{array}$ & $\begin{array}{l}/ 12 \\
4 / 12 \\
\end{array}$ & $\begin{array}{l}02: 07 \\
03: 51\end{array}$ & $\begin{array}{l}\text { 08:04 } \\
\text { 09:44 }\end{array}$ & $\begin{array}{l}41^{\circ} 31.17^{\prime} \mathrm{S} \\
41^{\circ} 21.70^{\prime} \mathrm{S}\end{array}$ & $\begin{array}{l}42^{\circ} 49.81^{\prime} \mathrm{E} \\
42^{\circ} 46.63^{\prime} \mathrm{E}\end{array}$ & $\begin{array}{l}340 \\
340\end{array}$ & $\begin{array}{l}5 \\
5\end{array}$ & $\begin{array}{l}10 \\
10\end{array}$ \\
\hline $\begin{array}{l}\text { 09 Melville } \\
\text { Bank }\end{array}$ & $\begin{array}{l}7 / 12 \\
9 / 12\end{array}$ & $\begin{array}{l}03: 46 \\
02: 51\end{array}$ & $\begin{array}{l}0.16: 15 \\
08: 43\end{array}$ & $\begin{array}{l}38^{\circ} 25.01 \mathrm{~S} \\
38^{\circ} 25.59^{\prime} \mathrm{S}\end{array}$ & $\begin{array}{l}46^{\circ} 37.96^{\prime} \mathrm{E} \\
46^{\circ} 37.22^{\prime} \mathrm{E}\end{array}$ & $\begin{array}{l}345 \\
345\end{array}$ & $\begin{array}{l}5 \\
5\end{array}$ & $\begin{array}{l}10 \\
10\end{array}$ \\
\hline $\begin{array}{l}10 \\
\text { Madagascar } \\
\text { Ridge } \\
\text { Seamount }\end{array}$ & $\begin{array}{l}12 / 12 \\
13 / 12\end{array}$ & $\begin{array}{l}10: 16 \\
02: 42\end{array}$ & $\begin{array}{l}15: 58 \\
08: 23\end{array}$ & $\begin{array}{l}31^{\circ} 38.82^{\prime} \mathrm{S} \\
31^{\circ} 37.89^{\prime} \mathrm{S}\end{array}$ & $\begin{array}{l}42^{\circ} 57.41^{\prime} \mathrm{E} \\
42^{\circ} 57.54^{\prime} \mathrm{E}\end{array}$ & $\begin{array}{l}315 \\
315\end{array}$ & $\begin{array}{l}5 \\
5\end{array}$ & $\begin{array}{l}10 \\
10\end{array}$ \\
\hline
\end{tabular}


Table 4 Bongo net deployments

\begin{tabular}{|c|c|c|c|c|c|c|c|c|c|}
\hline Station & Date & $\begin{array}{l}\text { Start } \\
\text { haul }\end{array}$ & $\begin{array}{l}\text { Stop } \\
\text { haul }\end{array}$ & $\begin{array}{l}\text { Position } \\
\text { start }\end{array}$ & $\begin{array}{l}\text { Position } \\
\text { stop }\end{array}$ & Start flow & $\begin{array}{l}\text { Stop } \\
\text { flow }\end{array}$ & $\begin{array}{l}\text { Mesh } \\
(\mu \mathrm{m})\end{array}$ & Preservation \\
\hline 2 & $\begin{array}{l}15 / 11 / 09 \\
\end{array}$ & 01.53 & 02.27 & $26^{\circ} 50.25^{\prime} \mathrm{S}$ & $26^{\circ} 53.93^{\prime} \mathrm{S}$ & 27173 & 31981 & 375 & Ethanol \\
\hline 2 & $15 / 11 / 09$ & 01.53 & 02.27 & $56^{\circ} 15.79^{\prime} \mathrm{E}$ & $56^{\circ} 11.70^{\prime} \mathrm{E}$ & 4174 & 11066 & 500 & Formalin \\
\hline 2 & $15 / 11 / 09$ & 02.41 & 03.19 & $26^{\circ} 55.69^{\prime} \mathrm{S}$ & $26^{\circ} 57.79^{\prime} \mathrm{S}$ & 31981 & 39100 & 375 & Ethanol \\
\hline 2 & $15 / 11 / 09$ & 02.41 & 03.19 & $56^{\circ} 09.75^{\prime} \mathrm{E}$ & $56^{\circ} 10.50^{\prime} \mathrm{E}$ & 11066 & 20426 & 500 & Formalin \\
\hline 2 & $15 / 11 / 09$ & 03.28 & 04.05 & $26^{\circ} 56.75^{\prime} \mathrm{S}$ & $26^{\circ} 52.58^{\prime} \mathrm{S}$ & 20426 & 28857 & 375 & Ethanol \\
\hline 2 & $15 / 11 / 09$ & 03.28 & 04.05 & $56^{\circ} 11.67^{\prime} \mathrm{E}$ & $56^{\circ} 16.44^{\prime} \mathrm{E}$ & 39100 & 45318 & 500 & Formalin \\
\hline 2 & $15 / 11 / 09$ & 04.12 & 04.55 & $26^{\circ} 52.13^{\prime} \mathrm{S}$ & $26^{\circ} 57.39^{\prime} \mathrm{S}$ & 28857 & 38198 & 375 & Ethanol \\
\hline 2 & $15 / 11 / 09$ & 04.12 & 04.55 & $56^{\circ} 17.37^{\prime} \mathrm{E}$ & $56^{\circ} 14.22^{\prime} \mathrm{E}$ & 45318 & 51886 & 500 & Formalin \\
\hline 2 & $15 / 11 / 09$ & 16.22 & 16.50 & $27^{\circ} 17.74^{\prime} \mathrm{S}$ & $27^{\circ} 22.48^{\prime} \mathrm{S}$ & 38198 & 44362 & 375 & Ethanol \\
\hline 2 & $15 / 11 / 09$ & 16.22 & 16.50 & $56^{\circ} 16.18^{\prime} \mathrm{E}$ & $56^{\circ} 17.11^{\prime} \mathrm{E}$ & 51886 & 56512 & 500 & Formalin \\
\hline 2 & $15 / 11 / 09$ & 16.57 & 17.30 & $27^{\circ} 23.84^{\prime} \mathrm{S}$ & $27^{\circ} 29.48^{\prime} \mathrm{S}$ & 56512 & 60587 & 375 & Ethanol \\
\hline 2 & $15 / 11 / 09$ & 16.57 & 17.30 & $56^{\circ} 17.35^{\prime} \mathrm{E}$ & $56^{\circ} 18.44^{\prime} \mathrm{E}$ & 44362 & 51595 & 500 & Formalin \\
\hline 4 & $18 / 11 / 09$ & 19.55 & 20.27 & $32^{\circ} 43.55^{\prime} \mathrm{S}$ & $32^{\circ} 42.56^{\prime} \mathrm{S}$ & 64534 & 68229 & 375 & Ethanol \\
\hline 4 & $18 / 11 / 09$ & 19.55 & 20.27 & $57^{\circ} 16.05^{\prime} \mathrm{E}$ & $57^{\circ} 15.35^{\prime} \mathrm{E}$ & 58277 & 62663 & 500 & Formalin \\
\hline 4 & $18 / 11 / 09$ & 21.00 & 21.32 & $32^{\circ} 43.30^{\prime} \mathrm{S}$ & $32^{\circ} 43.20^{\prime} \mathrm{S}$ & 68229 & 72171 & 375 & Ethanol \\
\hline 4 & $18 / 11 / 09$ & 21.00 & 21.32 & $57^{\circ} 16.53^{\prime} \mathrm{E}$ & $57^{\circ} 17.87^{\prime} \mathrm{E}$ & 62663 & 68013 & 500 & Formalin \\
\hline 4 & $18 / 11 / 09$ & 21.35 & 22.05 & $\begin{array}{l}32^{\circ} 43.20^{\prime} \mathrm{S} \\
57^{\circ} 18.00^{\prime} \mathrm{E}\end{array}$ & $\begin{array}{l}32^{\circ} 43.51^{\prime} \mathrm{S} \\
57^{\circ} 19.32^{\prime} \mathrm{E}\end{array}$ & 68013 & 74378 & 500 & Formalin \\
\hline 4 & $19 / 11 / 09$ & 14.40 & 15.10 & $32^{\circ} 40.13^{\prime} \mathrm{S}$ & $32^{\circ} 41.40^{\prime} \mathrm{S}$ & 76659 & 80193 & 375 & Ethanol \\
\hline 4 & $19 / 11 / 09$ & 14.40 & 15.10 & $57^{\circ} 19.70^{\prime} \mathrm{E}$ & $57^{\circ} 18.11^{\prime} \mathrm{E}$ & 74379 & 78863 & 500 & Formalin \\
\hline 4 & $19 / 11 / 09$ & 15.15 & 15.50 & $32^{\circ} 41.39^{\prime} \mathrm{S}$ & $32^{\circ} 41.40^{\prime} \mathrm{S}$ & 80193 & 89507 & 375 & Ethanol \\
\hline 4 & $19 / 11 / 09$ & 15.15 & 15.50 & $57^{\circ} 18.12^{\prime} \mathrm{E}$ & $57^{\circ} 18.15^{\prime} \mathrm{E}$ & 78863 & 86932 & 500 & Formalin \\
\hline 4 & $19 / 11 / 09$ & 16.00 & 16.32 & $\begin{array}{l}32^{\circ} 41.46^{\prime} \mathrm{S} \\
57^{\circ} 18.13^{\prime} \mathrm{E}\end{array}$ & $\begin{array}{l}32^{\circ} 41.97^{\prime} \mathrm{S} \\
57^{\circ} 17.24^{\prime} \mathrm{E}\end{array}$ & 86932 & 92643 & 500 & Formalin \\
\hline 5 & $22 / 11 / 09$ & 01.16 & 01.51 & $36^{\circ} 51.10^{\prime} \mathrm{S}$ & $36^{\circ} 47.89^{\prime} \mathrm{S}$ & 89756 & 94331 & 375 & Dried \\
\hline 5 & $22 / 11 / 09$ & 01.16 & 01.51 & $52^{\circ} 14.89^{\prime} \mathrm{E}$ & $52^{\circ} 11.99^{\prime} \mathrm{E}$ & 93085 & 4181 & 500 & Formalin \\
\hline 5 & $22 / 11 / 09$ & 01.55 & 02.32 & $36^{\circ} 47.43^{\prime} \mathrm{S}$ & $36^{\circ} 44.53^{\prime} \mathrm{S}$ & 94331 & 97123 & 375 & Ethanol \\
\hline 5 & $22 / 11 / 09$ & 01.55 & 02.32 & $52^{\circ} 11.40^{\prime} \mathrm{E}$ & $52^{\circ} 05.98^{\prime} \mathrm{E}$ & 4181 & 15624 & 500 & Formalin \\
\hline 5 & $22 / 11 / 09$ & 02.35 & 03.05 & $36^{\circ} 44.88^{\prime} \mathrm{S}$ & $36^{\circ} 48.53^{\prime} \mathrm{S}$ & 97123 & 99376 & 375 & Ethanol \\
\hline 5 & $22 / 11 / 09$ & 02.35 & 03.05 & $52^{\circ} 05.56^{\prime} \mathrm{E}$ & $52^{\circ} 09.30^{\prime} \mathrm{E}$ & 15624 & 21624 & 500 & Formalin \\
\hline 5 & $24 / 11 / 09$ & 21.30 & 22.10 & $36^{\circ} 56.64^{\prime} \mathrm{S}$ & $37^{\circ} 00.72^{\prime} \mathrm{S}$ & 99376 & 2332 & 375 & Dried \\
\hline 5 & $24 / 11 / 09$ & 21.30 & 22.10 & $51^{\circ} 52.27^{\prime} \mathrm{E}$ & $51^{\circ} 46.17^{\prime} \mathrm{E}$ & 21631 & 30210 & 500 & Formalin \\
\hline 5 & $24 / 11 / 09$ & 22.10 & 22.40 & $37^{\circ} 00.72^{\prime} \mathrm{S}$ & $37^{\circ} 03.56^{\prime} \mathrm{S}$ & 2332 & 4676 & 375 & Ethanol \\
\hline 5 & $24 / 11 / 09$ & 22.10 & 22.40 & $51^{\circ} 46.17^{\prime} \mathrm{E}$ & $51^{\circ} 41.32^{\prime} \mathrm{E}$ & 30210 & 36789 & 500 & Formalin \\
\hline 5 & $24 / 11 / 09$ & 22.40 & 23.15 & $37^{\circ} 03.56^{\prime} \mathrm{S}$ & $37^{\circ} 07.04^{\prime} \mathrm{S}$ & 4676 & 6605 & 375 & Ethanol \\
\hline 5 & $24 / 11 / 09$ & 22.40 & 23.15 & $51^{\circ} 41.32^{\prime} \mathrm{E}$ & $51^{\circ} 35.76^{\prime} \mathrm{E}$ & 36789 & 43943 & 500 & Formalin \\
\hline 5 & $25 / 11 / 09$ & 21.05 & 21.35 & $37^{\circ} 57.12^{\prime} \mathrm{S}$ & $37^{\circ} 57.06^{\prime} \mathrm{S}$ & 6605 & 8602 & 375 & Dried \\
\hline 5 & $25 / 11 / 09$ & 21.05 & 21.35 & $50^{\circ} 24.54^{\prime} \mathrm{E}$ & $50^{\circ} 26.01^{\prime} \mathrm{E}$ & 43943 & 51325 & 500 & Formalin \\
\hline 5 & $25 / 11 / 09$ & 21.35 & 22.02 & $37^{\circ} 57.06^{\prime} \mathrm{S}$ & $37^{\circ} 57.12^{\prime} \mathrm{S}$ & 8602 & 10812 & 375 & Ethanol \\
\hline 5 & $25 / 11 / 09$ & 21.35 & 22.02 & $50^{\circ} 26.01^{\prime} \mathrm{E}$ & $50^{\circ} 26.89^{\prime} \mathrm{E}$ & 51325 & 56864 & 500 & Formalin \\
\hline 5 & $25 / 11 / 09$ & 22.02 & 22.32 & $37^{\circ} 57.12^{\prime} \mathrm{S}$ & $37^{\circ} 57.22^{\prime} \mathrm{S}$ & 10812 & 12980 & 375 & Ethanol \\
\hline 5 & $25 / 11 / 09$ & 22.02 & 22.32 & $50^{\circ} 26.89^{\prime} \mathrm{E}$ & $50^{\circ} 24.94^{\prime} \mathrm{E}$ & 56864 & 76619 & 500 & Formalin \\
\hline 6 & $27 / 11 / 09$ & 13.51 & 14.23 & $37^{\circ} 57.71^{\prime} \mathrm{S}$ & $37^{\circ} 57.56^{\prime} \mathrm{S}$ & 12980 & 15968 & 375 & Ethanol \\
\hline 6 & $27 / 11 / 09$ & 13.51 & 14.23 & $50^{\circ} 25.81^{\prime} \mathrm{E}$ & $50^{\circ} 25.69^{\prime} \mathrm{E}$ & 61994 & 70072 & 500 & Formalin \\
\hline 6 & $27 / 11 / 09$ & 14.23 & 14.58 & $37^{\circ} 57.56^{\prime} \mathrm{S}$ & $37^{\circ} 57.53^{\prime} \mathrm{S}$ & 15968 & 19170 & 375 & Dried \\
\hline 6 & $27 / 11 / 09$ & 14.23 & 14.58 & $50^{\circ} 25.69^{\prime} \mathrm{E}$ & $50^{\circ} 24.28^{\prime} \mathrm{E}$ & 70072 & 79781 & 500 & Formalin \\
\hline 6 & $27 / 11 / 09$ & 18.10 & 18.45 & $37^{\circ} 57.08^{\prime} \mathrm{S}$ & $37^{\circ} 58.10^{\prime} \mathrm{S}$ & 19170 & 21681 & 375 & Ethanol \\
\hline 6 & $27 / 11 / 09$ & 18.10 & 18.45 & $50^{\circ} 23.96^{\prime} \mathrm{E}$ & $50^{\circ} 25.18^{\prime} \mathrm{E}$ & 79781 & 85554 & 500 & Formalin \\
\hline 7 & $29 / 11 / 09$ & 18.10 & 18.47 & $41^{\circ} 31.09^{\prime} \mathrm{S}$ & $41^{\circ} 30.66^{\prime} \mathrm{S}$ & 21681 & 24603 & 375 & Ethanol \\
\hline 7 & $29 / 11 / 09$ & 18.10 & 18.47 & $49^{\circ} 26.99^{\prime} \mathrm{E}$ & $49^{\circ} 28.44^{\prime} \mathrm{E}$ & 85554 & 94101 & 500 & Formalin \\
\hline 7 & $29 / 11 / 09$ & 19.55 & 20.25 & $41^{\circ} 29.92^{\prime} \mathrm{S}$ & $41^{\circ} 27.55^{\prime} \mathrm{S}$ & 28559 & 32205 & 375 & Ethanol \\
\hline 7 & $29 / 11 / 09$ & 19.55 & 20.25 & $49^{\circ} 231.27^{\prime} \mathrm{E}$ & $49^{\circ} 33.59^{\prime} \mathrm{E}$ & 3533 & 11434 & 500 & Formalin \\
\hline 7 & $29 / 11 / 09$ & 20.30 & 21.02 & $41^{\circ} 27.64^{\prime} \mathrm{S}$ & $41^{\circ} 29.04^{\prime} \mathrm{S}$ & 32205 & 36270 & 375 & Ethanol \\
\hline 7 & $29 / 11 / 09$ & 20.30 & 21.02 & 49³3.39'E & $49^{\circ} 31.78^{\prime} \mathrm{E}$ & 11434 & 20321 & 500 & Formalin \\
\hline 7 & $30 / 11 / 09$ & 17.55 & 18.25 & $41^{\circ} 34.73^{\prime} \mathrm{S}$ & $41^{\circ} 34.59^{\prime} \mathrm{S}$ & 38289 & 41038 & 375 & Ethanol \\
\hline 7 & $30 / 11 / 09$ & 17.55 & 18.25 & $48^{\circ} 54.16^{\prime} \mathrm{E}$ & $48^{\circ} 48.37^{\prime} \mathrm{E}$ & 26670 & 32467 & 500 & Formalin \\
\hline 8 & $02 / 12 / 09$ & 13.25 & 13.55 & $41^{\circ} 24.77^{\prime} \mathrm{S}$ & $41^{\circ} 24.39^{\prime} \mathrm{S}$ & 41030 & 44887 & 375 & Ethanol \\
\hline 8 & $02 / 12 / 09$ & 13.25 & 13.55 & $42^{\circ} 57.46^{\prime} \mathrm{E}$ & $42^{\circ} 57.64^{\prime} \mathrm{E}$ & 32480 & 39906 & 500 & Formalin \\
\hline 8 & $02 / 12 / 09$ & 13.59 & 14.22 & $41_{\mathrm{o}} 24.47^{\prime} \mathrm{S}$ & $41^{\circ} 24.79^{\prime} \mathrm{S}$ & 44887 & 47272 & 375 & Ethanol \\
\hline 8 & $02 / 12 / 09$ & 13.59 & 14.22 & $42^{\circ} 57.34^{\prime} \mathrm{E}$ & $42^{\circ} 56.00^{\prime} \mathrm{E}$ & 39906 & 45372 & 500 & Formalin \\
\hline
\end{tabular}




\begin{tabular}{|c|c|c|c|c|c|c|c|c|c|}
\hline 8 & $02 / 12 / 09$ & 14.23 & 14.58 & \multirow{2}{*}{$\begin{array}{l}41^{\circ} 24.80^{\prime} \mathrm{S} \\
42^{\circ} 55.95{ }^{\prime} \mathrm{E} \\
\end{array}$} & \multirow{2}{*}{$\begin{array}{l}41^{\circ} 25.11^{\prime} \mathrm{S} \\
42^{\circ} 54.46^{\prime} \mathrm{E}\end{array}$} & \multirow{2}{*}{\begin{tabular}{|l|}
47272 \\
45372 \\
\end{tabular}} & \multirow{2}{*}{\begin{tabular}{|l|}
50845 \\
51749
\end{tabular}} & \multirow{2}{*}{\begin{tabular}{|l|}
375 \\
500
\end{tabular}} & \multirow{2}{*}{$\begin{array}{l}\text { Dried } \\
\text { Formalin }\end{array}$} \\
\hline 8 & $02 / 12 / 09$ & 14.23 & 14.58 & & & & & & \\
\hline 8 & $02 / 12 / 09$ & 19.50 & 20.21 & \multirow{2}{*}{$\begin{array}{l}41^{\circ} 25.83^{\prime} \mathrm{S} \\
42^{\circ} 54.61^{\prime} \mathrm{E}\end{array}$} & \multirow{2}{*}{$\begin{array}{l}41^{\circ} 26.12^{\prime} \mathrm{S} \\
42^{\circ} 52.93^{\prime} \mathrm{E}\end{array}$} & 50845 & 54545 & 375 & Ethanol \\
\hline 8 & $02 / 12 / 09$ & 19.50 & 20.21 & & & 51749 & 59814 & 500 & Formalin \\
\hline 8 & $02 / 12 / 09$ & 20.30 & 20.55 & \multirow{2}{*}{$\begin{array}{l}41^{\circ} 26.23^{\prime} \mathrm{S} \\
42^{\circ} 52.66^{\prime} \mathrm{E}\end{array}$} & \multirow{2}{*}{$\begin{array}{l}41^{\circ} 26.75^{\prime} \mathrm{S} \\
42^{\circ} 52.37^{\prime} \mathrm{E}\end{array}$} & 54545 & 58277 & 375 & Ethanol \\
\hline 8 & $02 / 12 / 09$ & 20.30 & 20.55 & & & 59814 & 68056 & 500 & Formalin \\
\hline 8 & $02 / 12 / 09$ & 21.03 & 21.40 & \multirow{2}{*}{$\begin{array}{l}41^{\circ} 26.36^{\prime} \mathrm{S} \\
42^{\circ} 52.17^{\prime} \mathrm{E}\end{array}$} & \multirow{2}{*}{$\begin{array}{l}41^{\circ} 25.04^{\prime} \mathrm{S} \\
42^{\circ} 54.57^{\prime} \mathrm{E}\end{array}$} & 58277 & 62808 & 375 & Dried \\
\hline 8 & $02 / 12 / 09$ & 21.03 & 21.40 & & & 68057 & 77744 & 500 & Formalin \\
\hline 9 & $08 / 12 / 09$ & 08.15 & 08.45 & \multirow{2}{*}{$\begin{array}{l}38^{\circ} 30.58^{\prime} \mathrm{S} \\
46^{\circ} 44.16^{\prime} \mathrm{E}\end{array}$} & \multirow{2}{*}{$\begin{array}{l}38^{\circ} 30.90^{\prime} \mathrm{S} \\
46^{\circ} 42.75^{\prime} \mathrm{E}\end{array}$} & 62589 & 67488 & 375 & Ethanol \\
\hline 9 & $08 / 12 / 09$ & 08.15 & 08.45 & & & 77815 & 86942 & 500 & Formalin \\
\hline 9 & $08 / 12 / 09$ & 08.50 & 09.36 & \multirow{2}{*}{$\begin{array}{l}38^{\circ} 30.92^{\prime} \mathrm{S} \\
46^{\circ} 42.62^{\prime} \mathrm{E}\end{array}$} & \multirow{2}{*}{$\begin{array}{l}38^{\circ} 29.75^{\prime} \mathrm{S} \\
46^{\circ} 43.63^{\prime} \mathrm{E} \\
\end{array}$} & 67488 & 71620 & 375 & Ethanol \\
\hline 9 & $08 / 12 / 09$ & 08.50 & 09.36 & & & 86942 & 97309 & 500 & Formalin \\
\hline 9 & $08 / 12 / 09$ & 19.50 & 20.25 & \multirow{2}{*}{$\begin{array}{l}38^{\circ} 28.41^{\prime} \mathrm{S} \\
46^{\circ} 48.32^{\prime} \mathrm{E}\end{array}$} & \multirow{2}{*}{$\begin{array}{l}38^{\circ} 28.48^{\prime} \mathrm{S} \\
46^{\circ} 47.60^{\prime} \mathrm{E}\end{array}$} & 75355 & 79195 & 375 & Ethanol \\
\hline 9 & $08 / 12 / 09$ & 19.50 & 20.25 & & & 5050 & 15138 & 500 & Formalin \\
\hline 9 & $08 / 12 / 09$ & 20.30 & 21.05 & \multirow{2}{*}{$\begin{array}{l}38^{\circ} 28.52^{\prime} \mathrm{S} \\
46^{\circ} 47.61^{\prime} \mathrm{E}\end{array}$} & \multirow{2}{*}{$\begin{array}{l}38^{\circ} 28.36^{\prime} \mathrm{S} \\
46^{\circ} 46.96^{\prime} \mathrm{E}\end{array}$} & 79195 & 82645 & 375 & Ethanol \\
\hline 9 & $08 / 12 / 09$ & 20.30 & 21.05 & & & 15138 & 2573 & 500 & Formalin \\
\hline 10 & $12 / 12 / 09$ & 20.42 & 21.25 & \multirow{2}{*}{$\begin{array}{l}31^{\circ} 41.34^{\prime} \mathrm{S} \\
42^{\circ} 51.81^{\prime} \mathrm{E}\end{array}$} & \multirow{2}{*}{$\begin{array}{l}31^{\circ} 41.22^{\prime} \mathrm{S} \\
42^{\circ} 48.41^{\prime} \mathrm{E}\end{array}$} & 90844 & 95956 & 375 & Ethanol \\
\hline 10 & $12 / 12 / 09$ & 20.42 & 21.25 & & & 44838 & 55394 & 500 & Formalin \\
\hline 10 & $12 / 12 / 09$ & 21.27 & 21.56 & \multirow{2}{*}{$\begin{array}{l}31^{\circ} 41.16^{\prime} \mathrm{S} \\
42^{\circ} 48.49^{\prime} \mathrm{E}\end{array}$} & \multirow{2}{*}{$\begin{array}{l}31^{\circ} 40.05^{\prime} \mathrm{S} \\
42^{\circ} 49.35^{\prime} \mathrm{E}\end{array}$} & 95956 & 99326 & 375 & Ethanol \\
\hline 10 & $12 / 12 / 09$ & 21.27 & 21.56 & & & 55394 & 63385 & 500 & Formalin \\
\hline 10 & $13 / 12 / 09$ & 13.20 & 14.10 & \multirow{2}{*}{$\begin{array}{l}31^{\circ} 37.37^{\prime} \mathrm{S} \\
42^{\circ} 49.18^{\prime} \mathrm{E}\end{array}$} & \multirow{2}{*}{$\begin{array}{l}31^{\circ} 37.37^{\prime} \mathrm{S} \\
42^{\circ} 49.18^{\prime} \mathrm{E}\end{array}$} & 99394 & 3968 & 375 & Ethanol \\
\hline 10 & $13 / 12 / 09$ & 13.20 & 14.10 & & & 63385 & 74341 & 500 & Formalin \\
\hline 10 & $13 / 12 / 09$ & 14.12 & 14.57 & \multirow{2}{*}{$\begin{array}{l}31^{\circ} 37.36^{\prime} \mathrm{S} \\
42^{\circ} 49.19^{\prime} \mathrm{E}\end{array}$} & \multirow{2}{*}{$\begin{array}{l}31^{\circ} 37.37^{\prime} \mathrm{S} \\
42^{\circ} 49.19^{\prime} \mathrm{E}\end{array}$} & 3968 & 8254 & 375 & Ethanol \\
\hline 10 & $13 / 12 / 09$ & 14.12 & 14.57 & & & 74341 & 84309 & 500 & Formalin \\
\hline
\end{tabular}


Table 5 Multinet deployments

\begin{tabular}{|c|c|c|c|c|c|c|c|c|c|}
\hline Station & Date & Net & $\begin{array}{l}\text { Time } \\
\text { Start / } \\
\text { Stop }\end{array}$ & $\begin{array}{l}\text { Start } \\
\text { Position } \\
\text { (Vessel) }\end{array}$ & $\begin{array}{l}\text { End } \\
\text { position } \\
\text { (Vessel) }\end{array}$ & $\begin{array}{l}\begin{array}{l}\text { Pressure } \\
\text { (dbar) }\end{array} \\
\text { Start / } \\
\text { Stop }\end{array}$ & $\begin{array}{l}\text { Volume } \\
\left(\mathrm{m}^{3}\right)\end{array}$ & $\begin{array}{l}\text { Flow in/ } \\
\text { Flow out } \\
\text { Start/ } \\
\text { Stop }\end{array}$ & $\begin{array}{l}\text { Flow } \\
\text { Ratio } \\
(\%)\end{array}$ \\
\hline 2 (PL3) & $14 / 11 / 09$ & 1 & $\begin{array}{l}11.27 .50 \\
11.30 .20\end{array}$ & $\begin{array}{l}26^{\circ} 56.37^{\prime} \mathrm{S} \\
56^{\circ} 14.06^{\prime} \mathrm{E}\end{array}$ & $\begin{array}{l}26^{\circ} 56.31^{\prime} \mathrm{S} \\
56^{\circ} 13.99^{\prime} \mathrm{E}\end{array}$ & $\begin{array}{l}250.1 \\
202.9\end{array}$ & 8 & $\begin{array}{l}0.3 / 0.3 \\
0.2 / 0.2\end{array}$ & $\begin{array}{l}100.0 \\
100.0\end{array}$ \\
\hline 2 (PL3) & $14 / 11 / 09$ & 2 & $\begin{array}{l}11.30 .21 \\
11.34 .47\end{array}$ & $\begin{array}{l}26^{\circ} 56.31^{\prime} \mathrm{S} \\
56^{\circ} 13.99^{\prime} \mathrm{E}\end{array}$ & $\begin{array}{l}26^{\circ} 56.24^{\prime} \mathrm{S} \\
56^{\circ} 13.88^{\prime} \mathrm{E}\end{array}$ & $\begin{array}{l}202.6 \\
151.8\end{array}$ & 54 & $\begin{array}{l}0.1 / 0.3 \\
0.7 / 0.3 \\
\end{array}$ & $\begin{array}{l}33.3 \\
233.3\end{array}$ \\
\hline 2 (PL3) & $14 / 11 / 09$ & 3 & $\begin{array}{l}11.34 .48 \\
11.42 .51 \\
\end{array}$ & $\begin{array}{l}26^{\circ} 56.24^{\prime} \mathrm{S} \\
56^{\circ} 13.88^{\prime} \mathrm{E}\end{array}$ & $\begin{array}{l}26^{\circ} 56.19^{\prime} \mathrm{S} \\
56^{\circ} 13.77^{\prime} \mathrm{E}\end{array}$ & $\begin{array}{l}151.6 \\
101.6 \\
\end{array}$ & 224 & $\begin{array}{l}0.8 / 0.2 \\
2.1 / 1.8 \\
\end{array}$ & $\begin{array}{l}400 \\
116.7 \\
\end{array}$ \\
\hline 2 (PL3) & $14 / 11 / 09$ & 4 & $\begin{array}{l}11.42 .52 \\
11.46 .26\end{array}$ & $\begin{array}{l}26^{\circ} 56.19^{\prime} \mathrm{S} \\
56^{\circ} 13.77^{\prime} \mathrm{E}\end{array}$ & $\begin{array}{l}26^{\circ} 56.17^{\prime} \mathrm{S} \\
56^{\circ} 13.75^{\prime} \mathrm{E}\end{array}$ & $\begin{array}{l}101.3 \\
50.6\end{array}$ & 101 & $\begin{array}{l}2.1 / 1.9 \\
1.8 / 1.7\end{array}$ & $\begin{array}{l}110.5 \\
105.9\end{array}$ \\
\hline 2 (PL3) & $14 / 11 / 09$ & 5 & $\begin{array}{l}11.46 .27 \\
11.49 .23 \\
\end{array}$ & $\begin{array}{l}26^{\circ} 56.17^{\prime} \mathrm{S} \\
56^{\circ} 13.75^{\prime} \mathrm{E} \\
\end{array}$ & $\begin{array}{l}26^{\circ} 56.20^{\prime} \mathrm{S} \\
56^{\circ} 13.81^{\prime} \mathrm{E} \\
\end{array}$ & $\begin{array}{l}50.3 \\
1.5 \\
\end{array}$ & 69 & $\begin{array}{l}2.0 / 1.8 \\
1.6 / 0.9 \\
\end{array}$ & $\begin{array}{l}111.1 \\
177.8 \\
\end{array}$ \\
\hline 2 (PL4) & $14 / 11 / 09$ & 1 & $\begin{array}{l}12.18 .58 \\
12.21 .49 \\
\end{array}$ & $\begin{array}{l}26^{\circ} 56.46^{\prime} \mathrm{S} \\
56^{\circ} 14.72^{\prime} \mathrm{E}\end{array}$ & $\begin{array}{l}26^{\circ} 56.49^{\prime} \mathrm{S} \\
56^{\circ} 14.82^{\prime} \mathrm{E}\end{array}$ & $\begin{array}{l}199.3 \\
151.3 \\
\end{array}$ & 15 & $\begin{array}{l}0.2 / 0.2 \\
0.1 / 0.3\end{array}$ & $\begin{array}{l}100.0 \\
33.3\end{array}$ \\
\hline 2 (PL4) & $14 / 11 / 09$ & 2 & $\begin{array}{l}12.21 .50 \\
12.27 .55\end{array}$ & $\begin{array}{l}26^{\circ} 56.49^{\prime} \mathrm{S} \\
56^{\circ} 14.82^{\prime} \mathrm{E}\end{array}$ & $\begin{array}{l}26^{\circ} 56.54^{\prime} \mathrm{S} \\
56^{\circ} 15.03^{\prime} \mathrm{E}\end{array}$ & $\begin{array}{l}151.3 \\
101.8\end{array}$ & 123 & $\begin{array}{l}0.1 / 0.1 \\
1.0 / 1.1\end{array}$ & $\begin{array}{l}100.0 \\
90.9\end{array}$ \\
\hline 2 (PL4) & $14 / 11 / 09$ & 3 & $\begin{array}{l}12.27 .56 \\
12.33 .30 \\
\end{array}$ & $\begin{array}{l}26^{\circ} 56.54^{\prime} \mathrm{S} \\
56^{\circ} 15.03^{\prime} \mathrm{E}\end{array}$ & $\begin{array}{l}26^{\circ} 56.58^{\prime} \mathrm{S} \\
56^{\circ} 15.20^{\prime} \mathrm{E}\end{array}$ & $\begin{array}{l}101.9 \\
50.7 \\
\end{array}$ & 151 & $\begin{array}{l}1.1 / 0.8 \\
1.5 / 1.7 \\
\end{array}$ & $\begin{array}{l}137.5 \\
88.2 \\
\end{array}$ \\
\hline 2 (PL4) & $14 / 11 / 09$ & 4 & $\begin{array}{l}12.33 .31 \\
12.35 .24 \\
\end{array}$ & $\begin{array}{l}26^{\circ} 56.58^{\prime} \mathrm{S} \\
56^{\circ} 15.20^{\prime} \mathrm{E}\end{array}$ & $\begin{array}{l}26^{\circ} 56.60^{\prime} \mathrm{S} \\
56^{\circ} 15.27^{\prime} \mathrm{E}\end{array}$ & $\begin{array}{l}51.0 \\
25.6 \\
\end{array}$ & 50 & $\begin{array}{l}1.2 / 1.4 \\
1.7 / 1.6 \\
\end{array}$ & $\begin{array}{l}85.7 \\
106.2 \\
\end{array}$ \\
\hline 2 (PL4) & $14 / 11 / 09$ & 5 & $\begin{array}{l}12.35 .25 \\
12.37 .03 \\
\end{array}$ & $\begin{array}{l}26^{\circ} 56.60^{\prime} \mathrm{S} \\
56^{\circ} 15.27^{\prime} \mathrm{E}\end{array}$ & $\begin{array}{l}26^{\circ} 56.61 ' \mathrm{~S} \\
56^{\circ} 15.34^{\prime} \mathrm{E}\end{array}$ & $\begin{array}{l}25.6 \\
0.6 \\
\end{array}$ & 42 & $\begin{array}{l}1.5 / 1.5 \\
1.4 / 0.8 \\
\end{array}$ & $\begin{array}{l}100 \\
175 \\
\end{array}$ \\
\hline 2 (PL7) & $14 / 11 / 09$ & 1 & $\begin{array}{l}19.39 .13 \\
19.48 .31\end{array}$ & $\begin{array}{l}26^{\circ} 57.27^{\prime} \mathrm{S} \\
56^{\circ} 19.24^{\prime} \mathrm{E}\end{array}$ & $\begin{array}{l}26^{\circ} 57.57^{\prime} \mathrm{S} \\
56^{\circ} 19.61^{\prime} \mathrm{E}\end{array}$ & $\begin{array}{l}252.0 \\
202.8\end{array}$ & 61 & $\begin{array}{l}0.2 / 0.3 \\
0.8 / 0.1\end{array}$ & $\begin{array}{l}66.7 \\
800.0\end{array}$ \\
\hline 2 (PL7) & $14 / 11 / 09$ & 2 & $\begin{array}{l}19.48 .32 \\
19.53 .20 \\
\end{array}$ & $\begin{array}{l}26^{\circ} 57.57^{\prime} \mathrm{S} \\
56^{\circ} 19.61^{\prime} \mathrm{E}\end{array}$ & $\begin{array}{l}26^{\circ} 57.66^{\prime} \mathrm{S} \\
56^{\circ} 19.50^{\prime} \mathrm{E} \\
\end{array}$ & $\begin{array}{l}202.1 \\
147.8 \\
\end{array}$ & 90 & $\begin{array}{l}0.7 / 0.3 \\
1.1 / 1.3 \\
\end{array}$ & $\begin{array}{l}233.3 \\
84.6 \\
\end{array}$ \\
\hline 2 (PL7) & $14 / 11 / 09$ & 3 & $\begin{array}{l}19.53 .21 \\
19.56 .03\end{array}$ & $\begin{array}{l}26^{\circ} 57.66^{\prime} \mathrm{S} \\
56^{\circ} 19.50^{\prime} \mathrm{E}\end{array}$ & $\begin{array}{l}26^{\circ} 57.69^{\prime} \mathrm{S} \\
56^{\circ} 19.46^{\prime} \mathrm{E}\end{array}$ & $\begin{array}{l}147.1 \\
100.2\end{array}$ & 65 & $\begin{array}{l}1.1 / 1.3 \\
1.6 / 1.6\end{array}$ & $\begin{array}{l}84.6 \\
100.0\end{array}$ \\
\hline 2 (PL7) & $14 / 11 / 09$ & 4 & $\begin{array}{l}19.56 .04 \\
19.59 .55\end{array}$ & $\begin{array}{l}26^{\circ} 57.69^{\prime} \mathrm{S} \\
56^{\circ} 19.46^{\prime} \mathrm{E}\end{array}$ & $\begin{array}{l}26^{\circ} 57.70^{\prime} \mathrm{S} \\
56^{\circ} 19.42^{\prime} \mathrm{E}\end{array}$ & $\begin{array}{l}100.2 \\
50.6\end{array}$ & 98 & $\begin{array}{l}1.4 / 1.4 \\
1.8 / 1.7\end{array}$ & $\begin{array}{l}100.0 \\
105.9\end{array}$ \\
\hline 2 (PL7) & $14 / 11 / 09$ & 5 & $\begin{array}{l}19.59 .56 \\
20.03 .14\end{array}$ & $\begin{array}{l}26^{\circ} 57.70^{\prime} \mathrm{S} \\
56^{\circ} 19.42^{\prime} \mathrm{E}\end{array}$ & $\begin{array}{l}26^{\circ} 57.69^{\prime} \mathrm{S} \\
56^{\circ} 19.39^{\prime} \mathrm{E}\end{array}$ & $\begin{array}{l}50.6 \\
1.9\end{array}$ & 75 & $\begin{array}{l}1.6 / 1.6 \\
1.0 / 1.7\end{array}$ & $\begin{array}{l}100.0 \\
142.9\end{array}$ \\
\hline 2 (PL8) & $14 / 11 / 09$ & 1 & $\begin{array}{l}20.26 .11 \\
20.29 .04 \\
\end{array}$ & $\begin{array}{l}26^{\circ} 57.35^{\prime} \mathrm{S} \\
56^{\circ} 18.88^{\prime} \mathrm{E}\end{array}$ & $\begin{array}{l}26^{\circ} 57.25^{\prime} \mathrm{S} \\
56^{\circ} 18.71^{\prime} \mathrm{E} \\
\end{array}$ & $\begin{array}{l}201.2 \\
151.9 \\
\end{array}$ & 10 & $\begin{array}{l}0.2 / 0.3 \\
0.8 / 0.1 \\
\end{array}$ & $\begin{array}{l}66.7 \\
800.0 \\
\end{array}$ \\
\hline 2 (PL8) & $14 / 11 / 09$ & 2 & $\begin{array}{l}20.29 .05 \\
20.34 .14\end{array}$ & $\begin{array}{l}26^{\circ} 57.25^{\prime} \mathrm{S} \\
56^{\circ} 18.71^{\prime} \mathrm{E}\end{array}$ & $\begin{array}{l}26^{\circ} 57.07^{\prime} \mathrm{S} \\
56^{\circ} 18.43^{\prime} \mathrm{E}\end{array}$ & $\begin{array}{l}151.9 \\
101.4\end{array}$ & 66 & $\begin{array}{l}0.8 / 0.2 \\
1.2 / 0.1\end{array}$ & $\begin{array}{l}400.0 \\
1200.0\end{array}$ \\
\hline 2 (PL8) & $14 / 11 / 09$ & 3 & $\begin{array}{l}20.34 .15 \\
20.40 .30 \\
\end{array}$ & $\begin{array}{l}26^{\circ} 57.07^{\prime} \mathrm{S} \\
56^{\circ} 18.43^{\prime} \mathrm{E}\end{array}$ & $\begin{array}{l}26^{\circ} 56.86^{\prime} \mathrm{S} \\
56^{\circ} 18.09^{\prime} \mathrm{E} \\
\end{array}$ & $\begin{array}{l}101.4 \\
51.4 \\
\end{array}$ & 155 & $\begin{array}{l}1.3 / 0.2 \\
1.2 / 1.3 \\
\end{array}$ & $\begin{array}{l}650.0 \\
92.3 \\
\end{array}$ \\
\hline 2 (PL8) & $14 / 11 / 09$ & 4 & $\begin{array}{l}20.40 .31 \\
20.42 .18 \\
\end{array}$ & $\begin{array}{l}26^{\circ} 56.86^{\prime} \mathrm{S} \\
56^{\circ} 18.09^{\prime} \mathrm{E}\end{array}$ & $\begin{array}{l}26^{\circ} 56.80^{\prime} \mathrm{S} \\
56^{\circ} 17.99^{\prime} \mathrm{E}\end{array}$ & $\begin{array}{l}51.3 \\
25.2\end{array}$ & 41 & $\begin{array}{l}1.2 / 1.2 \\
1.8 / 1.6\end{array}$ & $\begin{array}{l}100.0 \\
112.5\end{array}$ \\
\hline 2 (PL8) & $14 / 11 / 09$ & 5 & $\begin{array}{l}20.42 .19 \\
20.43 .37\end{array}$ & $\begin{array}{l}26^{\circ} 56.80^{\prime} \mathrm{S} \\
56^{\circ} 17.99^{\prime} \mathrm{E}\end{array}$ & $\begin{array}{l}26^{\circ} 56.74^{\prime} \mathrm{S} \\
56^{\circ} 17.91^{\prime} \mathrm{E}\end{array}$ & $\begin{array}{l}24.6 \\
0.6\end{array}$ & 27 & $\begin{array}{l}1.8 / 1.6 \\
1.2 / 1.3\end{array}$ & $\begin{array}{l}112.5 \\
92.3\end{array}$ \\
\hline 4 (PL18) & $17 / 11 / 09$ & 1 & $\begin{array}{l}08.30 .15 \\
08.33 .07 \\
\end{array}$ & $\begin{array}{l}32^{\circ} 42.86^{\prime} \mathrm{S} \\
57^{\circ} 17.82^{\prime} \mathrm{E}\end{array}$ & $\begin{array}{l}32^{\circ} 42.86^{\prime} \mathrm{S} \\
57^{\circ} 17.80^{\prime} \mathrm{E}\end{array}$ & $\begin{array}{l}199.9 \\
155.9 \\
\end{array}$ & 33 & $\begin{array}{l}0.5 / 0.2 \\
1.1 / 0.3\end{array}$ & $\begin{array}{l}250.0 \\
366.7\end{array}$ \\
\hline 4 (PL18) & $17 / 11 / 09$ & 2 & $\begin{array}{l}08.33 .08 \\
08.38 .32 \\
\end{array}$ & $\begin{array}{l}32^{\circ} 42.86^{\prime} \mathrm{S} \\
57^{\circ} 17.80^{\prime} \mathrm{E}\end{array}$ & $\begin{array}{l}32^{\circ} 42.86 \text { 'S } \\
57^{\circ} 17.76 \text { 'E }\end{array}$ & $\begin{array}{l}155.2 \\
101.1 \\
\end{array}$ & 121 & $\begin{array}{l}1.0 / 0.2 \\
1.2 / 1.4 \\
\end{array}$ & $\begin{array}{l}500.0 \\
85.7 \\
\end{array}$ \\
\hline 4 (PL18) & $17 / 11 / 09$ & 3 & $\begin{array}{l}08.38 .33 \\
08.43 .46 \\
\end{array}$ & $\begin{array}{l}32^{\circ} 42.86^{\prime} \mathrm{S} \\
57^{\circ} 17.76^{\prime} \mathrm{E}\end{array}$ & $\begin{array}{l}32^{\circ} 42.88^{\prime} \mathrm{S} \\
57^{\circ} 17.71^{\prime} \mathrm{E}\end{array}$ & $\begin{array}{l}101.3 \\
51.9 \\
\end{array}$ & 121 & $\begin{array}{l}1.0 / 1.2 \\
1.2 / 1.3 \\
\end{array}$ & \begin{tabular}{|l|}
83.3 \\
92.3 \\
\end{tabular} \\
\hline 4 (PL18) & $17 / 11 / 09$ & 4 & $\begin{array}{l}08.43 .47 \\
08.45 .55\end{array}$ & $\begin{array}{l}32^{\circ} 42.88^{\prime} \mathrm{S} \\
57^{\circ} 17.71^{\prime} \mathrm{E}\end{array}$ & $\begin{array}{l}32^{\circ} 42.88^{\prime} \mathrm{S} \\
57^{\circ} 17.70^{\prime} \mathrm{E}\end{array}$ & $\begin{array}{l}52.2 \\
25.8\end{array}$ & 44 & $\begin{array}{l}1.0 / 1.1 \\
1.2 / 1.3\end{array}$ & $\begin{array}{l}90.9 \\
92.3\end{array}$ \\
\hline 4 (PL18) & $17 / 11 / 09$ & 5 & $\begin{array}{l}08.45 .56 \\
08.47 .49 \\
\end{array}$ & $\begin{array}{l}32^{\circ} 42.88^{\prime} \mathrm{S} \\
57^{\circ} 17.70^{\prime} \mathrm{E}\end{array}$ & $\begin{array}{l}32^{\circ} 42.87^{\prime} \mathrm{S} \\
57^{\circ} 17.71^{\prime} \mathrm{E}\end{array}$ & $\begin{array}{l}26.1 \\
1.3 \\
\end{array}$ & 50 & $\begin{array}{l}0.8 / 1.0 \\
1.4 / 1.4 \\
\end{array}$ & $\begin{array}{l}80.0 \\
100.0 \\
\end{array}$ \\
\hline 4 (PL26) & $18 / 11 / 09$ & 1 & $\begin{array}{l}17.17 .51 \\
17.22 .08\end{array}$ & $\begin{array}{l}32^{\circ} 44.07^{\prime} \mathrm{S} \\
57^{\circ} 17.06^{\prime} \mathrm{E}\end{array}$ & $\begin{array}{l}32^{\circ} 44.16^{\prime} \mathrm{S} \\
57^{\circ} 16.97^{\prime} \mathrm{E}\end{array}$ & $\begin{array}{l}201.2 \\
151.1\end{array}$ & 78 & $\begin{array}{l}0.5 / 0.7 \\
1.2 / 1.1\end{array}$ & $\begin{array}{l}71.4 \\
109.1\end{array}$ \\
\hline 4 (PL26) & $18 / 11 / 09$ & 2 & $\begin{array}{l}17.22 .09 \\
17.27 .35\end{array}$ & $\begin{array}{l}32^{\circ} 44.16^{\prime} \mathrm{S} \\
57^{\circ} 16.97^{\prime} \mathrm{E}\end{array}$ & $\begin{array}{l}32^{\circ} 44.30^{\prime} \mathrm{S} \\
57^{\circ} 16.83^{\prime} \mathrm{E}\end{array}$ & $\begin{array}{l}151.1 \\
100.3 \\
\end{array}$ & 112 & $\begin{array}{l}1.4 / 1.1 \\
1.2 / 1.0 \\
\end{array}$ & $\begin{array}{l}127.3 \\
120.0 \\
\end{array}$ \\
\hline 4 (PL26) & $18 / 11 / 09$ & 3 & $\begin{array}{l}17.27 .36 \\
17.33 .04\end{array}$ & $\begin{array}{l}32^{\circ} 44.30^{\prime} \mathrm{S} \\
57^{\circ} 16.83^{\prime} \mathrm{E}\end{array}$ & $\begin{array}{l}32^{\circ} 44.42^{\prime} \mathrm{S} \\
57^{\circ} 16.70^{\prime} \mathrm{E}\end{array}$ & $\begin{array}{l}100.2 \\
51.2\end{array}$ & 108 & $\begin{array}{l}1.4 / 0.9 \\
0.2 / 0.5\end{array}$ & $\begin{array}{l}155.6 \\
40.0\end{array}$ \\
\hline 4 (PL26) & $18 / 11 / 09$ & 4 & $\begin{array}{l}17.33 .05 \\
17.35 .21\end{array}$ & $\begin{array}{l}32^{\circ} 44.42^{\prime} \mathrm{S} \\
57^{\circ} 16.70^{\prime} \mathrm{E}\end{array}$ & $\begin{array}{l}32^{\circ} 44.46^{\prime} \mathrm{S} \\
57^{\circ} 16.65^{\prime} \mathrm{E}\end{array}$ & $\begin{array}{l}51.3 \\
24.9\end{array}$ & 32 & $\begin{array}{l}0.7 / 0.7 \\
0.8 / 0.8\end{array}$ & $\begin{array}{l}100.0 \\
100.0\end{array}$ \\
\hline
\end{tabular}




\begin{tabular}{|c|c|c|c|c|c|c|c|c|c|}
\hline 4 (PL26) & $18 / 11 / 09$ & 5 & $\begin{array}{l}17.35 .22 \\
17.37 .56 \\
\end{array}$ & $\begin{array}{l}32^{\circ} 44.46^{\prime} \mathrm{S} \\
57^{\circ} 16.65^{\prime} \mathrm{E}\end{array}$ & $\begin{array}{l}32^{\circ} 44.54^{\prime} \mathrm{S} \\
57^{\circ} 16.57^{\prime} \mathrm{E}\end{array}$ & $\begin{array}{l}24.6 \\
1.0 \\
\end{array}$ & 45 & $\begin{array}{l}1.2 / 0.9 \\
0.5 / 0.8 \\
\end{array}$ & $\begin{array}{l}133.3 \\
62.5 \\
\end{array}$ \\
\hline 4 (PL27) & $18 / 11 / 09$ & 1 & $\begin{array}{l}21.40 .16 \\
21.44 .34\end{array}$ & $\begin{array}{l}32^{\circ} 43.22^{\prime} \mathrm{S} \\
57^{\circ} 18.21^{\prime} \mathrm{E}\end{array}$ & $\begin{array}{l}32^{\circ} 43.28^{\prime} \mathrm{S} \\
57^{\circ} 18.43^{\prime} \mathrm{E}\end{array}$ & $\begin{array}{l}250.6 \\
200.7\end{array}$ & 72 & $\begin{array}{l}0.3 / 0.1 \\
1.5 / 1.3\end{array}$ & $\begin{array}{l}300.0 \\
115.4\end{array}$ \\
\hline 4 (PL27) & $18 / 11 / 09$ & 2 & $\begin{array}{l}21.44 .35 \\
21.48 .54\end{array}$ & $\begin{array}{l}32^{\circ} 43.28^{\prime} \mathrm{S} \\
57^{\circ} 18.43^{\prime} \mathrm{E}\end{array}$ & $\begin{array}{l}32^{\circ} 43.32^{\prime} \mathrm{S} \\
57^{\circ} 18.61^{\prime} \mathrm{E}\end{array}$ & $\begin{array}{l}200.5 \\
150.1\end{array}$ & 86 & $\begin{array}{l}1.3 / 1.1 \\
1.4 / 1.3\end{array}$ & $\begin{array}{l}118.2 \\
107.7\end{array}$ \\
\hline 4 (PL27) & $18 / 11 / 09$ & 3 & $\begin{array}{l}21.48 .55 \\
21.56 .18\end{array}$ & $\begin{array}{l}32^{\circ} 43.32^{\prime} \mathrm{S} \\
57^{\circ} 18.61^{\prime} \mathrm{E}\end{array}$ & $\begin{array}{l}32^{\circ} 43.40^{\prime} \mathrm{S} \\
57^{\circ} 18.92^{\prime} \mathrm{E}\end{array}$ & $\begin{array}{l}150.4 \\
100.1\end{array}$ & 150 & $\begin{array}{l}0.8 / 0.1 \\
1.7 / 1.6\end{array}$ & $\begin{array}{l}80.0 \\
106.2\end{array}$ \\
\hline 4 (PL27) & $18 / 11 / 09$ & 4 & $\begin{array}{l}21.56 .19 \\
22.01 .49\end{array}$ & $\begin{array}{l}32^{\circ} 43.40^{\prime} \mathrm{S} \\
57^{\circ} 18.92^{\prime} \mathrm{E}\end{array}$ & $\begin{array}{l}32^{\circ} 43.47^{\prime} \mathrm{S} \\
57^{\circ} 19.19^{\prime} \mathrm{E}\end{array}$ & $\begin{array}{l}99.8 \\
50.0\end{array}$ & 151 & $\begin{array}{l}1.8 / 1.6 \\
2.0 / 1.7\end{array}$ & $\begin{array}{l}112.5 \\
117.6\end{array}$ \\
\hline 4 (PL27) & $18 / 11 / 09$ & 5 & $\begin{array}{l}22.01 .50 \\
22.06 .27 \\
\end{array}$ & $\begin{array}{l}32^{\circ} 43.47^{\prime} \mathrm{S} \\
57^{\circ} 19.19^{\prime} \mathrm{E}\end{array}$ & $\begin{array}{l}32^{\circ} 43^{\prime} 53^{\prime} \mathrm{S} \\
57^{\circ} 19.37^{\prime} \mathrm{E}\end{array}$ & $\begin{array}{l}49.7 \\
2.1 \\
\end{array}$ & 125 & $\begin{array}{l}1.8 / 1.7 \\
1.0 / 1.2\end{array}$ & $\begin{array}{l}105.9 \\
83.3\end{array}$ \\
\hline 4 (PL28) & $18 / 11 / 09$ & 1 & $\begin{array}{l}22.35 .48 \\
22.38 .27\end{array}$ & $\begin{array}{l}32^{\circ} 43.94^{\prime} \mathrm{S} \\
57^{\circ} 19.47^{\prime} \mathrm{E}\end{array}$ & $\begin{array}{l}32^{\circ} 43.97^{\prime} \mathrm{S} \\
57^{\circ} 19.37^{\prime} \mathrm{E}\end{array}$ & $\begin{array}{l}199.4 \\
150.4\end{array}$ & 53 & $\begin{array}{l}1.4 / 0.8 \\
1.2 / 1.1\end{array}$ & $\begin{array}{l}175.0 \\
109.1\end{array}$ \\
\hline 4 (PL28) & $18 / 11 / 09$ & 2 & $\begin{array}{l}22.38 .28 \\
22.43 .05 \\
\end{array}$ & $\begin{array}{l}32^{\circ} 43.97^{\prime} \mathrm{S} \\
57^{\circ} 19.37^{\prime} \mathrm{E}\end{array}$ & $\begin{array}{l}32^{\circ} 44.02^{\prime} \mathrm{S} \\
57^{\circ} 19.14^{\prime} \mathrm{E}\end{array}$ & $\begin{array}{l}150.1 \\
100.0\end{array}$ & 90 & $\begin{array}{l}1.4 / 1.0 \\
0.3 / 0.2 \\
\end{array}$ & $\begin{array}{l}140.0 \\
150.0\end{array}$ \\
\hline 4 (PL28) & $18 / 11 / 09$ & 3 & $\begin{array}{l}22.43 .06 \\
22.50 .33\end{array}$ & $\begin{array}{l}32^{\circ} 44.02^{\prime} \mathrm{S} \\
57^{\circ} 19.14^{\prime} \mathrm{E}\end{array}$ & $\begin{array}{l}32^{\circ} 44.13^{\prime} \mathrm{S} \\
57^{\circ} 18.74^{\prime} \mathrm{E}\end{array}$ & $\begin{array}{l}100.3 \\
50.8\end{array}$ & 187 & $\begin{array}{l}0.8 / 0.5 \\
1.2 / 1.4\end{array}$ & $\begin{array}{l}160.0 \\
85.7\end{array}$ \\
\hline 4 (PL28) & $18 / 11 / 09$ & 4 & $\begin{array}{l}22.50 .34 \\
22.52 .52 \\
\end{array}$ & $\begin{array}{l}32^{\circ} 44.13^{\prime} \mathrm{S} \\
57^{\circ} 18.74^{\prime} \mathrm{E}\end{array}$ & $\begin{array}{l}32^{\circ} 44.15^{\prime} \mathrm{S} \\
57^{\circ} 18.66^{\prime} \mathrm{E}\end{array}$ & $\begin{array}{l}50.9 \\
24.8 \\
\end{array}$ & 51 & $\begin{array}{l}1.2 / 1.2 \\
1.4 / 1.5 \\
\end{array}$ & $\begin{array}{l}100.0 \\
93.3 \\
\end{array}$ \\
\hline 4 (PL28) & $18 / 11 / 09$ & 5 & $\begin{array}{l}22.52 .53 \\
22.54 .52 \\
\end{array}$ & $\begin{array}{l}32^{\circ} 44.15^{\prime} \mathrm{S} \\
57^{\circ} 18.66^{\prime} \mathrm{E}\end{array}$ & $\begin{array}{l}32^{\circ} 44.17^{\prime} \mathrm{S} \\
57^{\circ} 18.58^{\prime} \mathrm{E}\end{array}$ & $\begin{array}{l}24.9 \\
0.4\end{array}$ & 44 & $\begin{array}{l}1.1 / 1.2 \\
1.0 / 1.0\end{array}$ & $\begin{array}{l}91.7 \\
100.0 \\
\end{array}$ \\
\hline 4 (PL29) & $19 / 11 / 09$ & 1 & $\begin{array}{l}08.26 .30 \\
08.30 .06 \\
\end{array}$ & $\begin{array}{l}32^{\circ} 48.17^{\prime} \mathrm{S} \\
57^{\circ} 16.77^{\prime} \mathrm{E}\end{array}$ & $\begin{array}{l}32^{\circ} 48.59^{\prime} \mathrm{S} \\
57^{\circ} 16.27^{\prime} \mathrm{E}\end{array}$ & $\begin{array}{l}251.3 \\
200.6\end{array}$ & 56 & $\begin{array}{l}0.8 / 0.1 \\
0.9 / 0.2 \\
\end{array}$ & $\begin{array}{l}800.0 \\
450.0\end{array}$ \\
\hline 4 (PL29) & $19 / 11 / 09$ & 2 & $\begin{array}{l}08.30 .07 \\
08.36 .39 \\
\end{array}$ & $\begin{array}{l}32^{\circ} 48.59^{\prime} \mathrm{S} \\
57^{\circ} 16.27^{\prime} \mathrm{E}\end{array}$ & $\begin{array}{l}32^{\circ} 49.32^{\prime} \mathrm{S} \\
57^{\circ} 15.41^{\prime} \mathrm{E}\end{array}$ & $\begin{array}{l}200.7 \\
149.2 \\
\end{array}$ & 142 & $\begin{array}{l}1.0 / 0.2 \\
1.5 / 1.4 \\
\end{array}$ & $\begin{array}{l}500.0 \\
107.1 \\
\end{array}$ \\
\hline 4 (PL29) & $19 / 11 / 09$ & 3 & $\begin{array}{l}08.36 .40 \\
08.41 .53\end{array}$ & $\begin{array}{l}32^{\circ} 49.32^{\prime} \mathrm{S} \\
57^{\circ} 15.41^{\prime} \mathrm{E}\end{array}$ & $\begin{array}{l}32^{\circ} 48.63^{\prime} \mathrm{S} \\
57^{\circ} 15.48^{\prime} \mathrm{E}\end{array}$ & $\begin{array}{l}148.5 \\
100.1 \\
\end{array}$ & 122 & $\begin{array}{l}1.8 / 1.7 \\
1.2 / 1.4 \\
\end{array}$ & $\begin{array}{l}105.9 \\
85.7\end{array}$ \\
\hline 4 (PL29) & $19 / 11 / 09$ & 4 & $\begin{array}{l}08.41 .54 \\
08.45 .30 \\
\end{array}$ & $\begin{array}{l}32^{\circ} 48.63^{\prime} \mathrm{S} \\
57^{\circ} 15.48^{\prime} \mathrm{E}\end{array}$ & $\begin{array}{l}32^{\circ} 48.19^{\prime} \mathrm{S} \\
57^{\circ} 15.56^{\prime} \mathrm{E}\end{array}$ & $\begin{array}{l}100.3 \\
50.7 \\
\end{array}$ & 87 & $\begin{array}{l}1.0 / 1.1 \\
1.6 / 1.6\end{array}$ & $\begin{array}{l}90.9 \\
100.0 \\
\end{array}$ \\
\hline 4 (PL29) & $19 / 11 / 09$ & 5 & $\begin{array}{l}08.45 .31 \\
08.48 .23\end{array}$ & $\begin{array}{l}32^{\circ} 48.19^{\prime} \mathrm{S} \\
57^{\circ} 15.56^{\prime} \mathrm{E}\end{array}$ & $\begin{array}{l}32^{\circ} 47.75^{\prime} \mathrm{S} \\
57^{\circ} 15.66^{\prime} \mathrm{E}\end{array}$ & $\begin{array}{l}50.8 \\
0.0\end{array}$ & 60 & $\begin{array}{l}1.3 / 1.4 \\
1.6 / 0.9\end{array}$ & $\begin{array}{l}92.9 \\
177.8\end{array}$ \\
\hline 4 (PL30) & $19 / 11 / 09$ & 1 & $\begin{array}{l}09.17 .13 \\
09.21 .56\end{array}$ & $\begin{array}{l}32^{\circ} 45.03^{\prime} \mathrm{S} \\
57^{\circ} 16.32^{\prime} \mathrm{E}\end{array}$ & $\begin{array}{l}32^{\circ} 44.76^{\prime} \mathrm{S} \\
57^{\circ} 16.27^{\prime} \mathrm{E}\end{array}$ & $\begin{array}{l}201.3 \\
150.8\end{array}$ & 86 & $\begin{array}{l}0.5 / 0.1 \\
0.9 / 1.0\end{array}$ & $\begin{array}{l}500.0 \\
90.0\end{array}$ \\
\hline 4 (PL30) & $19 / 11 / 09$ & 2 & $\begin{array}{r}09.21 .57 \\
09.27 .09\end{array}$ & $\begin{array}{l}32^{\circ} 44.76^{\prime} \mathrm{S} \\
57^{\circ} 16.27^{\prime} \mathrm{E}\end{array}$ & $\begin{array}{l}32^{\circ} 44.63^{\prime} \mathrm{S} \\
57^{\circ} 16.16^{\prime} \mathrm{E}\end{array}$ & $\begin{array}{l}151.1 \\
100.5\end{array}$ & 94 & $\begin{array}{l}0.8 / 0.8 \\
0.5 / 0.9\end{array}$ & $\begin{array}{l}100.0 \\
55.6\end{array}$ \\
\hline 4 (PL30) & $19 / 11 / 09$ & 3 & $\begin{array}{l}09.27 .10 \\
09.31 .35\end{array}$ & $\begin{array}{l}32^{\circ} 44.63^{\prime} \mathrm{S} \\
57^{\circ} 16.16^{\prime} \mathrm{E}\end{array}$ & $\begin{array}{l}32^{\circ} 44.52^{\prime} \mathrm{S} \\
57^{\circ} 15.98^{\prime} \mathrm{E}\end{array}$ & $\begin{array}{l}101.1 \\
50.8\end{array}$ & 93 & $\begin{array}{l}0.3 / 0.5 \\
1.3 / 1.4\end{array}$ & $\begin{array}{l}60.0 \\
92.9\end{array}$ \\
\hline 4 (PL30) & $19 / 11 / 09$ & 4 & $\begin{array}{l}09.31 .36 \\
09.33 .39 \\
\end{array}$ & $\begin{array}{l}32^{\circ} 44.52^{\prime} \mathrm{S} \\
57^{\circ} 15.98^{\prime} \mathrm{E}\end{array}$ & $\begin{array}{l}32^{\circ} 44.47^{\prime} \mathrm{S} \\
57^{\circ} 15.91{ }^{\prime} \mathrm{E}\end{array}$ & $\begin{array}{l}50.2 \\
25.1\end{array}$ & 51 & $\begin{array}{l}1.8 / 1.5 \\
1.6 / 1.6\end{array}$ & $\begin{array}{l}120.0 \\
100.0\end{array}$ \\
\hline 4 (PL30) & $19 / 11 / 09$ & 5 & \begin{tabular}{l|}
09.33 .40 \\
09.35 .20 \\
\end{tabular} & $\begin{array}{l}32^{\circ} 44.47^{\prime} \mathrm{S} \\
57^{\circ} 15.91^{\prime} \mathrm{E}\end{array}$ & $\begin{array}{l}32^{\circ} 44.45^{\prime} \mathrm{S} \\
57^{\circ} 15.87^{\prime} \mathrm{E}\end{array}$ & $\begin{array}{l}25.0 \\
0.1 \\
\end{array}$ & 40 & $\begin{array}{l}1.4 / 1.4 \\
1.6 / 1.4 \\
\end{array}$ & $\begin{array}{l}100.0 \\
114.3 \\
\end{array}$ \\
\hline 5 (PL44) & $21 / 11 / 09$ & 1 & $\begin{array}{l}22.16 .10 \\
22.19 .47\end{array}$ & $\begin{array}{l}36^{\circ} 47.44^{\prime} \mathrm{S} \\
52^{\circ} 06.00^{\prime} \mathrm{E}\end{array}$ & $\begin{array}{l}36^{\circ} 47.29^{\prime} \mathrm{S} \\
52^{\circ} 06.05^{\prime} \mathrm{E}\end{array}$ & $\begin{array}{l}200.0 \\
150.2\end{array}$ & 71 & $\begin{array}{l}0.7 / 0.1 \\
1.0 / 1.0\end{array}$ & $\begin{array}{l}700.0 \\
100.0\end{array}$ \\
\hline 5 (PL44) & $21 / 11 / 09$ & 2 & \begin{tabular}{l|}
22.19 .48 \\
22.27 .07 \\
\end{tabular} & $\begin{array}{l}36^{\circ} 47.29^{\prime} \mathrm{S} \\
52^{\circ} 06.05^{\prime} \mathrm{E}\end{array}$ & $\begin{array}{l}36^{\circ} 47.18^{\prime} \mathrm{S} \\
52^{\circ} 06.43^{\prime} \mathrm{E}\end{array}$ & $\begin{array}{l}149.8 \\
101.9 \\
\end{array}$ & 155 & $\begin{array}{l}1.0 / 1.0 \\
1.0 / 1.1 \\
\end{array}$ & $\begin{array}{l}100.0 \\
90.9 \\
\end{array}$ \\
\hline 5 (PL44) & $21 / 11 / 09$ & 3 & $\begin{array}{l}22.27 .08 \\
22.32 .26\end{array}$ & $\begin{array}{l}36^{\circ} 47.18^{\prime} \mathrm{S} \\
52^{\circ} 06.43^{\prime} \mathrm{E}\end{array}$ & $\begin{array}{l}36^{\circ} 47.32^{\prime} \mathrm{S} \\
52^{\circ} 06.66^{\prime} \mathrm{E}\end{array}$ & $\begin{array}{l}101.4 \\
50.5\end{array}$ & 112 & $\begin{array}{l}1.5 / 1.2 \\
1.0 / 1.0\end{array}$ & $\begin{array}{l}125.0 \\
100.0\end{array}$ \\
\hline 5 (PL44) & $21 / 11 / 09$ & 4 & $\begin{array}{l}22.32 .27 \\
22.34 .32\end{array}$ & $\begin{array}{l}36^{\circ} 47.32^{\prime} \mathrm{S} \\
52^{\circ} 06.66^{\prime} \mathrm{E}\end{array}$ & $\begin{array}{l}36^{\circ} 47.42^{\prime} \mathrm{S} \\
52^{\circ} 06.76^{\prime} \mathrm{E}\end{array}$ & $\begin{array}{l}50.5 \\
25.1\end{array}$ & 39 & $\begin{array}{l}1.2 / 1.0 \\
0.8 / 1.2\end{array}$ & $\begin{array}{l}120.0 \\
66.7\end{array}$ \\
\hline 5 (PL44) & $21 / 11 / 09$ & 5 & $\begin{array}{l}22.34 .33 \\
22.36 .21 \\
\end{array}$ & $\begin{array}{l}36^{\circ} 47.42^{\prime} \mathrm{S} \\
52^{\circ} 06.76^{\prime} \mathrm{E}\end{array}$ & $\begin{array}{l}36^{\circ} 47.45^{\prime} \mathrm{S} \\
52^{\circ} 06.79^{\prime} \mathrm{E}\end{array}$ & $\begin{array}{l}25.4 \\
1.1 \\
\end{array}$ & 39 & $\begin{array}{l}0.5 / 0.9 \\
1.6 / 1.4\end{array}$ & $\begin{array}{l}55.6 \\
114.3\end{array}$ \\
\hline 5 (PL45) & $21 / 11 / 09$ & 1 & $\begin{array}{l}22.57 .13 \\
23.00 .43\end{array}$ & $\begin{array}{l}36^{\circ} 48.02^{\prime} \mathrm{S} \\
52^{\circ} 07.38^{\prime} \mathrm{E}\end{array}$ & $\begin{array}{l}36^{\circ} 48.13^{\prime} \mathrm{S} \\
52^{\circ} 07.50^{\prime} \mathrm{E}\end{array}$ & $\begin{array}{l}248.4 \\
200.1\end{array}$ & 71 & $\begin{array}{l}0.5 / 0.4 \\
1.8 / 1.6\end{array}$ & $\begin{array}{l}125.0 \\
112.5\end{array}$ \\
\hline 5 (PL45) & $21 / 11 / 09$ & 2 & $\begin{array}{l}23.00 .44 \\
23.05 .36 \\
\end{array}$ & $\begin{array}{l}36^{\circ} 48.13^{\prime} \mathrm{S} \\
52^{\circ} 07.50^{\prime} \mathrm{E}\end{array}$ & $\begin{array}{l}36^{\circ} 48.27^{\prime} \mathrm{S} \\
52^{\circ} 07.62^{\prime} \mathrm{E}\end{array}$ & $\begin{array}{l}199.6 \\
151.1 \\
\end{array}$ & 104 & $\begin{array}{l}1.8 / 1.6 \\
0.6 / 1.1 \\
\end{array}$ & $\begin{array}{l}112.5 \\
54.5 \\
\end{array}$ \\
\hline 5 (PL45) & $21 / 11 / 09$ & 3 & $\begin{array}{l}23.05 .37 \\
23.09 .05\end{array}$ & $\begin{array}{l}36^{\circ} 48.27^{\prime} \mathrm{S} \\
52^{\circ} 07.62^{\prime} \mathrm{E}\end{array}$ & $\begin{array}{l}36^{\circ} 48.33^{\prime} \mathrm{S} \\
52^{\circ} 07.70^{\prime} \mathrm{E}\end{array}$ & $\begin{array}{l}150.7 \\
100.2\end{array}$ & 79 & $\begin{array}{l}1.2 / 1.3 \\
2.1 / 1.4\end{array}$ & $\begin{array}{l}92.3 \\
150.0\end{array}$ \\
\hline 5 (PL45) & $21 / 11 / 09$ & 4 & $\begin{array}{l}23.09 .06 \\
23.12 .31\end{array}$ & $\begin{array}{l}36^{\circ} 48.33^{\prime} \mathrm{S} \\
52^{\circ} 07.70^{\prime} \mathrm{E}\end{array}$ & $\begin{array}{l}36^{\circ} 48.44^{\prime} \mathrm{S} \\
52^{\circ} 07.80^{\prime} \mathrm{E}\end{array}$ & $\begin{array}{l}99.5 \\
50.5\end{array}$ & 83 & $\begin{array}{l}2.2 / 1.7 \\
1.6 / 1.4\end{array}$ & $\begin{array}{l}129.4 \\
114.3 \\
\end{array}$ \\
\hline 5 (PL45) & $21 / 11 / 09$ & 5 & $\begin{array}{l}23.12 .32 \\
23.15 .19\end{array}$ & $\begin{array}{l}36^{\circ} 48.44^{\prime} \mathrm{S} \\
52^{\circ} 07.80^{\prime} \mathrm{E}\end{array}$ & $\begin{array}{l}36^{\circ} 48.49^{\prime} \mathrm{S} \\
52^{\circ} 07.86^{\prime} \mathrm{E}\end{array}$ & $\begin{array}{l}50.1 \\
0.2\end{array}$ & 62 & $\begin{array}{l}1.8 / 1.5 \\
1.8 / 2.0\end{array}$ & $\begin{array}{l}120.0 \\
90.0\end{array}$ \\
\hline 5 (PL46) & $22 / 11 / 09$ & 1 & $\begin{array}{l}11.27 .08 \\
11.29 .42 \\
\end{array}$ & $\begin{array}{l}36^{\circ} 50.76^{\prime} \mathrm{S} \\
52^{\circ} 03.39^{\prime} \mathrm{E}\end{array}$ & $\begin{array}{l}36^{\circ} 50.87^{\prime} \mathrm{S} \\
52^{\circ} 03.35^{\prime} \mathrm{E}\end{array}$ & $\begin{array}{l}199.6 \\
149.8 \\
\end{array}$ & 38 & $\begin{array}{l}1.9 / 1.5 \\
1.4 / 0.3\end{array}$ & $\begin{array}{l}126.7 \\
466.7\end{array}$ \\
\hline 5 (PL46) & $22 / 11 / 09$ & 2 & 11.29 .43 & $36^{\circ} 50.87^{\prime} \mathrm{S}$ & $36^{\circ} 51.07^{\prime} \mathrm{S}$ & 149.6 & 108 & $1.0 / 0.3$ & 333.3 \\
\hline
\end{tabular}




\begin{tabular}{|c|c|c|c|c|c|c|c|c|c|}
\hline & & & 11.34 .58 & $52^{\circ} 03.35^{\prime} \mathrm{E}$ & $52^{\circ} 03.28^{\prime} \mathrm{E}$ & 100.3 & & $1.7 / 1.4$ & 121.4 \\
\hline 5 (PL46) & $22 / 11 / 09$ & 3 & $\begin{array}{l}11.34 .59 \\
11.40 .20\end{array}$ & $\begin{array}{l}36^{\circ} 51.07^{\prime} \mathrm{S} \\
52^{\circ} 03.28^{\prime} \mathrm{E}\end{array}$ & $\begin{array}{l}36^{\circ} 51.27^{\prime} \mathrm{S} \\
52^{\circ} 03.21^{\prime} \mathrm{E}\end{array}$ & $\begin{array}{l}100.1 \\
50.3\end{array}$ & 107 & $\begin{array}{l}1.5 / 1.5 \\
0.8 / 1.5\end{array}$ & $\begin{array}{l}100.0 \\
53.3\end{array}$ \\
\hline 5 (PL46) & $22 / 11 / 09$ & 4 & $\begin{array}{l}11.40 .21 \\
11.42 .19\end{array}$ & $\begin{array}{l}36^{\circ} 51.27^{\prime} \mathrm{S} \\
52^{\circ} 03.21^{\prime} \mathrm{E}\end{array}$ & $\begin{array}{l}36^{\circ} 51.34^{\prime} \mathrm{S} \\
52^{\circ} 03.18^{\prime} \mathrm{E}\end{array}$ & $\begin{array}{l}50.0 \\
25.8\end{array}$ & 39 & $\begin{array}{l}1.0 / 1.6 \\
1.0 / 1.0\end{array}$ & $\begin{array}{l}62.5 \\
100.0\end{array}$ \\
\hline 5 (PL46) & $22 / 11 / 09$ & 5 & $\begin{array}{l}11.42 .20 \\
11.44 .07 \\
\end{array}$ & $\begin{array}{l}36^{\circ} 51.34^{\prime} \mathrm{S} \\
52^{\circ} 03.18^{\prime} \mathrm{E}\end{array}$ & $\begin{array}{l}36^{\circ} 51.42^{\prime} \mathrm{S} \\
52^{\circ} 03.16^{\prime} \mathrm{E}\end{array}$ & $\begin{array}{l}25.6 \\
1.2 \\
\end{array}$ & 39 & $\begin{array}{l}1.1 / 1.0 \\
1.3 / 1.2 \\
\end{array}$ & $\begin{array}{l}110.0 \\
108.3 \\
\end{array}$ \\
\hline 5 (PL47) & $22 / 11 / 09$ & 1 & $\begin{array}{l}12.05 .50 \\
12.08 .34 \\
\end{array}$ & $\begin{array}{l}36^{\circ} 52.32^{\prime} \mathrm{S} \\
52^{\circ} 03.23^{\prime} \mathrm{E}\end{array}$ & $\begin{array}{l}36^{\circ} 52.45^{\prime} \mathrm{S} \\
52^{\circ} 03.28^{\prime} \mathrm{E} \\
\end{array}$ & $\begin{array}{l}250.9 \\
200.2 \\
\end{array}$ & 49 & $\begin{array}{l}0.9 / 0.8 \\
0.2 / 0.3 \\
\end{array}$ & $\begin{array}{l}112.5 \\
66.7 \\
\end{array}$ \\
\hline 5 (PL47) & $22 / 11 / 09$ & 2 & $\begin{array}{l}12.08 .35 \\
12.14 .33 \\
\end{array}$ & $\begin{array}{l}36^{\circ} 52.45^{\prime} \mathrm{S} \\
52^{\circ} 03.28^{\prime} \mathrm{E}\end{array}$ & $\begin{array}{l}36^{\circ} 52.55^{\prime} \mathrm{S} \\
52^{\circ} 03.23^{\prime} \mathrm{E}\end{array}$ & $\begin{array}{l}199.7 \\
150.1 \\
\end{array}$ & 122 & $\begin{array}{l}0.4 / 0.5 \\
1.6 / 1.5 \\
\end{array}$ & $\begin{array}{l}80.0 \\
106.7 \\
\end{array}$ \\
\hline 5 (PL47) & $22 / 11 / 09$ & 3 & $\begin{array}{l}12.14 .34 \\
12.21 .14\end{array}$ & $\begin{array}{l}36^{\circ} 52.55^{\prime} \mathrm{S} \\
52^{\circ} 03.23^{\prime} \mathrm{E}\end{array}$ & $\begin{array}{l}36^{\circ} 52.35^{\prime} \mathrm{S} \\
52^{\circ} 03.27^{\prime} \mathrm{E}\end{array}$ & $\begin{array}{l}150.2 \\
100.8\end{array}$ & 140 & $\begin{array}{l}1.2 / 1.3 \\
1.4 / 1.2\end{array}$ & $\begin{array}{l}92.3 \\
116.7\end{array}$ \\
\hline 5 (PL47) & $22 / 11 / 09$ & 4 & $\begin{array}{l}12.21 .15 \\
12.26 .11 \\
\end{array}$ & $\begin{array}{l}36^{\circ} 52.35^{\prime} \mathrm{S} \\
52^{\circ} 03.27^{\prime} \mathrm{E}\end{array}$ & $\begin{array}{l}36^{\circ} 52.17^{\prime} \mathrm{S} \\
52^{\circ} 03.28^{\prime} \mathrm{E}\end{array}$ & $\begin{array}{l}100.5 \\
50.4 \\
\end{array}$ & 101 & $\begin{array}{l}1.6 / 1.3 \\
1.3 / 1.2 \\
\end{array}$ & $\begin{array}{l}123.1 \\
108.3 \\
\end{array}$ \\
\hline 5 (PL47) & $22 / 11 / 09$ & 5 & $\begin{array}{l}12.26 .12 \\
12.29 .58\end{array}$ & $\begin{array}{l}36^{\circ} 52.17^{\prime} \mathrm{S} \\
52^{\circ} 03.28^{\prime} \mathrm{E}\end{array}$ & $\begin{array}{l}36^{\circ} 52.033^{\prime} \mathrm{S} \\
52^{\circ} 03.30^{\prime} \mathrm{E}\end{array}$ & $\begin{array}{l}50.5 \\
0.9\end{array}$ & 78 & $\begin{array}{l}1.2 / 1.0 \\
1.0 / 1.3\end{array}$ & $\begin{array}{l}120 \\
76.9\end{array}$ \\
\hline 5 (PL48) & $22 / 11 / 09$ & 1 & $\begin{array}{l}12.55 .23 \\
12.58 .47 \\
\end{array}$ & $\begin{array}{l}36^{\circ} 51.13^{\prime} \mathrm{S} \\
52^{\circ} 03.39^{\prime} \mathrm{E}\end{array}$ & $\begin{array}{l}36^{\circ} 50.99^{\prime} \mathrm{S} \\
52^{\circ} 03.40^{\prime} \mathrm{E}\end{array}$ & $\begin{array}{l}251.7 \\
199.8 \\
\end{array}$ & 53 & $\begin{array}{l}1.0 / 1.1 \\
0.5 / 0.8 \\
\end{array}$ & $\begin{array}{l}90.9 \\
62.5 \\
\end{array}$ \\
\hline 5 (PL48) & $22 / 11 / 09$ & 2 & $\begin{array}{l}12.58 .48 \\
13.03 .05 \\
\end{array}$ & $\begin{array}{l}36^{\circ} 50.99^{\prime} \mathrm{S} \\
52^{\circ} 03.40^{\prime} \mathrm{E}\end{array}$ & $\begin{array}{l}36^{\circ} 50.85^{\prime} \mathrm{S} \\
52^{\circ} 03.43^{\prime} \mathrm{E}\end{array}$ & $\begin{array}{l}199.7 \\
159.7 \\
\end{array}$ & 88 & $\begin{array}{l}0.3 / 0.6 \\
1.7 / 1.4\end{array}$ & $\begin{array}{l}50.0 \\
121.4 \\
\end{array}$ \\
\hline 5 (PL48) & $22 / 11 / 09$ & 3 & $\begin{array}{l}13.03 .06 \\
13.05 .06 \\
\end{array}$ & $\begin{array}{l}36^{\circ} 50.85^{\prime} \mathrm{S} \\
52^{\circ} 03.43^{\prime} \mathrm{E}\end{array}$ & $\begin{array}{l}36^{\circ} 50.78^{\prime} \mathrm{S} \\
52^{\circ} 03.44^{\prime} \mathrm{E}\end{array}$ & $\begin{array}{l}159.5 \\
140.0 \\
\end{array}$ & 47 & $\begin{array}{l}1.6 / 1.4 \\
1.4 / 1.3 \\
\end{array}$ & $\begin{array}{l}114.3 \\
107.7 \\
\end{array}$ \\
\hline 5 (PL48) & $22 / 11 / 09$ & 4 & $\begin{array}{l}13.05 .07 \\
13.13 .40 \\
\end{array}$ & $\begin{array}{l}36^{\circ} 50.78^{\prime} \mathrm{S} \\
52^{\circ} 03.44^{\prime} \mathrm{E}\end{array}$ & $\begin{array}{l}36^{\circ} 50.47^{\prime} \mathrm{S} \\
52^{\circ} 03.49^{\prime} \mathrm{E}\end{array}$ & $\begin{array}{l}140.0 \\
49.9 \\
\end{array}$ & 209 & $\begin{array}{l}1.5 / 1.4 \\
1.7 / 1.5\end{array}$ & $\begin{array}{l}107.14 \\
113.3 \\
\end{array}$ \\
\hline 5 (PL48) & $22 / 11 / 09$ & 5 & $\begin{array}{l}13.13 .41 \\
13.17 .54\end{array}$ & $\begin{array}{l}36^{\circ} 50.47^{\prime} \mathrm{S} \\
52^{\circ} 03.49^{\prime} \mathrm{E}\end{array}$ & $\begin{array}{l}36^{\circ} 50.33^{\prime} \mathrm{S} \\
52^{\circ} 03.51^{\prime} \mathrm{E}\end{array}$ & $\begin{array}{l}49.4 \\
0.0\end{array}$ & 86 & $\begin{array}{l}1.9 / 1.6 \\
1.0 / 1.3\end{array}$ & $\begin{array}{l}118.7 \\
76.9\end{array}$ \\
\hline 5 (PL54) & $24 / 11 / 09$ & 1 & $\begin{array}{l}08.52 .28 \\
08.59 .20 \\
\end{array}$ & $\begin{array}{l}36^{\circ} 47.54^{\prime} \mathrm{S} \\
52^{\circ} 09.94^{\prime} \mathrm{E}\end{array}$ & $\begin{array}{l}36^{\circ} 48.34^{\prime} \mathrm{S} \\
52^{\circ} 10.94^{\prime} \mathrm{E}\end{array}$ & $\begin{array}{l}201.0 \\
150.2\end{array}$ & 147 & $\begin{array}{l}1.2 / 0.3 \\
1.0 / 1.4\end{array}$ & $\begin{array}{l}400.0 \\
71.4\end{array}$ \\
\hline 5 (PL54) & $24 / 11 / 09$ & 2 & $\begin{array}{l}08.59 .21 \\
09.06 .49\end{array}$ & $\begin{array}{l}36^{\circ} 48.34^{\prime} \mathrm{S} \\
52^{\circ} 10.94^{\prime} \mathrm{E}\end{array}$ & $\begin{array}{l}36^{\circ} 49.29^{\prime} \mathrm{S} \\
52^{\circ} 12.09^{\prime} \mathrm{E}\end{array}$ & $\begin{array}{l}150.5 \\
101.4\end{array}$ & 222 & $\begin{array}{l}1.2 / 1.3 \\
1.3 / 1.6\end{array}$ & $\begin{array}{l}92.3 \\
81.2\end{array}$ \\
\hline 5 (PL54) & $24 / 11 / 09$ & 3 & $\begin{array}{l}09.06 .50 \\
09.13 .35 \\
\end{array}$ & $\begin{array}{l}36^{\circ} 49.29^{\prime} \mathrm{S} \\
52^{\circ} 12.09^{\prime} \mathrm{E}\end{array}$ & $\begin{array}{l}36^{\circ} 50.13^{\prime} \mathrm{S} \\
52^{\circ} 13.08^{\prime} \mathrm{E}\end{array}$ & $\begin{array}{l}101.6 \\
49.7 \\
\end{array}$ & 221 & $\begin{array}{l}1.2 / 1.5 \\
1.9 / 2.2\end{array}$ & $\begin{array}{l}80.0 \\
86.4\end{array}$ \\
\hline 5 (PL54) & $24 / 11 / 09$ & 4 & $\begin{array}{l}09.13 .36 \\
09.15 .53 \\
\end{array}$ & $\begin{array}{l}36^{\circ} 50.13^{\prime} \mathrm{S} \\
52^{\circ} 13.08^{\prime} \mathrm{E} \\
\end{array}$ & $\begin{array}{l}36^{\circ} 50.37^{\prime} \mathrm{S} \\
52^{\circ} 13.37^{\prime} \mathrm{E} \\
\end{array}$ & $\begin{array}{l}49.5 \\
24.4 \\
\end{array}$ & 75 & $\begin{array}{l}2.1 / 1.9 \\
2.1 / 2.3 \\
\end{array}$ & $\begin{array}{l}110.5 \\
91.3 \\
\end{array}$ \\
\hline 5 (PL54) & $24 / 11 / 09$ & 5 & $\begin{array}{l}09.15 .54 \\
09.17 .36 \\
\end{array}$ & $\begin{array}{l}36^{\circ} 50.37^{\prime} \mathrm{S} \\
52^{\circ} 13.37^{\prime} \mathrm{E}\end{array}$ & $\begin{array}{l}36^{\circ} 50.62^{\prime} \mathrm{S} \\
52^{\circ} 13.65^{\prime} \mathrm{E}\end{array}$ & $\begin{array}{l}25.2 \\
0.5 \\
\end{array}$ & 58 & $\begin{array}{l}2.0 / 1.9 \\
2.1 / 2.3 \\
\end{array}$ & $\begin{array}{l}105.3 \\
91.3 \\
\end{array}$ \\
\hline 5 (PL61) & $24 / 11 / 09$ & 1 & $\begin{array}{l}17.06 .28 \\
17.09 .46\end{array}$ & $\begin{array}{l}36^{\circ} 46.65^{\prime} \mathrm{S} \\
52^{\circ} 03.49^{\prime} \mathrm{E}\end{array}$ & $\begin{array}{l}36^{\circ} 46.66^{\prime} \mathrm{S} \\
52^{\circ} 03.46^{\prime} \mathrm{E}\end{array}$ & $\begin{array}{l}200.1 \\
149.1\end{array}$ & 53 & $\begin{array}{l}1.4 / 1.1 \\
1.0 / 1.2\end{array}$ & $\begin{array}{l}127.3 \\
83.3\end{array}$ \\
\hline 5 (PL61) & $24 / 11 / 09$ & 2 & $\begin{array}{l}17.09 .47 \\
17.14 .00 \\
\end{array}$ & $\begin{array}{l}36^{\circ} 46.66^{\prime} \mathrm{S} \\
52^{\circ} 03.46^{\prime} \mathrm{E}\end{array}$ & $\begin{array}{l}36^{\circ} 46.67^{\prime} \mathrm{S} \\
52^{\circ} 03.44^{\prime} \mathrm{E}\end{array}$ & $\begin{array}{l}149.0 \\
100.3 \\
\end{array}$ & 83 & $\begin{array}{l}1.2 / 1.1 \\
1.4 / 1.2\end{array}$ & $\begin{array}{l}109.1 \\
116.7\end{array}$ \\
\hline 5 (PL61) & $24 / 11 / 09$ & 3 & \begin{tabular}{|l|}
17.14 .01 \\
17.18 .08 \\
\end{tabular} & $\begin{array}{l}36^{\circ} 46.67^{\prime} \mathrm{S} \\
52^{\circ} 03.44^{\prime} \mathrm{E}\end{array}$ & $\begin{array}{l}36^{\circ} 46.67^{\prime} \mathrm{S} \\
52^{\circ} 03.45^{\prime} \mathrm{E}\end{array}$ & $\begin{array}{l}100.3 \\
50.3 \\
\end{array}$ & 85 & $\begin{array}{l}1.3 / 1.2 \\
0.8 / 1.0\end{array}$ & $\begin{array}{l}108.3 \\
80.0\end{array}$ \\
\hline 5 (PL61) & $24 / 11 / 09$ & 4 & $\begin{array}{l}17.18 .09 \\
17.19 .51 \\
\end{array}$ & $\begin{array}{l}36^{\circ} 46.67^{\prime} \mathrm{S} \\
52^{\circ} 03.45^{\prime} \mathrm{E}\end{array}$ & $\begin{array}{l}36^{\circ} 46.67^{\prime} \mathrm{S} \\
52^{\circ} 03.45^{\prime} \mathrm{E}\end{array}$ & $\begin{array}{l}50.5 \\
24.0 \\
\end{array}$ & 35 & $\begin{array}{l}1.0 / 0.9 \\
1.2 / 1.6\end{array}$ & $\begin{array}{l}11.1 \\
75.0 \\
\end{array}$ \\
\hline 5 (PL61) & $24 / 11 / 09$ & 5 & $\begin{array}{l}17.19 .52 \\
17.22 .59 \\
\end{array}$ & $\begin{array}{l}36^{\circ} 46.67^{\prime} \mathrm{S} \\
52^{\circ} 03.45^{\prime} \mathrm{E}\end{array}$ & $\begin{array}{l}36^{\circ} 46.67^{\prime} \mathrm{S} \\
52^{\circ} 03.45^{\prime} \mathrm{E}\end{array}$ & $\begin{array}{l}24.0 \\
0.2 \\
\end{array}$ & 62 & $\begin{array}{l}1.0 / 1.2 \\
1.6 / 1.4\end{array}$ & $\begin{array}{l}83.3 \\
114.3\end{array}$ \\
\hline 6 (PL66) & $25 / 11 / 09$ & 1 & $\begin{array}{l}13.18 .01 \\
13.20 .53 \\
\end{array}$ & $\begin{array}{l}38^{\circ} 00.12^{\prime} \mathrm{S} \\
50^{\circ} 25.53^{\prime} \mathrm{E}\end{array}$ & $\begin{array}{l}37^{\circ} 59.65^{\prime} \mathrm{S} \\
50^{\circ} 25.35^{\prime} \mathrm{E} \\
\end{array}$ & $\begin{array}{l}200.9 \\
150.2 \\
\end{array}$ & 53 & $\begin{array}{l}0.8 / 0.0 \\
1.2 / 1.3 \\
\end{array}$ & \begin{tabular}{|l|l}
0.0 \\
92.3 \\
\end{tabular} \\
\hline 6 (PL66) & $25 / 11 / 09$ & 2 & $\begin{array}{l}13.20 .54 \\
13.25 .16 \\
\end{array}$ & $\begin{array}{l}37^{0} 59.65^{\prime} \mathrm{S} \\
50^{\circ} 25.35^{\prime} \mathrm{E}\end{array}$ & $\begin{array}{l}37^{\circ} 59.02^{\prime} \mathrm{S} \\
50^{\circ} 25.16^{\prime} \mathrm{E}\end{array}$ & $\begin{array}{l}150.0 \\
99.8 \\
\end{array}$ & 100 & $\begin{array}{l}1.2 / 1.3 \\
1.4 / 1.6\end{array}$ & $\begin{array}{l}92.3 \\
87.5 \\
\end{array}$ \\
\hline 6 (PL66) & $25 / 11 / 09$ & 3 & $\begin{array}{l}13.25 .17 \\
13.29 .23 \\
\end{array}$ & $\begin{array}{l}37^{\circ} 59.02^{\prime} \mathrm{S} \\
50^{\circ} 25.16^{\prime} \mathrm{E}\end{array}$ & $\begin{array}{l}37^{\circ} 58.38^{\prime} \mathrm{S} \\
50^{\circ} 25.00^{\prime} \mathrm{E}\end{array}$ & $\begin{array}{l}99.6 \\
50.5\end{array}$ & 94 & $\begin{array}{l}1.4 / 1.4 \\
1.4 / 1.6\end{array}$ & $\begin{array}{l}100.0 \\
87.5 \\
\end{array}$ \\
\hline 6 (PL66) & $25 / 11 / 09$ & 4 & $\begin{array}{l}13.29 .24 \\
13.31 .10 \\
\end{array}$ & $\begin{array}{l}37^{\circ} 58.38^{\prime} \mathrm{S} \\
50^{\circ} 25.00^{\prime} \mathrm{E}\end{array}$ & $\begin{array}{l}37^{\circ} 58.07^{\prime} \mathrm{S} \\
50^{\circ} 24.93^{\prime} \mathrm{E}\end{array}$ & $\begin{array}{l}50.8 \\
25.8 \\
\end{array}$ & 43 & $\begin{array}{l}1.0 / 1.2 \\
1.4 / 1.2 \\
\end{array}$ & $\begin{array}{l}83.3 \\
116.7 \\
\end{array}$ \\
\hline 6 (PL66) & $25 / 11 / 09$ & 5 & $\begin{array}{l}13.31 .11 \\
13.32 .35\end{array}$ & $\begin{array}{l}37^{\circ} 58.07^{\prime} \mathrm{S} \\
50^{\circ} 24.93^{\prime} \mathrm{E}\end{array}$ & $\begin{array}{l}37^{\circ} 57.77^{\prime} \mathrm{S} \\
50^{\circ} 24.90^{\prime} \mathrm{E}\end{array}$ & $\begin{array}{l}25.3 \\
0.1\end{array}$ & 33 & $\begin{array}{l}1.8 / 1.5 \\
1.8 / 1.2\end{array}$ & $\begin{array}{l}120.0 \\
150.0\end{array}$ \\
\hline 6 (PL67) & $25 / 11 / 09$ & 1 & $\begin{array}{l}13.53 .35 \\
13.56 .13 \\
\end{array}$ & $\begin{array}{l}37^{\circ} 57.54^{\prime} \mathrm{S} \\
50^{\circ} 24.79^{\prime} \mathrm{E}\end{array}$ & $\begin{array}{l}37^{\circ} 57.53^{\prime} \mathrm{S} \\
50^{\circ} 24.79^{\prime} \mathrm{E}\end{array}$ & $\begin{array}{l}249.3 \\
200.6 \\
\end{array}$ & 47 & $\begin{array}{l}0.3 / 0.0 \\
0.8 / 1.0 \\
\end{array}$ & $\begin{array}{l}0.0 \\
80.0 \\
\end{array}$ \\
\hline 6 (PL67) & $25 / 11 / 09$ & 2 & $\begin{array}{l}13.56 .14 \\
14.01 .37 \\
\end{array}$ & $\begin{array}{l}37^{\circ} 57.53^{\prime} \mathrm{S} \\
50^{\circ} 24.79^{\prime} \mathrm{E} \\
\end{array}$ & $\begin{array}{l}37^{\circ} 57.53 ' \mathrm{~S} \\
50^{\circ} 24.80^{\prime} \mathrm{E} \\
\end{array}$ & $\begin{array}{l}200.7 \\
149.7 \\
\end{array}$ & 141 & $\begin{array}{l}0.8 / 0.7 \\
1.8 / 1.6 \\
\end{array}$ & $\begin{array}{l}114.3 \\
112.5 \\
\end{array}$ \\
\hline 6 (PL67) & $25 / 11 / 09$ & 3 & $\begin{array}{l}14.01 .38 \\
14.05 .26\end{array}$ & $\begin{array}{l}37^{\circ} 57.53^{\prime} \mathrm{S} \\
50^{\circ} 24.80^{\prime} \mathrm{E}\end{array}$ & $\begin{array}{l}37^{\circ} 57.51^{\prime} \mathrm{S} \\
50^{\circ} 24.79^{\prime} \mathrm{E}\end{array}$ & $\begin{array}{l}149.5 \\
99.9\end{array}$ & 109 & $\begin{array}{l}2.0 / 1.7 \\
2.3 / 2.1\end{array}$ & $\begin{array}{l}117.6 \\
109.5\end{array}$ \\
\hline 6 (PL67) & $25 / 11 / 09$ & 4 & $\begin{array}{l}14.05 .27 \\
14.08 .38\end{array}$ & $\begin{array}{l}37^{\circ} 57.51^{\prime} \mathrm{S} \\
50^{\circ} 24.79^{\prime} \mathrm{E}\end{array}$ & $\begin{array}{l}37^{\circ} 57.51^{\prime} \mathrm{S} \\
50^{\circ} 24.86^{\prime} \mathrm{E}\end{array}$ & $\begin{array}{l}99.9 \\
49.5 \\
\end{array}$ & 89 & $\begin{array}{l}1.7 / 1.8 \\
2.1 / 2.1\end{array}$ & $\begin{array}{l}94.4 \\
100.0\end{array}$ \\
\hline
\end{tabular}




\begin{tabular}{|c|c|c|c|c|c|c|c|c|c|}
\hline 6 (PL67) & $25 / 11 / 09$ & 5 & $\begin{array}{l}14.08 .39 \\
14.12 .33\end{array}$ & $\begin{array}{l}37^{\circ} 57.51^{\prime} \mathrm{S} \\
50^{\circ} 24.86^{\prime} \mathrm{E}\end{array}$ & $\begin{array}{l}37^{\circ} 57.47^{\prime} \mathrm{S} \\
50^{\circ} 24.69^{\prime} \mathrm{E}\end{array}$ & $\begin{array}{l}49.5 \\
0.7\end{array}$ & 93 & $\begin{array}{l}1.6 / 1.7 \\
1.8 / 1.6\end{array}$ & $\begin{array}{l}94.1 \\
112.5\end{array}$ \\
\hline 6 (PL68) & $25 / 11 / 09$ & 1 & $\begin{array}{l}14.32 .29 \\
14.36 .06\end{array}$ & $\begin{array}{l}37^{\circ} 57.23^{\prime} \mathrm{S} \\
50^{\circ} 24.03^{\prime} \mathrm{E}\end{array}$ & $\begin{array}{l}37^{\circ} 57.14 ' \mathrm{~S} \\
50^{\circ} 23.91 \text { 'E }\end{array}$ & $\begin{array}{l}201.3 \\
151.5\end{array}$ & 64 & $\begin{array}{l}0.3 / 0.3 \\
0.6 / 0.5\end{array}$ & $\begin{array}{l}100.0 \\
120.0\end{array}$ \\
\hline 6 (PL68) & $25 / 11 / 09$ & 2 & $\begin{array}{l}14.36 .07 \\
14.41 .44 \\
\end{array}$ & $\begin{array}{l}37^{\circ} 57.14^{\prime} \mathrm{S} \\
50^{\circ} 23.91^{\prime} \mathrm{E}\end{array}$ & $\begin{array}{l}37^{\circ} 56.99^{\prime} \mathrm{S} \\
50^{\circ} 23.70^{\prime} \mathrm{E}\end{array}$ & $\begin{array}{l}151.3 \\
99.4 \\
\end{array}$ & 128 & $\begin{array}{l}0.8 / 0.7 \\
2.1 / 1.6 \\
\end{array}$ & $\begin{array}{l}114.3 \\
131.2 \\
\end{array}$ \\
\hline 6 (PL68) & $25 / 11 / 09$ & 3 & $\begin{array}{l}14.41 .45 \\
14.46 .15\end{array}$ & $\begin{array}{l}37^{\circ} 56.99^{\prime} \mathrm{S} \\
50^{\circ} 23.70^{\prime} \mathrm{E}\end{array}$ & $\begin{array}{l}37^{\circ} 56.90^{\prime} \mathrm{S} \\
50^{\circ} 23.57^{\prime} \mathrm{E}\end{array}$ & $\begin{array}{l}99.1 \\
50.2\end{array}$ & 102 & $\begin{array}{l}1.8 / 1.7 \\
1.6 / 1.4\end{array}$ & $\begin{array}{l}105.9 \\
114.3\end{array}$ \\
\hline 6 (PL68) & $25 / 11 / 09$ & 4 & $\begin{array}{l}14.46 .16 \\
14.48 .19\end{array}$ & $\begin{array}{l}37^{\circ} 56.90^{\prime} \mathrm{S} \\
50^{\circ} 23.57^{\prime} \mathrm{E}\end{array}$ & $\begin{array}{l}37^{\circ} 56.85^{\prime} \mathrm{S} \\
50^{\circ} 23.51^{\prime} \mathrm{E}\end{array}$ & $\begin{array}{l}49.8 \\
24.6 \\
\end{array}$ & 44 & $\begin{array}{l}1.7 / 1.4 \\
1.2 / 1.4\end{array}$ & $\begin{array}{l}121.4 \\
85.7\end{array}$ \\
\hline 6 (PL68) & $25 / 11 / 09$ & 5 & $\begin{array}{l}14.48 .20 \\
14.51 .14\end{array}$ & $\begin{array}{l}37^{\circ} 56.85^{\prime} \mathrm{S} \\
50^{\circ} 23.51^{\prime} \mathrm{E}\end{array}$ & $\begin{array}{l}37^{\circ} 56.78^{\prime} \mathrm{S} \\
50^{\circ} 23.41^{\prime} \mathrm{E}\end{array}$ & $\begin{array}{l}24.8 \\
2.0\end{array}$ & 64 & $\begin{array}{l}1.0 / 1.2 \\
1.0 / 1.2\end{array}$ & $\begin{array}{l}83.3 \\
83.3\end{array}$ \\
\hline 6 (PL69) & $25 / 11 / 09$ & 1 & $\begin{array}{l}15.25 .03 \\
15.28 .14 \\
\end{array}$ & $\begin{array}{l}37^{\circ} 56.49^{\prime} \mathrm{S} \\
50^{\circ} 22.49^{\prime} \mathrm{E}\end{array}$ & $\begin{array}{l}37^{\circ} 56.61^{\prime} \mathrm{S} \\
50^{\circ} 22.55^{\prime} \mathrm{E}\end{array}$ & $\begin{array}{l}201.2 \\
148.7 \\
\end{array}$ & 58 & $\begin{array}{l}0.8 / 0.6 \\
1.4 / 0.9 \\
\end{array}$ & $\begin{array}{l}133.3 \\
155.6 \\
\end{array}$ \\
\hline 6 (PL69) & $25 / 11 / 09$ & 2 & $\begin{array}{l}15.28 .15 \\
15.33 .11\end{array}$ & $\begin{array}{l}37^{\circ} 56.61 ' \mathrm{~S} \\
50^{\circ} 22.55^{\prime} \mathrm{E}\end{array}$ & $\begin{array}{l}37^{\circ} 56.81^{\prime} \mathrm{S} \\
50^{\circ} 22.65^{\prime} \mathrm{E}\end{array}$ & $\begin{array}{l}148.4 \\
99.6\end{array}$ & 106 & $\begin{array}{l}1.0 / 0.8 \\
1.6 / 1.4\end{array}$ & $\begin{array}{l}125.0 \\
114.3\end{array}$ \\
\hline 6 (PL69) & $25 / 11 / 09$ & 3 & $\begin{array}{l}15.33 .12 \\
15.37 .00\end{array}$ & $\begin{array}{l}37^{\circ} 56.81^{\prime} \mathrm{S} \\
50^{\circ} 22.65^{\prime} \mathrm{E}\end{array}$ & $\begin{array}{l}37^{\circ} 56.97^{\prime} \mathrm{S} \\
50^{\circ} 22.73^{\prime} \mathrm{E}\end{array}$ & $\begin{array}{l}99.2 \\
48.8\end{array}$ & 87 & $\begin{array}{l}1.6 / 1.5 \\
1.7 / 1.7\end{array}$ & $\begin{array}{l}106.7 \\
100.0\end{array}$ \\
\hline 6 (PL69) & $25 / 11 / 09$ & 4 & $\begin{array}{l}15.37 .01 \\
15.40 .07 \\
\end{array}$ & $\begin{array}{l}37^{\circ} 56.97^{\prime} \mathrm{S} \\
50^{\circ} 22.73^{\prime} \mathrm{E}\end{array}$ & $\begin{array}{l}37^{\circ} 57.08^{\prime} \mathrm{S} \\
50^{\circ} 22.79^{\prime} \mathrm{E}\end{array}$ & $\begin{array}{l}48.8 \\
25.2 \\
\end{array}$ & 60 & $\begin{array}{l}1.3 / 1.5 \\
1.1 / 1.0\end{array}$ & $\begin{array}{l}86.7 \\
110.0 \\
\end{array}$ \\
\hline 6 (PL69) & $25 / 11 / 09$ & 5 & $\begin{array}{l}15.40 .08 \\
15.43 .36\end{array}$ & $\begin{array}{l}37^{\circ} 57.08^{\prime} \mathrm{S} \\
50^{\circ} 22.79^{\prime} \mathrm{E}\end{array}$ & $\begin{array}{l}37^{\circ} 57.24^{\prime} \mathrm{S} \\
50^{\circ} 22.87^{\prime} \mathrm{E}\end{array}$ & $\begin{array}{l}25.4 \\
0.1\end{array}$ & 71 & $\begin{array}{l}1.0 / 0.8 \\
1.6 / 1.4\end{array}$ & $\begin{array}{l}125.0 \\
114.3\end{array}$ \\
\hline 6 (PL70) & $25 / 11 / 09$ & 1 & $\begin{array}{l}16.03 .10 \\
16.07 .45 \\
\end{array}$ & $\begin{array}{l}37^{\circ} 57.95^{\prime} \mathrm{S} \\
50^{\circ} 23.62^{\prime} \mathrm{E}\end{array}$ & $\begin{array}{l}37^{\circ} 58.14^{\prime} \mathrm{S} \\
50^{\circ} 23.96^{\prime} \mathrm{E}\end{array}$ & $\begin{array}{l}250.3 \\
200.7\end{array}$ & 75 & $\begin{array}{l}1.1 / 1.0 \\
0.9 / 1.0\end{array}$ & $\begin{array}{l}110.0 \\
90.0\end{array}$ \\
\hline 6 (PL70) & $25 / 11 / 09$ & 2 & $\begin{array}{l}16.07 .46 \\
16.13 .19 \\
\end{array}$ & $\begin{array}{l}37^{\circ} 58.14^{\prime} \mathrm{S} \\
50^{\circ} 23.96^{\prime} \mathrm{E}\end{array}$ & $\begin{array}{l}37^{\circ} 58.28^{\prime} \mathrm{S} \\
50^{\circ} 24.37^{\prime} \mathrm{E}\end{array}$ & $\begin{array}{l}200.9 \\
150.7\end{array}$ & 132 & $\begin{array}{l}1.1 / 1.0 \\
1.4 / 1.4\end{array}$ & $\begin{array}{l}110.0 \\
100.0\end{array}$ \\
\hline 6 (PL70) & $25 / 11 / 09$ & 3 & $\begin{array}{l}16.13 .20 \\
16.17 .03 \\
\end{array}$ & $\begin{array}{l}37^{\circ} 58.28^{\prime} \mathrm{S} \\
50^{\circ} 24.37^{\prime} \mathrm{E}\end{array}$ & $\begin{array}{l}37^{\circ} 58.27^{\prime} \mathrm{S} \\
50^{\circ} 24.58^{\prime} \mathrm{E}\end{array}$ & $\begin{array}{l}150.4 \\
99.8 \\
\end{array}$ & 91 & $\begin{array}{l}1.8 / 1.4 \\
1.4 / 1.3 \\
\end{array}$ & $\begin{array}{l}128.6 \\
107.7 \\
\end{array}$ \\
\hline 6 (PL70) & $25 / 11 / 09$ & 4 & $\begin{array}{l}16.17 .04 \\
16.21 .33\end{array}$ & $\begin{array}{l}37^{\circ} 58.27^{\prime} \mathrm{S} \\
50^{\circ} 24.58^{\prime} \mathrm{E}\end{array}$ & $\begin{array}{l}37^{\circ} 58.09^{\prime} \mathrm{S} \\
50^{\circ} 24.63 \text { 'E }\end{array}$ & $\begin{array}{l}100.1 \\
49.7\end{array}$ & 102 & $\begin{array}{l}0.9 / 1.0 \\
1.6 / 1.6\end{array}$ & $\begin{array}{l}90.0 \\
100.0\end{array}$ \\
\hline 6 (PL70) & $25 / 11 / 09$ & 5 & $\begin{array}{l}16.21 .34 \\
16.24 .39 \\
\end{array}$ & $\begin{array}{l}37^{\circ} 58.09^{\prime} \mathrm{S} \\
50^{\circ} 24.63^{\prime} \mathrm{E}\end{array}$ & $\begin{array}{l}37^{\circ} 57.98^{\prime} \mathrm{S} \\
50^{\circ} 24.63^{\prime} \mathrm{E}\end{array}$ & $\begin{array}{l}49.6 \\
0.4 \\
\end{array}$ & 82 & $\begin{array}{l}1.4 / 1.4 \\
1.8 / 1.8\end{array}$ & $\begin{array}{l}100.0 \\
100.0\end{array}$ \\
\hline 6 (PL71) & $25 / 11 / 09$ & 1 & $\begin{array}{l}16.40 .38 \\
16.44 .38\end{array}$ & $\begin{array}{l}37^{\circ} 57.41^{\prime} \mathrm{S} \\
50^{\circ} 24.58^{\prime} \mathrm{E}\end{array}$ & $\begin{array}{l}37^{\circ} 57.28^{\prime} \mathrm{S} \\
50^{\circ} 24.55^{\prime} \mathrm{E}\end{array}$ & $\begin{array}{l}199.5 \\
150.2\end{array}$ & 60 & $\begin{array}{l}0.8 / 0.3 \\
0.5 / 0.7\end{array}$ & $\begin{array}{l}266.7 \\
71.4\end{array}$ \\
\hline 6 (PL71) & $25 / 11 / 09$ & 2 & $\begin{array}{l}16.44 .39 \\
16.49 .14 \\
\end{array}$ & $\begin{array}{l}37^{\circ} 57.28^{\prime} \mathrm{S} \\
50^{\circ} 24.55^{\prime} \mathrm{E}\end{array}$ & $\begin{array}{l}37^{\circ} 57.15^{\prime} \mathrm{S} \\
50^{\circ} 24.50^{\prime} \mathrm{E}\end{array}$ & $\begin{array}{l}150.0 \\
99.9 \\
\end{array}$ & 95 & $\begin{array}{l}1.2 / 1.0 \\
1.6 / 1.4 \\
\end{array}$ & $\begin{array}{l}120.0 \\
114.3 \\
\end{array}$ \\
\hline 6 (PL71) & $25 / 11 / 09$ & 3 & $\begin{array}{l}16.49 .15 \\
16.52 .42 \\
\end{array}$ & $\begin{array}{l}37^{\circ} 57.15^{\prime} \mathrm{S} \\
50^{\circ} 24.50^{\prime} \mathrm{E}\end{array}$ & $\begin{array}{l}37^{\circ} 57.04^{\prime} \mathrm{S} \\
50^{\circ} 24.42^{\prime} \mathrm{E}\end{array}$ & $\begin{array}{l}99.5 \\
49.4\end{array}$ & 75 & $\begin{array}{l}1.6 / 1.4 \\
1.5 / 1.4\end{array}$ & $\begin{array}{l}114.3 \\
107.1\end{array}$ \\
\hline 6 (PL71) & $25 / 11 / 09$ & 4 & $\begin{array}{l}16.52 .43 \\
16.55 .04 \\
\end{array}$ & $\begin{array}{l}37^{\circ} 57.04^{\prime} \mathrm{S} \\
50^{\circ} 24.42^{\prime} \mathrm{E}\end{array}$ & $\begin{array}{l}37^{\circ} 56.98^{\prime} \mathrm{S} \\
50^{\circ} 24.38^{\prime} \mathrm{E}\end{array}$ & $\begin{array}{l}48.8 \\
25.3 \\
\end{array}$ & 48 & $\begin{array}{l}1.9 / 1.6 \\
0.8 / 1.0 \\
\end{array}$ & $\begin{array}{l}118.75 \\
80.0 \\
\end{array}$ \\
\hline 6 (PL71) & $25 / 11 / 09$ & 5 & $\begin{array}{l}16.55 .05 \\
16.56 .51 \\
\end{array}$ & $\begin{array}{l}37^{\circ} 56.98^{\prime} \mathrm{S} \\
50^{\circ} 24.38^{\prime} \mathrm{E}\end{array}$ & $\begin{array}{l}37^{\circ} 56.91 ' \mathrm{~S} \\
50^{\circ} 24.33^{\prime} \mathrm{E}\end{array}$ & $\begin{array}{l}25.2 \\
0.7 \\
\end{array}$ & 38 & $\begin{array}{l}1.0 / 1.0 \\
0.7 / 1.0 \\
\end{array}$ & $\begin{array}{l}100.0 \\
70.0\end{array}$ \\
\hline 6 (PL82) & $27 / 11 / 09$ & 1 & \begin{tabular}{ll|}
11.13 .51 \\
11.17 .46 \\
\end{tabular} & $\begin{array}{l}37^{\circ} 57.37^{\prime} \mathrm{S} \\
50^{\circ} 25.99^{\prime} \mathrm{E}\end{array}$ & $\begin{array}{l}37^{\circ} 57.41^{\prime} \mathrm{S} \\
50^{\circ} 25.83^{\prime} \mathrm{E}\end{array}$ & $\begin{array}{l}200.0 \\
150.2 \\
\end{array}$ & 62 & $\begin{array}{l}1.0 / 0.8 \\
1.0 / 0.8 \\
\end{array}$ & $\begin{array}{l}125.0 \\
125.0 \\
\end{array}$ \\
\hline 6 (PL82) & $27 / 11 / 09$ & 2 & $\begin{array}{l}11.17 .47 \\
11.23 .51 \\
\end{array}$ & $\begin{array}{l}37^{\circ} 57.41^{\prime} \mathrm{S} \\
50^{\circ} 25.83^{\prime} \mathrm{E}\end{array}$ & $\begin{array}{l}37^{\circ} 57.47^{\prime} \mathrm{S} \\
50^{\circ} 25.61^{\prime} \mathrm{E}\end{array}$ & $\begin{array}{l}150.2 \\
100.6 \\
\end{array}$ & 109 & $\begin{array}{l}1.0 / 0.8 \\
1.2 / 1.1 \\
\end{array}$ & $\begin{array}{l}125.0 \\
109.1\end{array}$ \\
\hline 6 (PL82) & $27 / 11 / 09$ & 3 & $\begin{array}{l}11.23 .52 \\
11.28 .14\end{array}$ & $\begin{array}{l}37^{\circ} 57.47^{\prime} \mathrm{S} \\
50^{\circ} 25.61^{\prime} \mathrm{E}\end{array}$ & $\begin{array}{l}37^{\circ} 57.51^{\prime} \mathrm{S} \\
50^{\circ} 25.46^{\prime} \mathrm{E}\end{array}$ & $\begin{array}{l}100.4 \\
51.0\end{array}$ & 90 & $\begin{array}{l}1.3 / 1.2 \\
1.2 / 1.4\end{array}$ & $\begin{array}{l}108.3 \\
85.7\end{array}$ \\
\hline 6 (PL82) & $27 / 11 / 09$ & 4 & $\begin{array}{l}11.28 .15 \\
11.30 .33 \\
\end{array}$ & $\begin{array}{l}37^{\circ} 57.51^{\prime} \mathrm{S} \\
50^{\circ} 25.46^{\prime} \mathrm{E}\end{array}$ & $\begin{array}{l}37^{\circ} 57.54^{\prime} \mathrm{S} \\
50^{\circ} 25.35^{\prime} \mathrm{E}\end{array}$ & $\begin{array}{l}51.1 \\
25.9 \\
\end{array}$ & 55 & $\begin{array}{l}1.0 / 1.2 \\
1.3 / 1.3\end{array}$ & $\begin{array}{l}83.3 \\
100.0\end{array}$ \\
\hline 6 (PL82) & $27 / 11 / 09$ & 5 & \begin{tabular}{|l|}
11.30 .34 \\
11.31 .59 \\
\end{tabular} & $\begin{array}{l}37^{\circ} 57.54^{\prime} \mathrm{S} \\
50^{\circ} 25.35^{\prime} \mathrm{E}\end{array}$ & $\begin{array}{l}37^{\circ} 57.55^{\prime} \mathrm{S} \\
50^{\circ} 25.32^{\prime} \mathrm{E}\end{array}$ & $\begin{array}{l}25.3 \\
1.2 \\
\end{array}$ & 39 & $\begin{array}{l}2.1 / 1.6 \\
1.4 / 0.3 \\
\end{array}$ & $\begin{array}{l}131.2 \\
466.7 \\
\end{array}$ \\
\hline 7 (PL95) & $29 / 11 / 09$ & 1 & $\begin{array}{l}12.40 .08 \\
12.41 .53 \\
\end{array}$ & $\begin{array}{l}41^{\circ} 29.98^{\prime} \mathrm{S} \\
49^{\circ} 30.28^{\prime} \mathrm{E}\end{array}$ & $\begin{array}{l}1^{\circ} 29.97^{\prime} \mathrm{S} \\
49^{\circ} 30.29^{\prime} \mathrm{E}\end{array}$ & $\begin{array}{l}199.4 \\
149.4 \\
\end{array}$ & 31 & $\begin{array}{l}0.6 / 0.3 \\
1.2 / 0.3 \\
\end{array}$ & $\begin{array}{l}200.0 \\
400.0 \\
\end{array}$ \\
\hline 7 (PL95) & $29 / 11 / 09$ & 2 & $\begin{array}{l}12.41 .54 \\
12.44 .55\end{array}$ & $\begin{array}{l}41^{\circ} 29.97^{\prime} \mathrm{S} \\
49^{\circ} 30.29^{\prime} \mathrm{E}\end{array}$ & $\begin{array}{l}41^{\circ} 29.94^{\prime} \mathrm{S} \\
49^{\circ} 30.30^{\prime} \mathrm{E}\end{array}$ & $\begin{array}{l}149.2 \\
100.4\end{array}$ & 70 & $\begin{array}{l}1.0 / 0.2 \\
1.3 / 1.4\end{array}$ & $\begin{array}{l}500.0 \\
92.9\end{array}$ \\
\hline 7 (PL95) & $29 / 11 / 09$ & 3 & $\begin{array}{l}12.44 .56 \\
12.47 .49 \\
\end{array}$ & $\begin{array}{l}41^{\circ} 29.94^{\prime} \mathrm{S} \\
49^{\circ} 30.30^{\prime} \mathrm{E}\end{array}$ & $\begin{array}{l}41^{\circ} 29.91^{\prime} \mathrm{S} \\
49^{\circ} 30.34^{\prime} \mathrm{E}\end{array}$ & $\begin{array}{l}100.6 \\
49.9 \\
\end{array}$ & 63 & $\begin{array}{l}1.1 / 1.2 \\
1.6 / 1.3 \\
\end{array}$ & $\begin{array}{l}91.7 \\
123.1 \\
\end{array}$ \\
\hline 7 (PL95) & $29 / 11 / 09$ & 4 & $\begin{array}{l}12.47 .50 \\
12.48 .53 \\
\end{array}$ & $\begin{array}{l}41^{\circ} 29.91^{\prime} \mathrm{S} \\
49^{\circ} 30.34^{\prime} \mathrm{E}\end{array}$ & $\begin{array}{l}41^{\circ} 29.91^{\prime} \mathrm{S} \\
49^{\circ} 30.34^{\prime} \mathrm{E}\end{array}$ & $\begin{array}{l}49.4 \\
25.0 \\
\end{array}$ & 21 & $\begin{array}{l}1.6 / 1.4 \\
1.5 / 1.4 \\
\end{array}$ & $\begin{array}{l}114.3 \\
107.1 \\
\end{array}$ \\
\hline 7 (PL95) & $29 / 11 / 09$ & 5 & $\begin{array}{l}12.48 .54 \\
12.49 .54 \\
\end{array}$ & $\begin{array}{l}41^{\circ} 29.91^{\prime} \mathrm{S} \\
49^{\circ} 30.34^{\prime} \mathrm{E} \\
\end{array}$ & $\begin{array}{l}41^{\circ} 29.90^{\prime} \mathrm{S} \\
49^{\circ} 30.33^{\prime} \mathrm{E}\end{array}$ & $\begin{array}{l}24.0 \\
0.4 \\
\end{array}$ & 24 & $\begin{array}{l}2.1 / 1.7 \\
1.4 / 1.4 \\
\end{array}$ & $\begin{array}{l}123.5 \\
100.0 \\
\end{array}$ \\
\hline 7 (PL97) & $29 / 11 / 09$ & 1 & $\begin{array}{l}13.51 .09 \\
13.54 .45\end{array}$ & $\begin{array}{l}41^{\circ} 29.45^{\prime} \mathrm{S} \\
49^{\circ} 31.31^{\prime} \mathrm{E}\end{array}$ & $\begin{array}{l}41^{\circ} 29.40^{\prime} \mathrm{S} \\
49^{\circ} 31.50^{\prime} \mathrm{E}\end{array}$ & $\begin{array}{l}200.3 \\
150.2\end{array}$ & 62 & $\begin{array}{l}0.3 / 0.3 \\
1.4 / 1.2\end{array}$ & $\begin{array}{l}100.0 \\
116.7\end{array}$ \\
\hline 7 (PL97) & $29 / 11 / 09$ & 2 & 13.54 .46 & $41^{\circ} 29.40^{\prime} \mathrm{S}$ & $41^{\circ} 29.37^{\prime} \mathrm{S}$ & 150.3 & 80 & $1.0 / 1.0$ & 100.0 \\
\hline
\end{tabular}




\begin{tabular}{|c|c|c|c|c|c|c|c|c|c|}
\hline & & & 13.58 .30 & $49^{\circ} 31.50^{\prime} \mathrm{E}$ & $49^{\circ} 31.64^{\prime} \mathrm{E}$ & 100.2 & & $1.4 / 1.8$ & 77.8 \\
\hline 7 (PL97) & $29 / 11 / 09$ & 3 & $\begin{array}{l}13.58 .31 \\
14.02 .33\end{array}$ & $\begin{array}{l}41^{\circ} 29.37^{\prime} \mathrm{S} \\
49^{\circ} 31.64^{\prime} \mathrm{E}\end{array}$ & $\begin{array}{l}41^{\circ} 29.33^{\prime} \mathrm{S} \\
49^{\circ} 31.85^{\prime} \mathrm{E}\end{array}$ & $\begin{array}{l}100.5 \\
49.9\end{array}$ & 95 & $\begin{array}{l}1.0 / 1.3 \\
0.9 / 1.1\end{array}$ & $\begin{array}{l}76.9 \\
81.8\end{array}$ \\
\hline 7 (PL97) & $29 / 11 / 09$ & 4 & $\begin{array}{l}14.02 .34 \\
14.04 .23\end{array}$ & $\begin{array}{l}41^{\circ} 29.33^{\prime} \mathrm{S} \\
49^{\circ} 31.85^{\prime} \mathrm{E}\end{array}$ & $\begin{array}{l}41^{\circ} 29.32^{\prime} \mathrm{S} \\
49^{\circ} 31.89^{\prime} \mathrm{E}\end{array}$ & $\begin{array}{l}49.7 \\
25.0\end{array}$ & 40 & $\begin{array}{l}1.1 / 1.1 \\
0.8 / 1.0\end{array}$ & $\begin{array}{l}100.0 \\
80.0\end{array}$ \\
\hline 7 (PL97) & $29 / 11 / 09$ & 5 & $\begin{array}{l}14.04 .24 \\
14.06 .32\end{array}$ & $\begin{array}{l}41^{\circ} 29.32^{\prime} \mathrm{S} \\
49^{\circ} 31.89^{\prime} \mathrm{E}\end{array}$ & $\begin{array}{l}41^{\circ} 29.30^{\prime} \mathrm{S} \\
49^{\circ} 32.01^{\prime} \mathrm{E}\end{array}$ & $\begin{array}{l}25.0 \\
0.0\end{array}$ & 44 & $\begin{array}{l}1.0 / 1.0 \\
1.4 / 1.0\end{array}$ & $\begin{array}{l}100.0 \\
140.0\end{array}$ \\
\hline $\begin{array}{l}7 \\
\text { (PL102) }\end{array}$ & $29 / 11 / 09$ & 1 & $\begin{array}{l}17.20 .31 \\
17.27 .09\end{array}$ & $\begin{array}{l}41^{\circ} 30.49^{\prime} \mathrm{S} \\
49^{\circ} 28.90^{\prime} \mathrm{E}\end{array}$ & $\begin{array}{l}41^{\circ} 30.59^{\prime} \mathrm{S} \\
49^{\circ} 28.63^{\prime} \mathrm{E}\end{array}$ & $\begin{array}{l}200.5 \\
120.3\end{array}$ & 109 & $\begin{array}{l}0.5 / 0.3 \\
1.2 / 1.2\end{array}$ & $\begin{array}{l}166.7 \\
100.0\end{array}$ \\
\hline $\begin{array}{l}7 \\
\text { (PL102) }\end{array}$ & $29 / 11 / 09$ & 2 & $\begin{array}{l}17.27 .10 \\
17.30 .37 \\
\end{array}$ & $\begin{array}{l}41^{\circ} 30.59^{\prime} \mathrm{S} \\
49^{\circ} 28.633^{\prime} \mathrm{E}\end{array}$ & $\begin{array}{l}41^{\circ} 30.65^{\prime} \mathrm{S} \\
49^{\circ} 28.46^{\prime} \mathrm{E} \\
\end{array}$ & $\begin{array}{l}120.3 \\
81.1 \\
\end{array}$ & 58 & $\begin{array}{l}1.0 / 1.0 \\
1.2 / 1.0\end{array}$ & $\begin{array}{l}100.0 \\
120.0 \\
\end{array}$ \\
\hline $\begin{array}{l}7 \\
\text { (PL102) }\end{array}$ & $29 / 11 / 09$ & 3 & $\begin{array}{l}17.30 .38 \\
17.34 .14\end{array}$ & $\begin{array}{l}41^{\circ} 30.65^{\prime} \mathrm{S} \\
49^{\circ} 28.46^{\prime} \mathrm{E}\end{array}$ & $\begin{array}{l}41^{\circ} 30.70^{\prime} \mathrm{S} \\
49^{\circ} 28.33^{\prime} \mathrm{E}\end{array}$ & $\begin{array}{l}80.4 \\
51.4\end{array}$ & 65 & $\begin{array}{l}1.6 / 1.3 \\
0.9 / 0.9\end{array}$ & $\begin{array}{l}123.1 \\
100.0\end{array}$ \\
\hline $\begin{array}{l}7 \\
\text { (PL102) }\end{array}$ & $29 / 11 / 09$ & 4 & $\begin{array}{l}17.34 .15 \\
17.38 .44\end{array}$ & $\begin{array}{l}41^{\circ} 30.70^{\prime} \mathrm{S} \\
49^{\circ} 28.33^{\prime} \mathrm{E}\end{array}$ & $\begin{array}{l}41^{\circ} 30.77^{\prime} \mathrm{S} \\
49^{\circ} 28.11^{\prime} \mathrm{E}\end{array}$ & $\begin{array}{l}51.7 \\
25.9\end{array}$ & 82 & $\begin{array}{l}1.0 / 0.8 \\
0.5 / 0.9\end{array}$ & $\begin{array}{l}125.0 \\
55.6\end{array}$ \\
\hline $\begin{array}{l}7 \\
\text { (PL102) }\end{array}$ & $29 / 11 / 09$ & 5 & $\begin{array}{l}17.38 .45 \\
17.42 .23 \\
\end{array}$ & $\begin{array}{l}41^{\circ} 30.77^{\prime} \mathrm{S} \\
49^{\circ} 28.11^{\prime} \mathrm{E}\end{array}$ & $\begin{array}{l}41^{\circ} 30.81^{\prime} \mathrm{S} \\
49^{\circ} 27.98^{\prime} \mathrm{E}\end{array}$ & $\begin{array}{l}25.8 \\
0.0\end{array}$ & 63 & $\begin{array}{l}1.0 / 0.9 \\
0.5 / 1.3\end{array}$ & $\begin{array}{l}111.1 \\
38.5\end{array}$ \\
\hline $\begin{array}{l}7 \\
\text { (PL103) }\end{array}$ & $29 / 11 / 09$ & 1 & $\begin{array}{l}17.59 .28 \\
18.03 .52\end{array}$ & $\begin{array}{l}41^{\circ} 31.04^{\prime} \mathrm{S} \\
49^{\circ} 27.26^{\prime} \mathrm{E}\end{array}$ & $\begin{array}{l}41^{\circ} 31.12^{\prime} \mathrm{S} \\
49^{\circ} 27.05^{\prime} \mathrm{E}\end{array}$ & $\begin{array}{l}251.1 \\
200.3\end{array}$ & 67 & $\begin{array}{l}1.1 / 0.8 \\
1.1 / 1.0\end{array}$ & $\begin{array}{l}137.5 \\
110.0\end{array}$ \\
\hline $\begin{array}{l}7 \\
\text { (PL103) }\end{array}$ & $29 / 11 / 09$ & 2 & $\begin{array}{l}18.03 .53 \\
18.09 .42 \\
\end{array}$ & $\begin{array}{l}41^{\circ} 31.12^{\prime} \mathrm{S} \\
49^{\circ} 27.05^{\prime} \mathrm{E}\end{array}$ & $\begin{array}{l}41^{\circ} 31.09^{\prime} \mathrm{S} \\
49^{\circ} 26.99^{\prime} \mathrm{E}\end{array}$ & $\begin{array}{l}200.1 \\
151.2 \\
\end{array}$ & 100 & $\begin{array}{l}1.1 / 1.0 \\
0.9 / 1.0\end{array}$ & $\begin{array}{l}110.0 \\
90.0\end{array}$ \\
\hline $\begin{array}{l}7 \\
\text { (PL103) }\end{array}$ & $29 / 11 / 09$ & 3 & $\begin{array}{l}18.09 .43 \\
18.14 .13\end{array}$ & $\begin{array}{l}41^{\circ} 31.09^{\prime} \mathrm{S} \\
49^{\circ} 26.99^{\prime} \mathrm{E}\end{array}$ & $\begin{array}{l}41^{\circ} 31.03 ' \mathrm{~S} \\
49^{\circ} 27.14^{\prime} \mathrm{E}\end{array}$ & $\begin{array}{l}151.5 \\
100.2\end{array}$ & 85 & $\begin{array}{l}0.9 / 0.9 \\
1.4 / 1.4\end{array}$ & $\begin{array}{l}100.0 \\
100.0\end{array}$ \\
\hline $\begin{array}{l}7 \\
\text { (PL103) }\end{array}$ & $29 / 11 / 09$ & 4 & $\begin{array}{l}18.14 .14 \\
18.18 .43 \\
\end{array}$ & $\begin{array}{l}41^{\circ} 31.03^{\prime} \mathrm{S} \\
4^{\circ} 27.14^{\prime} \mathrm{E}\end{array}$ & $\begin{array}{l}41^{\circ} 30.97^{\prime} \mathrm{S} \\
49^{\circ} 27.34^{\prime} \mathrm{E}\end{array}$ & $\begin{array}{l}100.0 \\
50.0 \\
\end{array}$ & 94 & $\begin{array}{l}1.4 / 1.4 \\
0.8 / 1.1 \\
\end{array}$ & $\begin{array}{l}100.0 \\
72.7\end{array}$ \\
\hline $\begin{array}{l}7 \\
\text { (PL103) }\end{array}$ & $29 / 11 / 09$ & 5 & $\begin{array}{l}18.18 .44 \\
18.22 .02\end{array}$ & $\begin{array}{l}41^{\circ} 30.97^{\prime} \mathrm{S} \\
49^{\circ} 27.34^{\prime} \mathrm{E}\end{array}$ & $\begin{array}{l}41^{\circ} 30.93^{\prime} \mathrm{S} \\
49^{\circ} 27.47^{\prime} \mathrm{E}\end{array}$ & $\begin{array}{l}50.2 \\
0.0\end{array}$ & 63 & $\begin{array}{l}0.8 / 1.0 \\
1.5 / 1.4\end{array}$ & $\begin{array}{l}80.0 \\
107.1\end{array}$ \\
\hline $\begin{array}{l}7 \\
\text { (PL104) }\end{array}$ & $29 / 11 / 09$ & 1 & $\begin{array}{l}18.44 .46 \\
18.54 .11 \\
\end{array}$ & $\begin{array}{l}41^{\circ} 30.66^{\prime} \mathrm{S} \\
49^{\circ} 28.44^{\prime} \mathrm{E}\end{array}$ & $\begin{array}{l}41^{\circ} 30.58^{\prime} \mathrm{S} \\
49^{\circ} 28.73^{\prime} \mathrm{E}\end{array}$ & $\begin{array}{l}202.5 \\
80.4\end{array}$ & 138 & $\begin{array}{l}1.4 / 1.2 \\
1.0 / 1.1\end{array}$ & $\begin{array}{l}116.7 \\
90.9\end{array}$ \\
\hline $\begin{array}{l}7 \\
\text { (PL104) }\end{array}$ & $29 / 11 / 09$ & 2 & $\begin{array}{l}18.54 .12 \\
18.56 .24\end{array}$ & $\begin{array}{l}41^{\circ} 30.58^{\prime} \mathrm{S} \\
49^{\circ} 28.73^{\prime} \mathrm{E}\end{array}$ & $\begin{array}{l}41^{\circ} 30.56^{\prime} \mathrm{S} \\
49^{\circ} 28.81^{\prime} \mathrm{E}\end{array}$ & $\begin{array}{l}80.3 \\
50.0\end{array}$ & 45 & $\begin{array}{l}1.1 / 1.1 \\
1.3 / 1.2\end{array}$ & $\begin{array}{l}100.0 \\
108.3\end{array}$ \\
\hline $\begin{array}{l}7 \\
\text { (PL104) }\end{array}$ & $29 / 11 / 09$ & 3 & $\begin{array}{l}18.56 .25 \\
18.59 .50\end{array}$ & $\begin{array}{l}41^{\circ} 30.56^{\prime} \mathrm{S} \\
49^{\circ} 28.81^{\prime} \mathrm{E}\end{array}$ & $\begin{array}{l}41^{\circ} 30.52^{\prime} \mathrm{S} \\
49^{\circ} 28.97^{\prime} \mathrm{E}\end{array}$ & $\begin{array}{l}49.8 \\
25.0\end{array}$ & 65 & $\begin{array}{l}1.4 / 1.2 \\
1.2 / 1.2\end{array}$ & $\begin{array}{l}116.7 \\
100.0\end{array}$ \\
\hline $\begin{array}{l}7 \\
\text { (PL104) }\end{array}$ & $29 / 11 / 09$ & 4 & $\begin{array}{l}18.59 .51 \\
19.02 .48\end{array}$ & $\begin{array}{l}41^{\circ} 30.52^{\prime} \mathrm{S} \\
49^{\circ} 28.97^{\prime} \mathrm{E}\end{array}$ & $\begin{array}{l}41^{\circ} 30.49^{\prime} \mathrm{S} \\
49^{\circ} 29.11^{\prime} \mathrm{E}\end{array}$ & $\begin{array}{l}25.0 \\
0.8\end{array}$ & 46 & $\begin{array}{l}1.2 / 1.0 \\
0.9 / 0.8\end{array}$ & $\begin{array}{l}120.0 \\
112.5 \\
\end{array}$ \\
\hline $\begin{array}{l}8 \\
\text { (PL108) }\end{array}$ & $01 / 12 / 09$ & 1 & $\begin{array}{l}22.37 .59 \\
22.41 .44 \\
\end{array}$ & $\begin{array}{l}41^{\circ} 25.36^{\prime} \mathrm{S} \\
42^{\circ} 51.05^{\prime} \mathrm{E}\end{array}$ & $\begin{array}{l}41^{\circ} 25.43 ' \mathrm{~S} \\
42^{\circ} 50.82^{\prime} \mathrm{E}\end{array}$ & $\begin{array}{l}200.7 \\
150.6 \\
\end{array}$ & 75 & $\begin{array}{l}0.2 / 0.1 \\
1.6 / 1.5\end{array}$ & $\begin{array}{l}200.0 \\
106.7 \\
\end{array}$ \\
\hline $\begin{array}{l}8 \\
\text { (PL108) }\end{array}$ & $01 / 12 / 09$ & 2 & $\begin{array}{l}22.41 .45 \\
22.46 .08 \\
\end{array}$ & $\begin{array}{l}41^{\circ} 25.43^{\prime} \mathrm{S} \\
42^{\circ} 50.82^{\prime} \mathrm{E}\end{array}$ & $\begin{array}{l}41^{\circ} 25.45^{\prime} \mathrm{S} \\
42^{\circ} 50.82^{\prime} \mathrm{E}\end{array}$ & $\begin{array}{l}150.7 \\
100.9\end{array}$ & 97 & $\begin{array}{l}1.3 / 1.4 \\
1.2 / 1.2\end{array}$ & $\begin{array}{l}92.9 \\
100.0\end{array}$ \\
\hline $\begin{array}{l}8 \\
\text { (PL108) }\end{array}$ & $01 / 12 / 09$ & 3 & $\begin{array}{l}22.46 .09 \\
22.49 .25\end{array}$ & $\begin{array}{l}41^{\circ} 25.45^{\prime} \mathrm{S} \\
42^{\circ} 50.82^{\prime} \mathrm{E}\end{array}$ & $\begin{array}{l}41^{\circ} 25.47^{\prime} \mathrm{S} \\
42^{\circ} 50.80^{\prime} \mathrm{E}\end{array}$ & $\begin{array}{l}100.5 \\
50.7\end{array}$ & 66 & $\begin{array}{l}1.4 / 1.2 \\
0.8 / 1.0\end{array}$ & $\begin{array}{l}116.7 \\
80.0\end{array}$ \\
\hline $\begin{array}{l}8 \\
\text { (PL108) }\end{array}$ & $01 / 12 / 09$ & 4 & $\begin{array}{l}22.49 .26 \\
22.50 .38\end{array}$ & $\begin{array}{l}41^{\circ} 25.47^{\prime} \mathrm{S} \\
42^{\circ} 50.80^{\prime} \mathrm{E}\end{array}$ & $\begin{array}{l}41^{\circ} 25.47^{\prime} \mathrm{S} \\
42^{\circ} 50.81^{\prime} \mathrm{E}\end{array}$ & $\begin{array}{l}50.6 \\
24.9\end{array}$ & 23 & $\begin{array}{l}0.8 / 1.0 \\
1.2 / 1.4\end{array}$ & $\begin{array}{l}80.0 \\
85.7\end{array}$ \\
\hline $\begin{array}{l}8 \\
\text { (PL108) }\end{array}$ & $01 / 12 / 09$ & 5 & $\begin{array}{l}22.50 .39 \\
22.51 .37 \\
\end{array}$ & $\begin{array}{l}41^{\circ} 25.47^{\prime} \mathrm{S} \\
42^{\circ} 50.81^{\prime} \mathrm{E}\end{array}$ & $\begin{array}{l}41^{\circ} 25.48^{\prime} \mathrm{S} \\
42^{\circ} 50.81^{\prime} \mathrm{S}\end{array}$ & $\begin{array}{l}24.8 \\
0.0 \\
\end{array}$ & 24 & $\begin{array}{l}1.1 / 1.2 \\
1.6 / 1.6\end{array}$ & $\begin{array}{l}91.7 \\
100.0 \\
\end{array}$ \\
\hline $\begin{array}{l}8 \\
\text { (PL109) }\end{array}$ & $01 / 12 / 09$ & 1 & $\begin{array}{l}23.17 .51 \\
23.24 .46 \\
\end{array}$ & $\begin{array}{l}41^{\circ} 25.90^{\prime} \mathrm{S} \\
42^{\circ} 51.21^{\prime} \mathrm{E}\end{array}$ & $\begin{array}{l}41^{\circ} 26.33^{\prime} \mathrm{S} \\
42^{\circ} 51.41^{\prime} \mathrm{E}\end{array}$ & $\begin{array}{l}250.5 \\
200.3\end{array}$ & 129 & $\begin{array}{l}0.1 / 0.2 \\
0.3 / 0.5\end{array}$ & $\begin{array}{l}50.0 \\
60.0\end{array}$ \\
\hline $\begin{array}{l}8 \\
\text { (PL109) }\end{array}$ & $01 / 12 / 09$ & 2 & $\begin{array}{l}23.24 .47 \\
23.31 .06\end{array}$ & $\begin{array}{l}41^{\circ} 26.33^{\prime} \mathrm{S} \\
42^{\circ} 51.41^{\prime} \mathrm{E}\end{array}$ & $\begin{array}{l}41^{\circ} 26.23^{\prime} \mathrm{S} \\
42^{\circ} 51.69^{\prime} \mathrm{E}\end{array}$ & $\begin{array}{l}200.4 \\
149.5\end{array}$ & 169 & $\begin{array}{l}1.0 / 1.0 \\
2.1 / 2.3\end{array}$ & $\begin{array}{l}100.0 \\
91.3\end{array}$ \\
\hline $\begin{array}{l}8 \\
\text { (PL109) }\end{array}$ & $01 / 12 / 09$ & 3 & $\begin{array}{l}23.31 .07 \\
23.35 .18 \\
\end{array}$ & $\begin{array}{l}41^{\circ} 26.23 ' \mathrm{~S} \\
42^{\circ} 51.69^{\prime} \mathrm{E}\end{array}$ & $\begin{array}{l}41^{\circ} 26.16^{\prime} \mathrm{S} \\
42^{\circ} 51.89^{\prime} \mathrm{E}\end{array}$ & $\begin{array}{l}149.4 \\
100.5 \\
\end{array}$ & 119 & $\begin{array}{l}1.8 / 2.0 \\
1.6 / 1.8\end{array}$ & $\begin{array}{l}90.0 \\
88.9\end{array}$ \\
\hline $\begin{array}{l}8 \\
\text { (PL109) }\end{array}$ & $01 / 12 / 09$ & 4 & $\begin{array}{l}23.35 .19 \\
23.39 .07\end{array}$ & $\begin{array}{l}41^{\circ} 26.16^{\prime} \mathrm{S} \\
42^{\circ} 51.89^{\prime} \mathrm{E}\end{array}$ & $\begin{array}{l}41^{\circ} 26.08^{\prime} \mathrm{S} \\
42^{\circ} 52.10^{\prime} \mathrm{E}\end{array}$ & $\begin{array}{l}100.6 \\
50.2\end{array}$ & 99 & $\begin{array}{l}1.4 / 1.5 \\
1.2 / 1.4\end{array}$ & $\begin{array}{l}93.3 \\
85.7\end{array}$ \\
\hline $\begin{array}{l}8 \\
\text { (PL109) }\end{array}$ & $01 / 12 / 09$ & 5 & $\begin{array}{l}23.39 .08 \\
23.42 .18 \\
\end{array}$ & $\begin{array}{l}41^{\circ} 26.08^{\prime} \mathrm{S} \\
42^{\circ} 52.10^{\prime} \mathrm{E}\end{array}$ & $\begin{array}{l}41^{\circ} 26.02^{\prime} \mathrm{S} \\
42^{\circ} 52.22^{\prime} \mathrm{E}\end{array}$ & $\begin{array}{l}50.1 \\
1.9 \\
\end{array}$ & 78 & $\begin{array}{l}1.2 / 1.3 \\
1.4 / 0.5 \\
\end{array}$ & $\begin{array}{l}92.3 \\
280 \\
\end{array}$ \\
\hline $\begin{array}{l}8 \\
\text { (PL110) }\end{array}$ & $02 / 12 / 09$ & 1 & $\begin{array}{l}00.04 .10 \\
00.06 .42\end{array}$ & $\begin{array}{l}41^{\circ} 25.62^{\prime} \mathrm{S} \\
42^{\circ} 53.24^{\prime} \mathrm{E}\end{array}$ & $\begin{array}{l}41^{\circ} 25.57^{\prime} \mathrm{S} \\
42^{\circ} 53.43^{\prime} \mathrm{E}\end{array}$ & $\begin{array}{l}200.4 \\
149.8\end{array}$ & 56 & $\begin{array}{l}1.0 / 0.7 \\
1.2 / 1.2\end{array}$ & $\begin{array}{l}142.9 \\
100.0\end{array}$ \\
\hline $\begin{array}{l}8 \\
\text { (PL110) }\end{array}$ & $02 / 12 / 09$ & 2 & $\begin{array}{l}00.06 .43 \\
00.11 .21\end{array}$ & $\begin{array}{l}41^{\circ} 25.57^{\prime} \mathrm{S} \\
42^{\circ} 53.43^{\prime} \mathrm{E}\end{array}$ & $\begin{array}{l}41^{\circ} 25.48^{\prime} \mathrm{S} \\
42^{\circ} 53.67^{\prime} \mathrm{E}\end{array}$ & $\begin{array}{l}149.8 \\
100.8\end{array}$ & 111 & $\begin{array}{l}1.2 / 1.2 \\
1.5 / 1.7\end{array}$ & $\begin{array}{l}100.0 \\
88.2\end{array}$ \\
\hline $\begin{array}{l}8 \\
\text { (PL110) }\end{array}$ & $02 / 12 / 09$ & 3 & $\begin{array}{l}00.11 .22 \\
00.16 .19\end{array}$ & $\begin{array}{l}41^{\circ} 25.48^{\prime} \mathrm{S} \\
42^{\circ} 53.67^{\prime} \mathrm{E}\end{array}$ & $\begin{array}{l}41^{\circ} 25.37^{\prime} \mathrm{S} \\
42^{\circ} 53.97^{\prime} \mathrm{E}\end{array}$ & $\begin{array}{l}100.8 \\
50.2\end{array}$ & 129 & $\begin{array}{l}1.4 / 1.5 \\
1.2 / 1.4\end{array}$ & $\begin{array}{l}93.3 \\
85.7\end{array}$ \\
\hline $\begin{array}{l}8 \\
\text { (PL110) }\end{array}$ & $02 / 12 / 09$ & 4 & $\begin{array}{l}00.16 .20 \\
00.18 .02\end{array}$ & $\begin{array}{l}41^{\circ} 25.37^{\prime} \mathrm{S} \\
42^{\circ} 53.97^{\prime} \mathrm{E}\end{array}$ & $\begin{array}{l}41^{\circ} 25.32^{\prime} \mathrm{S} \\
42^{\circ} 54.08^{\prime} \mathrm{E}\end{array}$ & $\begin{array}{l}50.4 \\
24.5\end{array}$ & 42 & $\begin{array}{l}1.0 / 1.2 \\
1.7 / 1.8\end{array}$ & $\begin{array}{l}83.3 \\
94.4\end{array}$ \\
\hline $\begin{array}{l}8 \\
\text { (PL110) }\end{array}$ & $02 / 12 / 09$ & 5 & $\begin{array}{l}00.18 .03 \\
00.19 .18\end{array}$ & $\begin{array}{l}41^{\circ} 25.32^{\prime} \mathrm{S} \\
42^{\circ} 54.08^{\prime} \mathrm{E}\end{array}$ & $\begin{array}{l}41^{\circ} 25.30^{\prime} \mathrm{S} \\
42^{\circ} 54.13^{\prime} \mathrm{E}\end{array}$ & $\begin{array}{l}24.4 \\
0.7\end{array}$ & 31 & $\begin{array}{l}1.6 / 1.6 \\
1.3 / 0.4\end{array}$ & $\begin{array}{l}100.0 \\
325.0\end{array}$ \\
\hline
\end{tabular}




\begin{tabular}{|c|c|c|c|c|c|c|c|c|c|}
\hline $\begin{array}{l}9 \\
\text { (PL146) }\end{array}$ & $07 / 12 / 09$ & 1 & $\begin{array}{l}21.54 .41 \\
22.00 .32\end{array}$ & $\begin{array}{l}38^{\circ} 29.64^{\prime} \mathrm{S} \\
46^{\circ} 44.33^{\prime} \mathrm{E}\end{array}$ & $\begin{array}{l}38^{\circ} 29.67^{\prime} \mathrm{S} \\
46^{\circ} 43.96^{\prime} \mathrm{E}\end{array}$ & $\begin{array}{l}200.7 \\
148.8\end{array}$ & 113 & $\begin{array}{l}0.5 / 0.3 \\
0.1 / 0.5\end{array}$ & $\begin{array}{l}166.7 \\
20.0\end{array}$ \\
\hline $\begin{array}{l}9 \\
\text { (PL146) }\end{array}$ & $07 / 12 / 09$ & 2 & $\begin{array}{l}22.00 .33 \\
22.07 .27\end{array}$ & $\begin{array}{l}38^{\circ} 29.67^{\prime} \mathrm{S} \\
46^{\circ} 43.96^{\prime} \mathrm{E}\end{array}$ & $\begin{array}{l}38^{\circ} 29.77^{\prime} \mathrm{S} \\
46^{\circ} 43.73^{\prime} \mathrm{E}\end{array}$ & $\begin{array}{l}148.7 \\
99.9\end{array}$ & 172 & $\begin{array}{l}0.1 / 0.3 \\
1.0 / 1.1\end{array}$ & $\begin{array}{l}33.3 \\
90.9\end{array}$ \\
\hline $\begin{array}{l}9 \\
\text { (PL146) }\end{array}$ & $07 / 12 / 09$ & 3 & $\begin{array}{l}22.07 .28 \\
22.11 .55\end{array}$ & $\begin{array}{l}38^{\circ} 29.77^{\prime} \mathrm{S} \\
46^{\circ} 43.73^{\prime} \mathrm{E}\end{array}$ & $\begin{array}{l}38^{\circ} 29.89^{\prime} \mathrm{S} \\
46^{\circ} 43.61^{\prime} \mathrm{E}\end{array}$ & $\begin{array}{l}99.9 \\
50.9\end{array}$ & 105 & $\begin{array}{l}1.4 / 1.2 \\
1.4 / 1.3\end{array}$ & $\begin{array}{l}116.7 \\
107.7\end{array}$ \\
\hline $\begin{array}{l}9 \\
\text { (PL146) }\end{array}$ & $07 / 12 / 09$ & 4 & $\begin{array}{l}22.11 .56 \\
22.13 .49 \\
\end{array}$ & $\begin{array}{l}38^{\circ} 29.89^{\prime} \mathrm{S} \\
46^{\circ} 43.61^{\prime} \mathrm{E}\end{array}$ & $\begin{array}{l}38^{\circ} 29.98^{\prime} \mathrm{S} \\
46^{\circ} 43.59^{\prime} \mathrm{E}\end{array}$ & $\begin{array}{l}50.8 \\
25.3 \\
\end{array}$ & 46 & $\begin{array}{l}1.4 / 1.2 \\
1.5 / 1.4\end{array}$ & $\begin{array}{l}116.7 \\
107.1 \\
\end{array}$ \\
\hline $\begin{array}{l}9 \\
\text { (PL146) }\end{array}$ & $07 / 12 / 09$ & 5 & $\begin{array}{l}22.13 .50 \\
22.15 .18\end{array}$ & $\begin{array}{l}38^{\circ} 29.98^{\prime} \mathrm{S} \\
46^{\circ} 43.59^{\prime} \mathrm{E}\end{array}$ & $\begin{array}{l}38^{\circ} 30.01^{\prime} \mathrm{S} \\
46^{\circ} 43.58^{\prime} \mathrm{E}\end{array}$ & $\begin{array}{l}25.4 \\
0.7\end{array}$ & 37 & $\begin{array}{l}1.1 / 1.2 \\
1.0 / 1.4\end{array}$ & $\begin{array}{l}91.7 \\
71.4\end{array}$ \\
\hline $\begin{array}{l}9 \\
\text { (PL147) }\end{array}$ & $07 / 12 / 09$ & 1 & $\begin{array}{l}22.49 .08 \\
22.55 .34 \\
\end{array}$ & $\begin{array}{l}38^{\circ} 30.31^{\prime} \mathrm{S} \\
46^{\circ} 43.8^{\prime} \mathrm{E}\end{array}$ & $\begin{array}{l}38^{\circ} 30.12^{\prime} \mathrm{S} \\
46^{\circ} 44.01^{\prime} \mathrm{E}\end{array}$ & $\begin{array}{l}250.6 \\
200.7 \\
\end{array}$ & 126 & $\begin{array}{l}0.7 / 0.3 \\
0.5 / 0.5 \\
\end{array}$ & $\begin{array}{l}233.3 \\
100.0 \\
\end{array}$ \\
\hline $\begin{array}{l}9 \\
\text { (PL147) }\end{array}$ & $07 / 12 / 09$ & 2 & $\begin{array}{l}22.55 .35 \\
23.03 .12 \\
\end{array}$ & $\begin{array}{l}38^{\circ} 30.12^{\prime} \mathrm{S} \\
46^{\circ} 44.01^{\prime} \mathrm{E}\end{array}$ & $\begin{array}{l}38^{\circ} 29.92^{\prime} \mathrm{S} \\
46^{\circ} 44.23^{\prime} \mathrm{E}\end{array}$ & $\begin{array}{l}200.5 \\
150.4\end{array}$ & 198 & $\begin{array}{l}1.2 / 1.0 \\
1.8 / 1.8\end{array}$ & $\begin{array}{l}120.0 \\
100.0\end{array}$ \\
\hline $\begin{array}{l}9 \\
\text { (PL147) }\end{array}$ & $07 / 12 / 09$ & 3 & $\begin{array}{l}23.03 .13 \\
23.08 .32\end{array}$ & $\begin{array}{l}38^{\circ} 29.92 ' \mathrm{~S} \\
46^{\circ} 44.23^{\prime} \mathrm{E}\end{array}$ & $\begin{array}{l}38^{\circ} 29.78^{\prime} \mathrm{S} \\
46^{\circ} 44.44^{\prime} \mathrm{E}\end{array}$ & $\begin{array}{l}150.8 \\
99.3\end{array}$ & 125 & $\begin{array}{l}1.2 / 1.4 \\
2.2 / 2.3\end{array}$ & $\begin{array}{l}85.7 \\
95.6\end{array}$ \\
\hline $\begin{array}{l}9 \\
\text { (PL147) }\end{array}$ & $07 / 12 / 09$ & 4 & $\begin{array}{l}23.08 .33 \\
23.12 .09\end{array}$ & $\begin{array}{l}38^{\circ} 29.78^{\prime} \mathrm{S} \\
46^{\circ} 44.44^{\prime} \mathrm{E}\end{array}$ & $\begin{array}{l}38^{\circ} 29.69^{\prime} \mathrm{S} \\
46^{\circ} 44.53^{\prime} \mathrm{E}\end{array}$ & $\begin{array}{l}99.0 \\
50.7\end{array}$ & 86 & $\begin{array}{l}1.7 / 2.0 \\
1.0 / 1.1\end{array}$ & $\begin{array}{l}85.0 \\
90.9\end{array}$ \\
\hline $\begin{array}{l}9 \\
\text { (PL147) }\end{array}$ & $07 / 12 / 09$ & 5 & $\begin{array}{l}23.12 .10 \\
23.15 .50 \\
\end{array}$ & $\begin{array}{l}38^{\circ} 29.69^{\prime} \mathrm{S} \\
46^{\circ} 44.53^{\prime} \mathrm{E} \\
\end{array}$ & $\begin{array}{l}38^{\circ} 29.58^{\prime} \mathrm{S} \\
46^{\circ} 44.66^{\prime} \mathrm{E}\end{array}$ & $\begin{array}{l}50.0 \\
1.7 \\
\end{array}$ & 87 & $\begin{array}{l}1.8 / 1.4 \\
0.6 / 1.2 \\
\end{array}$ & $\begin{array}{l}128.6 \\
50.0 \\
\end{array}$ \\
\hline $\begin{array}{l}9 \\
\text { (PL148) }\end{array}$ & $07 / 12 / 09$ & 1 & $\begin{array}{l}23.44 .11 \\
23.48 .29 \\
\end{array}$ & $\begin{array}{l}38^{\circ} 28.87^{\prime} \mathrm{S} \\
46^{\circ} 45.63^{\prime} \mathrm{E}\end{array}$ & $\begin{array}{l}38^{\circ} 28.79^{\prime} \mathrm{S} \\
46^{\circ} 45.79^{\prime} \mathrm{E}\end{array}$ & $\begin{array}{l}200.4 \\
150.1\end{array}$ & 65 & $\begin{array}{l}0.3 / 0.4 \\
0.2 / 0.6\end{array}$ & $\begin{array}{l}75.0 \\
33.3 \\
\end{array}$ \\
\hline $\begin{array}{l}9 \\
\text { (PL148) }\end{array}$ & $07 / 12 / 09$ & 2 & $\begin{array}{l}23.48 .30 \\
23.53 .22\end{array}$ & $\begin{array}{l}38^{\circ} 28.79^{\prime} \mathrm{S} \\
46^{\circ} 45.79^{\prime} \mathrm{E}\end{array}$ & $\begin{array}{l}38^{\circ} 28.72 ' \mathrm{~S} \\
46^{\circ} 46.01^{\prime} \mathrm{E}\end{array}$ & $\begin{array}{l}150.3 \\
101.5\end{array}$ & 82 & $\begin{array}{l}0.5 / 0.7 \\
0.5 / 0.8\end{array}$ & $\begin{array}{l}71.4 \\
62.5\end{array}$ \\
\hline $\begin{array}{l}9 \\
\text { (PL148) }\end{array}$ & $07 / 12 / 09$ & 3 & $\begin{array}{l}23.53 .23 \\
23.58 .03 \\
\end{array}$ & $\begin{array}{l}38^{\circ} 28.72^{\prime} \mathrm{S} \\
46^{\circ} 46.01^{\prime} \mathrm{E}\end{array}$ & $\begin{array}{l}38^{\circ} 28.67^{\prime} \mathrm{S} \\
46^{\circ} 46.22^{\prime} \mathrm{E}\end{array}$ & $\begin{array}{l}101.9 \\
50.1 \\
\end{array}$ & 84 & $\begin{array}{l}0.6 / 0.7 \\
0.8 / 1.2 \\
\end{array}$ & $\begin{array}{l}85.7 \\
66.7 \\
\end{array}$ \\
\hline $\begin{array}{l}9 \\
\text { (PL148) }\end{array}$ & $08 / 12 / 09$ & 4 & $\begin{array}{l}23.58 .04 \\
00.00 .17\end{array}$ & $\begin{array}{l}38^{\circ} 28.67^{\prime} \mathrm{S} \\
46^{\circ} 46.22^{\prime} \mathrm{E}\end{array}$ & $\begin{array}{l}38^{\circ} 28.65^{\prime} \mathrm{S} \\
46^{\circ} 46.30^{\prime} \mathrm{E}\end{array}$ & $\begin{array}{l}51.3 \\
25.4\end{array}$ & 47 & $\begin{array}{l}1.0 / 1.2 \\
1.0 / 1.1\end{array}$ & $\begin{array}{l}83.3 \\
90.9\end{array}$ \\
\hline $\begin{array}{l}9 \\
\text { (PL148) }\end{array}$ & $08 / 12 / 09$ & 5 & $\begin{array}{l}00.00 .18 \\
00.02 .05 \\
\end{array}$ & $\begin{array}{l}38^{\circ} 28.65^{\prime} \mathrm{S} \\
46^{\circ} 46.30^{\prime} \mathrm{E}\end{array}$ & $\begin{array}{l}38^{\circ} 28.62 ' \mathrm{~S} \\
46^{\circ} 46.39^{\prime} \mathrm{E}\end{array}$ & $\begin{array}{l}26.3 \\
0.2 \\
\end{array}$ & 38 & $\begin{array}{l}0.9 / 1.0 \\
1.8 / 1.8 \\
\end{array}$ & $\begin{array}{l}90.0 \\
100.0\end{array}$ \\
\hline $\begin{array}{l}9 \\
\text { (PL149) }\end{array}$ & $08 / 12 / 09$ & 1 & $\begin{array}{l}02.16 .06 \\
02.21 .35\end{array}$ & $\begin{array}{l}38^{\circ} 28.19^{\prime} \mathrm{S} \\
46^{\circ} 43.95^{\prime} \mathrm{E}\end{array}$ & $\begin{array}{l}38^{\circ} 28.04^{\prime} \mathrm{S} \\
46^{\circ} 43.76^{\prime} \mathrm{E}\end{array}$ & $\begin{array}{l}201.3 \\
149.5\end{array}$ & 96 & $\begin{array}{l}1.2 / 1.1 \\
1.4 / 1.6\end{array}$ & $\begin{array}{l}109.1 \\
87.5\end{array}$ \\
\hline $\begin{array}{l}9 \\
\text { (PL149) }\end{array}$ & $08 / 12 / 09$ & 2 & $\begin{array}{l}02.21 .36 \\
02.26 .36 \\
\end{array}$ & $\begin{array}{l}38^{\circ} 28.04^{\prime} \mathrm{S} \\
46^{\circ} 43.76^{\prime} \mathrm{E}\end{array}$ & $\begin{array}{l}38^{\circ} 27.87^{\prime} \mathrm{S} \\
46^{\circ} 43.51^{\prime} \mathrm{E}\end{array}$ & $\begin{array}{l}149.4 \\
100.1 \\
\end{array}$ & 128 & $\begin{array}{l}1.2 / 1.4 \\
2.0 / 2.1 \\
\end{array}$ & $\begin{array}{l}85.7 \\
95.2 \\
\end{array}$ \\
\hline $\begin{array}{l}9 \\
\text { (PL149) }\end{array}$ & $08 / 12 / 09$ & 3 & $\begin{array}{l}02.26 .37 \\
02.30 .55\end{array}$ & $\begin{array}{l}38^{\circ} 27.87^{\prime} \mathrm{S} \\
46^{\circ} 43.51^{\prime} \mathrm{E}\end{array}$ & $\begin{array}{l}38^{\circ} 27.76^{\prime} \mathrm{S} \\
46^{\circ} 43.44^{\prime} \mathrm{S}\end{array}$ & $\begin{array}{l}99.8 \\
51.4\end{array}$ & 111 & $\begin{array}{l}2.0 / 2.1 \\
1.0 / 1.4\end{array}$ & $\begin{array}{l}95.2 \\
71.4\end{array}$ \\
\hline $\begin{array}{l}9 \\
\text { (PL149) }\end{array}$ & $08 / 12 / 09$ & 4 & $\begin{array}{l}02.30 .56 \\
02.33 .02\end{array}$ & $\begin{array}{l}38^{\circ} 27.76^{\prime} \mathrm{S} \\
46^{\circ} 43.44^{\prime} \mathrm{S}\end{array}$ & $\begin{array}{l}38^{\circ} 27.70^{\prime} \mathrm{S} \\
46^{\circ} 43.43^{\prime} \mathrm{E}\end{array}$ & $\begin{array}{l}51.8 \\
25.5\end{array}$ & 53 & $\begin{array}{l}1.0 / 1.2 \\
1.2 / 1.5\end{array}$ & $\begin{array}{l}83.3 \\
80.0\end{array}$ \\
\hline $\begin{array}{l}9 \\
\text { (PL149) }\end{array}$ & $08 / 12 / 09$ & 5 & $\begin{array}{l}02.33 .03 \\
02.34 .42 \\
\end{array}$ & $\begin{array}{l}38^{\circ} 27.70^{\prime} \mathrm{S} \\
46^{\circ} 43.43^{\prime} \mathrm{E}\end{array}$ & $\begin{array}{l}38^{\circ} 27.64^{\prime} \mathrm{S} \\
46^{\circ} 43.43^{\prime} \mathrm{S}\end{array}$ & $\begin{array}{l}25.9 \\
0.2\end{array}$ & 43 & $\begin{array}{l}0.8 / 1.1 \\
1.7 / 1.4\end{array}$ & $\begin{array}{l}72.7 \\
121.4\end{array}$ \\
\hline $\begin{array}{l}9 \\
\text { (PL150) }\end{array}$ & $08 / 12 / 09$ & 1 & $\begin{array}{l}02.55 .05 \\
02.58 .31\end{array}$ & $\begin{array}{l}38^{\circ} 28.49^{\prime} \mathrm{S} \\
46^{\circ} 44.27^{\prime} \mathrm{E}\end{array}$ & $\begin{array}{l}38^{\circ} 29.07^{\prime} \mathrm{S} \\
46^{\circ} 44.51^{\prime} \mathrm{E}\end{array}$ & $\begin{array}{l}251.6 \\
200.4\end{array}$ & 53 & $\begin{array}{l}1.0 / 0.9 \\
0.1 / 0.1\end{array}$ & $\begin{array}{l}111.1 \\
100.0\end{array}$ \\
\hline $\begin{array}{l}9 \\
\text { (PL150) }\end{array}$ & $08 / 12 / 09$ & 2 & $\begin{array}{l}02.58 .32 \\
03.03 .33 \\
\end{array}$ & $\begin{array}{l}38^{\circ} 29.07^{\prime} \mathrm{S} \\
46^{\circ} 44.51^{\prime} \mathrm{E}\end{array}$ & $\begin{array}{l}38^{\circ} 29.47^{\prime} \mathrm{S} \\
46^{\circ} 44.80^{\prime} \mathrm{E}\end{array}$ & $\begin{array}{l}200.8 \\
149.2\end{array}$ & 116 & $\begin{array}{l}0.1 / 0.1 \\
1.8 / 2.0\end{array}$ & $\begin{array}{l}100.0 \\
90.0\end{array}$ \\
\hline $\begin{array}{l}9 \\
\text { (PL150) }\end{array}$ & $08 / 12 / 09$ & 3 & \begin{tabular}{|l|}
03.03 .34 \\
03.09 .01 \\
\end{tabular} & $\begin{array}{l}38^{\circ} 29.47^{\prime} \mathrm{S} \\
46^{\circ} 44.80^{\prime} \mathrm{E}\end{array}$ & $\begin{array}{l}38^{\circ} 29.38^{\prime} \mathrm{S} \\
46^{\circ} 44.98^{\prime} \mathrm{E}\end{array}$ & $\begin{array}{l}149.5 \\
98.9 \\
\end{array}$ & 137 & $\begin{array}{l}1.2 / 1.6 \\
2.3 / 2.4 \\
\end{array}$ & \begin{tabular}{|l}
75.0 \\
95.8 \\
\end{tabular} \\
\hline $\begin{array}{l}9 \\
\text { (PL150) }\end{array}$ & $08 / 12 / 09$ & 4 & $\begin{array}{l}03.09 .02 \\
03.12 .50\end{array}$ & $\begin{array}{l}38^{\circ} 29.38^{\prime} \mathrm{S} \\
46^{\circ} 44.98^{\prime} \mathrm{E}\end{array}$ & $\begin{array}{l}38^{\circ} 29.31^{\prime} \mathrm{S} \\
46^{\circ} 45.12^{\prime} \mathrm{E}\end{array}$ & $\begin{array}{l}98.8 \\
50.8\end{array}$ & 100 & $\begin{array}{l}1.8 / 2.1 \\
1.3 / 1.4\end{array}$ & $\begin{array}{l}85.7 \\
92.9 \\
\end{array}$ \\
\hline $\begin{array}{l}9 \\
\text { (PL150) }\end{array}$ & $08 / 12 / 09$ & 5 & $\begin{array}{l}03.12 .51 \\
03.15 .45\end{array}$ & $\begin{array}{l}38^{\circ} 29.31^{\prime} \mathrm{S} \\
46^{\circ} 45.12^{\prime} \mathrm{E}\end{array}$ & $\begin{array}{l}38^{\circ} 29.26^{\prime} \mathrm{S} \\
46^{\circ} 45.23^{\prime} \mathrm{E}\end{array}$ & $\begin{array}{l}50.6 \\
1.3\end{array}$ & 78 & $\begin{array}{l}1.6 / 1.4 \\
1.8 / 1.9\end{array}$ & $\begin{array}{l}114.3 \\
94.7\end{array}$ \\
\hline $\begin{array}{l}9 \\
\text { (PL151) }\end{array}$ & $08 / 12 / 09$ & 1 & $\begin{array}{l}03.51 .47 \\
03.54 .51 \\
\end{array}$ & $\begin{array}{l}38^{\circ} 28.67^{\prime} \mathrm{S} \\
46^{\circ} 46.52^{\prime} \mathrm{E}\end{array}$ & $\begin{array}{l}38^{\circ} 28.62 ' \mathrm{~S} \\
46^{\circ} 46.62^{\prime} \mathrm{E}\end{array}$ & $\begin{array}{l}199.8 \\
149.5 \\
\end{array}$ & 53 & $\begin{array}{l}1.2 / 1.1 \\
0.3 / 0.8 \\
\end{array}$ & $\begin{array}{l}109.1 \\
37.5 \\
\end{array}$ \\
\hline $\begin{array}{l}9 \\
\text { (PL151) }\end{array}$ & $08 / 12 / 09$ & 2 & $\begin{array}{l}03.54 .52 \\
03.59 .53 \\
\end{array}$ & $\begin{array}{l}38^{\circ} 28.62^{\prime} \mathrm{S} \\
46^{\circ} 46.62^{\prime} \mathrm{E}\end{array}$ & $\begin{array}{l}38^{\circ} 28.54^{\prime} \mathrm{S} \\
46^{\circ} 46.80^{\prime} \mathrm{E}\end{array}$ & $\begin{array}{l}149.4 \\
101.4 \\
\end{array}$ & 123 & $\begin{array}{l}0.6 / 1.0 \\
1.2 / 1.3 \\
\end{array}$ & $\begin{array}{l}60.0 \\
92.3 \\
\end{array}$ \\
\hline $\begin{array}{l}9 \\
\text { (PL151) }\end{array}$ & $08 / 12 / 09$ & 3 & $\begin{array}{l}03.59 .54 \\
04.04 .03 \\
\end{array}$ & $\begin{array}{l}38^{\circ} 28.54^{\prime} \mathrm{S} \\
46^{\circ} 46.80^{\prime} \mathrm{E}\end{array}$ & $\begin{array}{l}38^{\circ} 28.48^{\prime} \mathrm{S} \\
46^{\circ} 46.93^{\prime} \mathrm{E}\end{array}$ & $\begin{array}{l}101.5 \\
50.3 \\
\end{array}$ & 116 & $\begin{array}{l}1.3 / 1.3 \\
1.4 / 1.4 \\
\end{array}$ & $\begin{array}{l}100.0 \\
100.0 \\
\end{array}$ \\
\hline $\begin{array}{l}9 \\
\text { (PL151) }\end{array}$ & $08 / 12 / 09$ & 4 & $\begin{array}{l}04.04 .04 \\
04.06 .36\end{array}$ & $\begin{array}{l}38^{\circ} 28.48^{\prime} \mathrm{S} \\
46^{\circ} 46.93^{\prime} \mathrm{E}\end{array}$ & $\begin{array}{l}38^{\circ} 28.43^{\prime} \mathrm{S} \\
46^{\circ} 47.03^{\prime} \mathrm{E}\end{array}$ & $\begin{array}{l}50.0 \\
25.1\end{array}$ & 65 & $\begin{array}{l}1.7 / 1.5 \\
1.1 / 1.2\end{array}$ & $\begin{array}{l}113.3 \\
91.7\end{array}$ \\
\hline $\begin{array}{l}9 \\
\text { (PL151) }\end{array}$ & $08 / 12 / 09$ & 5 & $\begin{array}{l}04.06 .37 \\
04.09 .26 \\
\end{array}$ & $\begin{array}{l}38^{\circ} 28.43^{\prime} \mathrm{S} \\
46^{\circ} 47.03^{\prime} \mathrm{E}\end{array}$ & $\begin{array}{l}38^{\circ} 28.40^{\prime} \mathrm{S} \\
46^{\circ} 47.09^{\prime} \mathrm{E}\end{array}$ & $\begin{array}{l}25.7 \\
1.5\end{array}$ & 70 & $\begin{array}{l}0.8 / 1.1 \\
1.3 / 1.8\end{array}$ & $\begin{array}{l}72.7 \\
72.2\end{array}$ \\
\hline $\begin{array}{l}10 \\
\text { (PL177) }\end{array}$ & $12 / 12 / 09$ & 1 & $\begin{array}{l}18.11 .13 \\
18.15 .40\end{array}$ & $\begin{array}{l}31^{\circ} 36.87^{\prime} \mathrm{S} \\
42^{\circ} 48.64^{\prime} \mathrm{E}\end{array}$ & $\begin{array}{l}31^{\circ} 37.04^{\prime} \mathrm{S} \\
42^{\circ} 48.82^{\prime} \mathrm{E}\end{array}$ & $\begin{array}{l}199.7 \\
151.0\end{array}$ & 69 & $\begin{array}{l}1.5 / 1.3 \\
1.0 / 1.0\end{array}$ & $\begin{array}{l}115.4 \\
100.0\end{array}$ \\
\hline $\begin{array}{l}10 \\
\text { (PL177) }\end{array}$ & $12 / 12 / 09$ & 2 & $\begin{array}{l}18.15 .41 \\
18.21 .36\end{array}$ & $\begin{array}{l}31^{\circ} 37.04^{\prime} \mathrm{S} \\
42^{\circ} 48.82^{\prime} \mathrm{E}\end{array}$ & $\begin{array}{l}31^{\circ} 37.21^{\prime} \mathrm{S} \\
42^{\circ} 49.01^{\prime} \mathrm{E}\end{array}$ & $\begin{array}{l}151.0 \\
100.0\end{array}$ & 128 & $\begin{array}{l}1.2 / 1.0 \\
1.3 / 1.2\end{array}$ & $\begin{array}{l}120.0 \\
108.3\end{array}$ \\
\hline 10 & $12 / 12 / 09$ & 3 & 18.21 .37 & $31^{\circ} 37.21^{\prime} \mathrm{S}$ & $31^{\circ} 37.35^{\prime} \mathrm{S}$ & 99.9 & 99 & $1.4 / 1.2$ & 116.7 \\
\hline
\end{tabular}




\begin{tabular}{|c|c|c|c|c|c|c|c|c|c|}
\hline (PL177) & & & 18.26 .04 & $42^{\circ} 49.01^{\prime} \mathrm{E}$ & $42^{\circ} 49.15^{\prime} \mathrm{E}$ & 49.2 & & $1.4 / 1.6$ & 87.5 \\
\hline $\begin{array}{l}10 \\
\text { (PL177) }\end{array}$ & $12 / 12 / 09$ & 4 & $\begin{array}{l}18.26 .05 \\
18.27 .45\end{array}$ & $\begin{array}{l}31^{\circ} 37.35^{\prime} \mathrm{S} \\
42^{\circ} 49.15^{\prime} \mathrm{E}\end{array}$ & $\begin{array}{l}31^{\circ} 37.42 ' \mathrm{~S} \\
42^{\circ} 49.22^{\prime} \mathrm{E}\end{array}$ & $\begin{array}{l}49.3 \\
24.5 \\
\end{array}$ & 36 & $\begin{array}{l}1.0 / 1.2 \\
1.7 / 1.6\end{array}$ & $\begin{array}{l}83.3 \\
106.2\end{array}$ \\
\hline $\begin{array}{l}10 \\
\text { (PL177) }\end{array}$ & $12 / 12 / 09$ & 5 & $\begin{array}{l}18.27 .46 \\
18.30 .07 \\
\end{array}$ & $\begin{array}{l}31^{\circ} 37.42^{\prime} \mathrm{S} \\
42^{\circ} 49.22^{\prime} \mathrm{E}\end{array}$ & $\begin{array}{l}31^{\circ} 37.49^{\prime} \mathrm{S} \\
42^{\circ} 49.29^{\prime} \mathrm{E}\end{array}$ & $\begin{array}{l}24.4 \\
1.2 \\
\end{array}$ & 45 & $\begin{array}{l}1.2 / 1.3 \\
1.0 / 1.0 \\
\end{array}$ & $\begin{array}{l}92.3 \\
100.0 \\
\end{array}$ \\
\hline $\begin{array}{l}10 \\
\text { (PL178) }\end{array}$ & $12 / 12 / 09$ & 1 & $\begin{array}{l}18.47 .06 \\
18.50 .05 \\
\end{array}$ & $\begin{array}{l}1^{\circ} 38.03^{\prime} \mathrm{S} \\
42^{\circ} 49.90^{\prime} \mathrm{E}\end{array}$ & $\begin{array}{l}31^{\circ} 38.13 \text { 'S } \\
42^{\circ} 50.01^{\prime} \mathrm{E}\end{array}$ & $\begin{array}{l}250.8 \\
200.1 \\
\end{array}$ & 41 & $\begin{array}{l}1.1 / 1.0 \\
0.1 / 0.2 \\
\end{array}$ & $\begin{array}{l}110.0 \\
50.0\end{array}$ \\
\hline $\begin{array}{l}10 \\
\text { (PL178) }\end{array}$ & $12 / 12 / 09$ & 2 & $\begin{array}{l}18.50 .06 \\
18.55 .29 \\
\end{array}$ & $\begin{array}{l}31^{\circ} 38.13^{\prime} \mathrm{S} \\
42^{\circ} 50.01^{\prime} \mathrm{E}\end{array}$ & $\begin{array}{l}31^{\circ} 38.29^{\prime} \mathrm{S} \\
42^{\circ} 50.19^{\prime} \mathrm{E}\end{array}$ & $\begin{array}{l}199.6 \\
150.3 \\
\end{array}$ & 120 & $\begin{array}{l}0.1 / 0.5 \\
1.4 / 1.5 \\
\end{array}$ & $\begin{array}{l}20.0 \\
93.3 \\
\end{array}$ \\
\hline $\begin{array}{l}10 \\
\text { (PL178) }\end{array}$ & $12 / 12 / 09$ & 3 & $\begin{array}{l}18.55 .30 \\
19.00 .20\end{array}$ & $\begin{array}{l}31^{\circ} 38.29^{\prime} \mathrm{S} \\
42^{\circ} 50.19^{\prime} \mathrm{E}\end{array}$ & $\begin{array}{l}31^{\circ} 38.46^{\prime} \mathrm{S} \\
42^{\circ} 50.38^{\prime} \mathrm{E}\end{array}$ & $\begin{array}{l}150.3 \\
99.5\end{array}$ & 106 & $\begin{array}{l}1.3 / 1.4 \\
1.6 / 1.6\end{array}$ & $\begin{array}{l}92.9 \\
100.0\end{array}$ \\
\hline $\begin{array}{l}10 \\
\text { (PL178) }\end{array}$ & $12 / 12 / 09$ & 4 & $\begin{array}{l}19.00 .21 \\
19.04 .13 \\
\end{array}$ & $\begin{array}{l}31^{\circ} 38.46^{\prime} \mathrm{S} \\
42^{\circ} 50.38^{\prime} \mathrm{E} \\
\end{array}$ & $\begin{array}{l}31^{\circ} 38.60^{\prime} \mathrm{S} \\
42^{\circ} 50.53^{\prime} \mathrm{E}\end{array}$ & $\begin{array}{l}99.6 \\
49.7 \\
\end{array}$ & 82 & $\begin{array}{l}1.1 / 1.3 \\
1.2 / 1.2 \\
\end{array}$ & $\begin{array}{l}84.6 \\
100.0 \\
\end{array}$ \\
\hline $\begin{array}{l}10 \\
\text { (PL178) }\end{array}$ & $12 / 12 / 09$ & 5 & $\begin{array}{l}19.04 .14 \\
19.07 .06 \\
\end{array}$ & $\begin{array}{l}31^{\circ} 38.60^{\prime} \mathrm{S} \\
42^{\circ} 50.53^{\prime} \mathrm{E}\end{array}$ & $\begin{array}{l}31^{\circ} 38.71^{\prime} \mathrm{S} \\
42^{\circ} 50.64^{\prime} \mathrm{E}\end{array}$ & $\begin{array}{l}49.5 \\
0.5 \\
\end{array}$ & 60 & $\begin{array}{l}1.4 / 1.1 \\
1.2 / 1.0\end{array}$ & $\begin{array}{l}127.3 \\
120.0 \\
\end{array}$ \\
\hline $\begin{array}{l}10 \\
\text { (PL179) }\end{array}$ & $12 / 12 / 09$ & 1 & $\begin{array}{l}19.21 .14 \\
19.24 .40 \\
\end{array}$ & $\begin{array}{l}31^{\circ} 39.24^{\prime} \mathrm{S} \\
42^{\circ} 51.16^{\prime} \mathrm{E}\end{array}$ & $\begin{array}{l}31^{\circ} 39.37^{\prime} \mathrm{S} \\
42^{\circ} 51.30^{\prime} \mathrm{E}\end{array}$ & $\begin{array}{l}199.9 \\
149.1 \\
\end{array}$ & 53 & $\begin{array}{l}0.2 / 0.1 \\
1.1 / 1.2\end{array}$ & $\begin{array}{l}200.0 \\
91.7\end{array}$ \\
\hline $\begin{array}{l}10 \\
\text { (PL179) }\end{array}$ & $12 / 12 / 09$ & 2 & $\begin{array}{l}19.24 .41 \\
19.28 .26 \\
\end{array}$ & $\begin{array}{l}31^{\circ} 39.37^{\prime} \mathrm{S} \\
42^{\circ} 51.30^{\prime} \mathrm{E}\end{array}$ & $\begin{array}{l}31^{\circ} 39.47^{\prime} \mathrm{S} \\
42^{\circ} 51.40^{\prime} \mathrm{E}\end{array}$ & $\begin{array}{l}148.8 \\
100.5 \\
\end{array}$ & 72 & $\begin{array}{l}1.2 / 1.2 \\
0.9 / 1.1 \\
\end{array}$ & $\begin{array}{l}100.0 \\
81.8\end{array}$ \\
\hline $\begin{array}{l}10 \\
\text { (PL179) }\end{array}$ & $12 / 12 / 09$ & 3 & $\begin{array}{l}19.28 .27 \\
19.32 .44 \\
\end{array}$ & $\begin{array}{l}31^{\circ} 39.47^{\prime} \mathrm{S} \\
42^{\circ} 51.40^{\prime} \mathrm{E}\end{array}$ & $\begin{array}{l}31^{\circ} 39.64^{\prime} \mathrm{S} \\
42^{\circ} 51.59^{\prime} \mathrm{E}\end{array}$ & $\begin{array}{l}100.3 \\
51.2 \\
\end{array}$ & 85 & $\begin{array}{l}1.0 / 1.0 \\
1.0 / 0.9 \\
\end{array}$ & $\begin{array}{l}100.0 \\
111.1 \\
\end{array}$ \\
\hline $\begin{array}{l}10 \\
\text { (PL179) }\end{array}$ & $12 / 12 / 09$ & 4 & $\begin{array}{l}19.32 .45 \\
19.34 .47 \\
\end{array}$ & $\begin{array}{l}31^{\circ} 39.64^{\prime} \mathrm{S} \\
42^{\circ} 51.59^{\prime} \mathrm{E}\end{array}$ & $\begin{array}{l}31^{\circ} 39.71^{\prime} \mathrm{S} \\
42^{\circ} 51.67^{\prime} \mathrm{E}\end{array}$ & $\begin{array}{l}50.9 \\
24.7 \\
\end{array}$ & 45 & $\begin{array}{l}1.3 / 1.0 \\
1.6 / 1.6\end{array}$ & $\begin{array}{l}130.0 \\
100.0\end{array}$ \\
\hline $\begin{array}{l}10 \\
\text { (PL179) }\end{array}$ & $12 / 12 / 09$ & 5 & $\begin{array}{l}19.34 .48 \\
19.36 .24\end{array}$ & $\begin{array}{l}31^{\circ} 39.71^{\prime} \mathrm{S} \\
42^{\circ} 51.67^{\prime} \mathrm{E}\end{array}$ & $\begin{array}{l}31^{\circ} 39.74^{\prime} \mathrm{S} \\
42^{\circ} 51.71^{\prime} \mathrm{E}\end{array}$ & $\begin{array}{l}24.5 \\
0.1\end{array}$ & 40 & $\begin{array}{l}1.4 / 1.4 \\
0.8 / 0.3\end{array}$ & $\begin{array}{l}100.0 \\
266.7\end{array}$ \\
\hline $\begin{array}{l}10 \\
\text { (PL180) }\end{array}$ & $13 / 12 / 09$ & 1 & $\begin{array}{l}07.32 .40 \\
07.35 .27 \\
\end{array}$ & $\begin{array}{l}31^{\circ} 42.38^{\prime} \mathrm{S} \\
42^{\circ} 50.12^{\prime} \mathrm{E}\end{array}$ & $\begin{array}{l}31^{\circ} 42.14^{\prime} \mathrm{S} \\
42^{\circ} 49.83^{\prime} \mathrm{E}\end{array}$ & $\begin{array}{l}200.3 \\
150.2 \\
\end{array}$ & 48 & $\begin{array}{l}1.0 / 0.4 \\
0.8 / 1.0\end{array}$ & $\begin{array}{l}250.0 \\
80.0\end{array}$ \\
\hline $\begin{array}{l}10 \\
\text { (PL180) }\end{array}$ & $13 / 12 / 09$ & 2 & $\begin{array}{l}07.35 .28 \\
07.40 .01 \\
\end{array}$ & $\begin{array}{l}31^{\circ} 42.14^{\prime} \mathrm{S} \\
42^{\circ} 49.83^{\prime} \mathrm{E}\end{array}$ & $\begin{array}{l}31^{\circ} 41.53 \text { 'S } \\
42^{\circ} 49.13^{\prime} \mathrm{E}\end{array}$ & $\begin{array}{l}150.2 \\
100.2 \\
\end{array}$ & 94 & $\begin{array}{l}0.6 / 0.8 \\
1.5 / 1.2 \\
\end{array}$ & $\begin{array}{l}75.0 \\
125.0\end{array}$ \\
\hline $\begin{array}{l}10 \\
\text { (PL180) }\end{array}$ & $13 / 12 / 09$ & 3 & $\begin{array}{l}07.40 .02 \\
07.44 .07 \\
\end{array}$ & $\begin{array}{l}31^{\circ} 41.53^{\prime} \mathrm{S} \\
42^{\circ} 49.13^{\prime} \mathrm{E} \\
\end{array}$ & $\begin{array}{l}31^{\circ} 41.04^{\prime} \mathrm{S} \\
42^{\circ} 48.57^{\prime} \mathrm{E}\end{array}$ & $\begin{array}{l}99.9 \\
49.6 \\
\end{array}$ & 84 & $\begin{array}{l}1.6 / 1.3 \\
1.9 / 1.7 \\
\end{array}$ & $\begin{array}{l}123.1 \\
111.8 \\
\end{array}$ \\
\hline $\begin{array}{l}10 \\
\text { (PL180) }\end{array}$ & $13 / 12 / 09$ & 4 & $\begin{array}{l}07.44 .08 \\
07.45 .59\end{array}$ & $\begin{array}{l}31^{\circ} 41.04^{\prime} \mathrm{S} \\
42^{\circ} 48.57^{\prime} \mathrm{E}\end{array}$ & $\begin{array}{l}31^{\circ} 40.80^{\prime} \mathrm{S} \\
42^{\circ} 48.29^{\prime} \mathrm{E}\end{array}$ & $\begin{array}{l}49.1 \\
24.9 \\
\end{array}$ & 38 & $\begin{array}{l}1.8 / 1.8 \\
0.8 / 1.2\end{array}$ & $\begin{array}{l}100.0 \\
66.7\end{array}$ \\
\hline $\begin{array}{l}10 \\
\text { (PL180) }\end{array}$ & $13 / 12 / 09$ & 5 & $\begin{array}{l}07.46 .00 \\
07.47 .28 \\
\end{array}$ & $\begin{array}{l}31^{\circ} 40.80^{\prime} \mathrm{S} \\
42^{\circ} 48.29^{\prime} \mathrm{E}\end{array}$ & $\begin{array}{l}31^{\circ} 40.67^{\prime} \mathrm{S} \\
42^{\circ} 48.15^{\prime} \mathrm{E}\end{array}$ & $\begin{array}{l}25.1 \\
0.2 \\
\end{array}$ & 31 & $\begin{array}{l}0.7 / 0.9 \\
1.5 / 1.5 \\
\end{array}$ & $\begin{array}{l}77.8 \\
100.0\end{array}$ \\
\hline $\begin{array}{l}10 \\
\text { (PL181) }\end{array}$ & $13 / 12 / 09$ & 1 & $\begin{array}{l}08.10 .29 \\
08.14 .07 \\
\end{array}$ & $\begin{array}{l}31^{\circ} 37.86^{\prime} \mathrm{S} \\
42^{\circ} 44.90^{\prime} \mathrm{E}\end{array}$ & $\begin{array}{l}31^{\circ} 37.35^{\prime} \mathrm{S} \\
42^{\circ} 44.34^{\prime} \mathrm{E}\end{array}$ & $\begin{array}{l}250.2 \\
200.6 \\
\end{array}$ & 57 & $\begin{array}{l}0.3 / 5.0 \\
1.3 / 0.8 \\
\end{array}$ & $\begin{array}{l}6.0 \\
162.5 \\
\end{array}$ \\
\hline $\begin{array}{l}10 \\
\text { (PL181) }\end{array}$ & $13 / 12 / 09$ & 2 & $\begin{array}{l}08.14 .08 \\
08.21 .24 \\
\end{array}$ & $\begin{array}{l}31^{\circ} 37.35^{\prime} \mathrm{S} \\
42^{\circ} 44.34^{\prime} \mathrm{E} \\
\end{array}$ & $\begin{array}{l}31^{\circ} 36.48^{\prime} \mathrm{S} \\
42^{\circ} 43.36^{\prime} \mathrm{E}\end{array}$ & $\begin{array}{l}200.3 \\
150.4 \\
\end{array}$ & 152 & $\begin{array}{l}1.4 / 0.9 \\
1.3 / 1.2 \\
\end{array}$ & $\begin{array}{l}155.6 \\
108.3 \\
\end{array}$ \\
\hline $\begin{array}{l}10 \\
\text { (PL181) }\end{array}$ & $13 / 12 / 09$ & 3 & $\begin{array}{l}08.21 .25 \\
08.27 .45 \\
\end{array}$ & $\begin{array}{l}31^{\circ} 36.48^{\prime} \mathrm{S} \\
42^{\circ} 43.36^{\prime} \mathrm{E}\end{array}$ & $\begin{array}{l}31^{\circ} 36.25^{\prime} \mathrm{S} \\
42^{\circ} 43.48^{\prime} \mathrm{E}\end{array}$ & $\begin{array}{l}150.3 \\
100.6\end{array}$ & 137 & $\begin{array}{l}1.4 / 1.2 \\
1.4 / 1.2\end{array}$ & $\begin{array}{l}116.7 \\
116.7\end{array}$ \\
\hline $\begin{array}{l}10 \\
\text { (PL181) }\end{array}$ & $13 / 12 / 09$ & 4 & $\begin{array}{l}08.27 .46 \\
08.33 .42 \\
\end{array}$ & $\begin{array}{l}31^{\circ} 36.25^{\prime} \mathrm{S} \\
42^{\circ} 43.48^{\prime} \mathrm{E}\end{array}$ & $\begin{array}{l}31^{\circ} 36.24^{\prime} \mathrm{S} \\
42^{\circ} 43.74^{\prime} \mathrm{E}\end{array}$ & $\begin{array}{l}100.5 \\
50.7\end{array}$ & 125 & $\begin{array}{l}1.4 / 1.2 \\
1.4 / 1.0\end{array}$ & $\begin{array}{l}116.7 \\
140.0\end{array}$ \\
\hline $\begin{array}{l}10 \\
\text { (PL181) }\end{array}$ & $13 / 12 / 09$ & 5 & $\begin{array}{l}08.33 .43 \\
08.38 .10 \\
\end{array}$ & $\begin{array}{l}31^{\circ} 36.24^{\prime} \mathrm{S} \\
42^{\circ} 43.74^{\prime} \mathrm{E}\end{array}$ & $\begin{array}{l}31^{\circ} 36.24^{\prime} \mathrm{S} \\
42^{\circ} 43.94^{\prime} \mathrm{E}\end{array}$ & $\begin{array}{l}50.5 \\
0.9 \\
\end{array}$ & 98 & $\begin{array}{l}1.4 / 1.1 \\
1.0 / 1.0\end{array}$ & $\begin{array}{l}127.3 \\
100.0 \\
\end{array}$ \\
\hline
\end{tabular}


Table 6. Aakra trawl deployments

\begin{tabular}{|c|c|c|c|c|c|c|}
\hline $\begin{array}{l}\text { Nansen Trawl } \\
\text { Number } \\
\end{array}$ & Station & Date & Start position & End position & $\begin{array}{l}\text { Maximum } \\
\text { depth }\end{array}$ & $\begin{array}{l}\text { Day / Night / } \\
\text { Dawn }\end{array}$ \\
\hline 1 & 2 & $14 / 11 / 09$ & $\begin{array}{l}26^{\circ} 55.85^{\prime} \mathrm{S} \\
56^{\circ} 11.34^{\prime} \mathrm{E}\end{array}$ & $\begin{array}{l}26^{\circ} 56.32^{\prime} \mathrm{S} \\
56^{\circ} 13.80^{\prime} \mathrm{E}\end{array}$ & 600 & $\mathrm{D}$ \\
\hline 2 & 2 & $14 / 11 / 09$ & $\begin{array}{l}26^{\circ} 56.45^{\prime} \mathrm{S} \\
56^{\circ} 14.22^{\prime} \mathrm{E} \\
\end{array}$ & $\begin{array}{l}26^{\circ} 56.81^{\prime} \mathrm{S} \\
56^{\circ} 16.74^{\prime} \mathrm{E} \\
\end{array}$ & 300 & $\mathrm{D}$ \\
\hline 3 & 2 & $14 / 11 / 09$ & $\begin{array}{l}26^{\circ} 56.81^{\prime} \mathrm{S} \\
56^{\circ} 16.92^{\prime} \mathrm{E}\end{array}$ & $\begin{array}{l}26^{\circ} 57.17^{\prime} \mathrm{S} \\
56^{\circ} 19.44^{\prime} \mathrm{E} \\
\end{array}$ & 50 & $\mathrm{D}$ \\
\hline 4 & 2 & $15 / 11 / 09$ & $\begin{array}{l}26^{\circ} 59.15^{\prime} \mathrm{S} \\
56^{\circ} 14.58^{\prime} \mathrm{E}\end{array}$ & $\begin{array}{l}26^{\circ} 55.79^{\prime} \mathrm{S} \\
56^{\circ} 10.80^{\prime} \mathrm{E}\end{array}$ & 800 & $\mathrm{D}$ \\
\hline 5 & 4 & $17 / 11 / 09$ & $\begin{array}{l}32^{\circ} 43.49^{\prime} \mathrm{S} \\
57^{\circ} 17.82^{\prime} \mathrm{E}\end{array}$ & $\begin{array}{l}32^{\circ} 42.89^{\prime} \mathrm{S} \\
57^{\circ} 14.46^{\prime} \mathrm{E}\end{array}$ & 700 & $\mathrm{D}$ \\
\hline 6 & 4 & $17 / 11 / 09$ & $\begin{array}{l}32^{\circ} 43.49^{\prime} \mathrm{S} \\
57^{\circ} 17.82^{\prime} \mathrm{E}\end{array}$ & $\begin{array}{l}32^{\circ} 43.31^{\prime} \mathrm{S} \\
57^{\circ} 13.98^{\prime} \mathrm{E} \\
\end{array}$ & 400 & $\mathrm{D}$ \\
\hline 7 & 4 & $18 / 11 / 09$ & $\begin{array}{l}32^{\circ} 43.61^{\prime} \mathrm{S} \\
57^{\circ} 17.82^{\prime} \mathrm{E}\end{array}$ & $\begin{array}{l}32^{\circ} 43.55^{\prime} \mathrm{S} \\
57^{\circ} 15.72^{\prime} \mathrm{E}\end{array}$ & 700 & $\mathrm{~N}$ \\
\hline 8 & 4 & $18 / 11 / 09$ & $\begin{array}{l}32^{\circ} 43.31^{\prime} \mathrm{S} \\
57^{\circ} 16.44^{\prime} \mathrm{E}\end{array}$ & $\begin{array}{l}32^{\circ} 43.55^{\prime} \mathrm{S} \\
57^{\circ} 19.44^{\prime} \mathrm{E}\end{array}$ & 400 & $\mathrm{~N}$ \\
\hline 9 & 4 & $19 / 11 / 09$ & $\begin{array}{l}32^{\circ} 44.21^{\prime} \mathrm{S} \\
57^{\circ} 17.24^{\prime} \mathrm{E}\end{array}$ & $\begin{array}{l}32^{\circ} 41.57^{\prime} \mathrm{S} \\
57^{\circ} 17.82^{\prime} \mathrm{E}\end{array}$ & 740 & Dw \\
\hline 10 & 5 & $22 / 11 / 09$ & $\begin{array}{l}36^{\circ} 51.35^{\prime} \mathrm{S} \\
52^{\circ} 03.34^{\prime} \mathrm{E}\end{array}$ & $\begin{array}{l}36^{\circ} 49.13^{\prime} \mathrm{S} \\
52^{\circ} 03.72^{\prime} \mathrm{E}\end{array}$ & 750 & $\mathrm{D}$ \\
\hline 11 & 5 & $22 / 11 / 09$ & $\begin{array}{l}36^{\circ} 49.61^{\prime} \mathrm{S} \\
52^{\circ} 03.66^{\prime} \mathrm{E} \\
\end{array}$ & $\begin{array}{l}36^{\circ} 52.07^{\prime} \mathrm{S} \\
52^{\circ} 03.18^{\prime} \mathrm{E}\end{array}$ & 400 & $\mathrm{D}$ \\
\hline 12 & 5 & $23 / 11 / 09$ & $\begin{array}{l}36^{\circ} 50.51^{\prime} \mathrm{S} \\
52^{\circ} 03.36^{\prime} \mathrm{E} \\
\end{array}$ & $\begin{array}{l}36^{\circ} 48.29^{\prime} \mathrm{S} \\
53^{\circ} 03.72^{\prime} \mathrm{E} \\
\end{array}$ & 720 & $\mathrm{~N}$ \\
\hline 13 & 5 & $23 / 11 / 09$ & $\begin{array}{l}36^{\circ} 48.95^{\prime} \mathrm{S} \\
52^{\circ} 04.50^{\prime} \mathrm{E}\end{array}$ & $\begin{array}{l}36^{\circ} 47.21^{\prime} \mathrm{S} \\
52^{\circ} 07.08^{\prime} \mathrm{E}\end{array}$ & 400 & $\mathrm{~N}$ \\
\hline 14 & 5 & $23 / 11 / 09$ & $\begin{array}{l}36^{\circ} 47.27^{\prime} \mathrm{S} \\
52^{\circ} 07.26^{\prime} \mathrm{E}\end{array}$ & $\begin{array}{l}36^{\circ} 47.27^{\prime} \mathrm{S} \\
52^{\circ} 07.26^{\prime} \mathrm{E}\end{array}$ & 500 & $\mathrm{~N}$ \\
\hline 15 & 5 & $24 / 11 / 09$ & $\begin{array}{l}36^{\circ} 51.65^{\prime} \mathrm{S} \\
52^{\circ} 03.06^{\prime} \mathrm{E}\end{array}$ & $\begin{array}{l}36^{\circ} 48.41^{\prime} \mathrm{S} \\
52^{\circ} 03.96^{\prime} \mathrm{E}\end{array}$ & 750 & Dw \\
\hline 16 & 6 & $25 / 11 / 09$ & $\begin{array}{l}37^{\circ} 57.29^{\prime} \mathrm{S} \\
50^{\circ} 22.61^{\prime} \mathrm{E}\end{array}$ & $\begin{array}{l}37^{\circ} 57.05^{\prime} \mathrm{S} \\
50^{\circ} 25.85^{\prime} \mathrm{E}\end{array}$ & 700 & $\mathrm{~N}$ \\
\hline 17 & 6 & $25 / 11 / 09$ & $\begin{array}{l}37^{\circ} 57.17^{\prime} \mathrm{S} \\
50^{\circ} 25.25^{\prime} \mathrm{E}\end{array}$ & $\begin{array}{l}37^{\circ} 57.29^{\prime} \mathrm{S} \\
50^{\circ} 22.37^{\prime} \mathrm{E}\end{array}$ & 400 & $\mathrm{~N}$ \\
\hline 18 & 6 & $26 / 11 / 09$ & $\begin{array}{l}37^{\circ} 57.41^{\prime} \mathrm{S} \\
50^{\circ} 24.53^{\prime} \mathrm{E} \\
\end{array}$ & $\begin{array}{l}37^{\circ} 57.47^{\prime} \mathrm{S} \\
50^{\circ} 26.39^{\prime} \mathrm{E} \\
\end{array}$ & 930 & $\mathrm{~N}$ \\
\hline 19 & 6 & $27 / 11 / 09$ & $\begin{array}{l}37^{\circ} 57.35^{\prime} \mathrm{S} \\
50^{\circ} 24.17^{\prime} \mathrm{E}\end{array}$ & $\begin{array}{l}37^{\circ} 57.53^{\prime} \mathrm{S} \\
50^{\circ} 25.55^{\prime} \mathrm{E}\end{array}$ & 700 & $\mathrm{D}$ \\
\hline 20 & 6 & $27 / 11 / 09$ & $\begin{array}{l}37^{\circ} 57.47^{\prime} \mathrm{S} \\
50^{\circ} 25.37^{\prime} \mathrm{E}\end{array}$ & $\begin{array}{l}37^{\circ} 57.47^{\prime} \mathrm{S} \\
50^{\circ} 24.29^{\prime} \mathrm{E}\end{array}$ & 420 & $\mathrm{D}$ \\
\hline 21 & 7 & $29 / 11 / 09$ & $\begin{array}{l}41^{\circ} 28.79^{\prime} \mathrm{S} \\
49^{\circ} 32.03^{\prime} \mathrm{E} \\
\end{array}$ & $\begin{array}{l}41^{\circ} 31.07^{\prime} \mathrm{S} \\
49^{\circ} 29.57^{\prime} \mathrm{E}\end{array}$ & 700 & $\mathrm{~N}$ \\
\hline 22 & 7 & $29 / 11 / 09$ & $\begin{array}{l}41^{\circ} 30.59^{\prime} \mathrm{S} \\
49^{\circ} 30.23^{\prime} \mathrm{E}\end{array}$ & $\begin{array}{l}41^{\circ} 28.49^{\prime} \mathrm{S} \\
49^{\circ} 32.51^{\prime} \mathrm{E}\end{array}$ & 400 & $\mathrm{~N}$ \\
\hline 23 & 7 & $30 / 11 / 09$ & $\begin{array}{l}41^{\circ} 34.25^{\prime} \mathrm{S} \\
49^{\circ} 27.00^{\prime} \mathrm{E} \\
\end{array}$ & $\begin{array}{l}41^{\circ} 32.99^{\prime} \mathrm{S} \\
49^{\circ} 28.25^{\prime} \mathrm{E} \\
\end{array}$ & 700 & $\mathrm{D}$ \\
\hline 24 & 7 & $30 / 11 / 09$ & $\begin{array}{l}41^{\circ} 33.41^{\prime} \mathrm{S} \\
49^{\circ} 28.55^{\prime} \mathrm{E} \\
\end{array}$ & $\begin{array}{l}41^{\circ} 34.07^{\prime} \mathrm{S} \\
49^{\circ} 27.35^{\prime} \mathrm{E}\end{array}$ & 400 & $\mathrm{D}$ \\
\hline 25 & 8 & $02 / 12 / 09$ & $\begin{array}{l}41^{\circ} 25.61^{\prime} \mathrm{S} \\
42^{\circ} 55.67^{\prime} \mathrm{E}\end{array}$ & $\begin{array}{l}41^{\circ} 24.89^{\prime} \mathrm{S} \\
42^{\circ} 57.17^{\prime} \mathrm{E}\end{array}$ & 900 & $\mathrm{D}$ \\
\hline 26 & 8 & $02 / 12 / 09$ & $\begin{array}{l}41^{\circ} 24.65^{\prime} \mathrm{S} \\
42^{\circ} 56.51^{\prime} \mathrm{E} \\
\end{array}$ & $\begin{array}{l}41^{\circ} 25.07^{\prime} \mathrm{S} \\
42^{\circ} 54.77^{\prime} \mathrm{E} \\
\end{array}$ & 600 & $\mathrm{D}$ \\
\hline 27 & 8 & $02 / 12 / 09$ & $\begin{array}{l}41^{\circ} 25.55^{\prime} \mathrm{S} \\
42^{\circ} 55.79^{\prime} \mathrm{E}\end{array}$ & $\begin{array}{l}41^{\circ} 26.15^{\prime} \mathrm{S} \\
42^{\circ} 52.79^{\prime} \mathrm{E}\end{array}$ & 900 & $\mathrm{~N}$ \\
\hline 28 & 8 & $02 / 12 / 09$ & $\begin{array}{l}41^{\circ} 25.13^{\prime} \mathrm{S} \\
42^{\circ} 54.17^{\prime} \mathrm{E} \\
\end{array}$ & $\begin{array}{l}41^{\circ} 23.99^{\prime} \mathrm{S} \\
42^{\circ} 56.63^{\prime} \mathrm{E} \\
\end{array}$ & 643 & $\mathrm{~N}$ \\
\hline 29 & 8 & $03 / 12 / 09$ & $\begin{array}{l}41^{\circ} 24.71^{\prime} \mathrm{S} \\
42^{\circ} 52.19^{\prime} \mathrm{E} \\
\end{array}$ & $\begin{array}{l}41^{\circ} 24.11 ' \mathrm{~S} \\
42^{\circ} 54.29^{\prime} \mathrm{E} \\
\end{array}$ & 270 & Dw \\
\hline 30 & 9 & $07 / 12 / 09$ & $\begin{array}{l}38^{\circ} 30.23^{\prime} \mathrm{S} \\
46^{\circ} 45.53^{\prime} \mathrm{E}\end{array}$ & $\begin{array}{l}38^{\circ} 31.01 ' \mathrm{~S} \\
46^{\circ} 41.93{ }^{\prime} \mathrm{E}\end{array}$ & 860 & $\mathrm{~N}$ \\
\hline
\end{tabular}




\begin{tabular}{|c|c|c|c|c|c|c|}
\hline 31 & 9 & $07 / 12 / 09$ & $\begin{array}{l}38^{\circ} 28.67^{\prime} \mathrm{S} \\
46^{\circ} 46.79^{\prime} \mathrm{E}\end{array}$ & $\begin{array}{l}38^{\circ} 29.69^{\prime} \mathrm{S} \\
46^{\circ} 43.79^{\prime} \mathrm{E}\end{array}$ & 480 & $\mathrm{~N}$ \\
\hline 32 & 9 & $08 / 12 / 09$ & $\begin{array}{l}38^{\circ} 28.49^{\prime} \mathrm{S} \\
46^{\circ} 46.25^{\prime} \mathrm{E}\end{array}$ & $\begin{array}{l}38^{\circ} 28.37^{\prime} \mathrm{S} \\
46^{\circ} 44.21^{\prime} \mathrm{E}\end{array}$ & 320 & Dw \\
\hline 33 & 9 & $08 / 12 / 09$ & $\begin{array}{l}38^{\circ} 30.29^{\prime} \mathrm{S} \\
46^{\circ} 45.59^{\prime} \mathrm{E}\end{array}$ & $\begin{array}{l}38^{\circ} 30.89^{\prime} \mathrm{S} \\
46^{\circ} 42.65^{\prime} \mathrm{E}\end{array}$ & 850 & $\mathrm{D}$ \\
\hline 34 & 9 & $08 / 12 / 09$ & $\begin{array}{l}38^{\circ} 29.57^{\prime} \mathrm{S} \\
46^{\circ} 44.57^{\prime} \mathrm{E}\end{array}$ & $\begin{array}{l}38^{\circ} 28.43^{\prime} \mathrm{S} \\
46^{\circ} 47.45^{\prime} \mathrm{E}\end{array}$ & 430 & $\mathrm{D}$ \\
\hline 35 & 9 & $08 / 12 / 09$ & $\begin{array}{l}38^{\circ} 27.89^{\prime} \mathrm{S} \\
46^{\circ} 44.93^{\prime} \mathrm{E}\end{array}$ & $\begin{array}{l}38^{\circ} 28.49^{\prime} \mathrm{S} \\
46^{\circ} 42.05^{\prime} \mathrm{E}\end{array}$ & 560 & $\mathrm{D}$ \\
\hline 36 & 10 & $12 / 12 / 09$ & $\begin{array}{l}31^{\circ} 38.45^{\prime} \mathrm{S} \\
42^{\circ} 49.97^{\prime} \mathrm{E}\end{array}$ & $\begin{array}{l}31^{\circ} 37.43^{\prime} \mathrm{S} \\
42^{\circ} 50.39^{\prime} \mathrm{E}\end{array}$ & 700 & $\mathrm{~N}$ \\
\hline 37 & 10 & $12 / 12 / 09$ & $\begin{array}{l}31^{\circ} 35.33^{\prime} \mathrm{S} \\
42^{\circ} 51.59^{\prime} \mathrm{E}\end{array}$ & $\begin{array}{l}31^{\circ} 34.85^{\prime} \mathrm{S} \\
42^{\circ} 53.09^{\prime} \mathrm{E}\end{array}$ & 1100 & $\mathrm{~N}$ \\
\hline 38 & 10 & $13 / 12 / 09$ & $\begin{array}{l}31^{\circ} 35.75^{\prime} \mathrm{S} \\
42^{\circ} 52.79^{\prime} \mathrm{E}\end{array}$ & $\begin{array}{l}31^{\circ} 36.29^{\prime} \mathrm{S} \\
42^{\circ} 51.53^{\prime} \mathrm{E}\end{array}$ & 300 & $\mathrm{~N}$ \\
\hline 39 & 10 & $14 / 12 / 09$ & $\begin{array}{l}31^{\circ} 38.87^{\prime} \mathrm{S} \\
42^{\circ} 48.77^{\prime} \mathrm{E}\end{array}$ & $\begin{array}{l}31^{\circ} 39.77^{\prime} \mathrm{S} \\
42^{\circ} 48.17^{\prime} \mathrm{E}\end{array}$ & 1100 & $\mathrm{D}$ \\
\hline 40 & 10 & $14 / 12 / 09$ & $\begin{array}{l}31^{\circ} 38.69^{\prime} \mathrm{S} \\
42^{\circ} 48.77^{\prime} \mathrm{E}\end{array}$ & $\begin{array}{l}31^{\circ} 37.61^{\prime} \mathrm{S} \\
42^{\circ} 49.67^{\prime} \mathrm{E}\end{array}$ & 700 & D \\
\hline
\end{tabular}


Figure 1

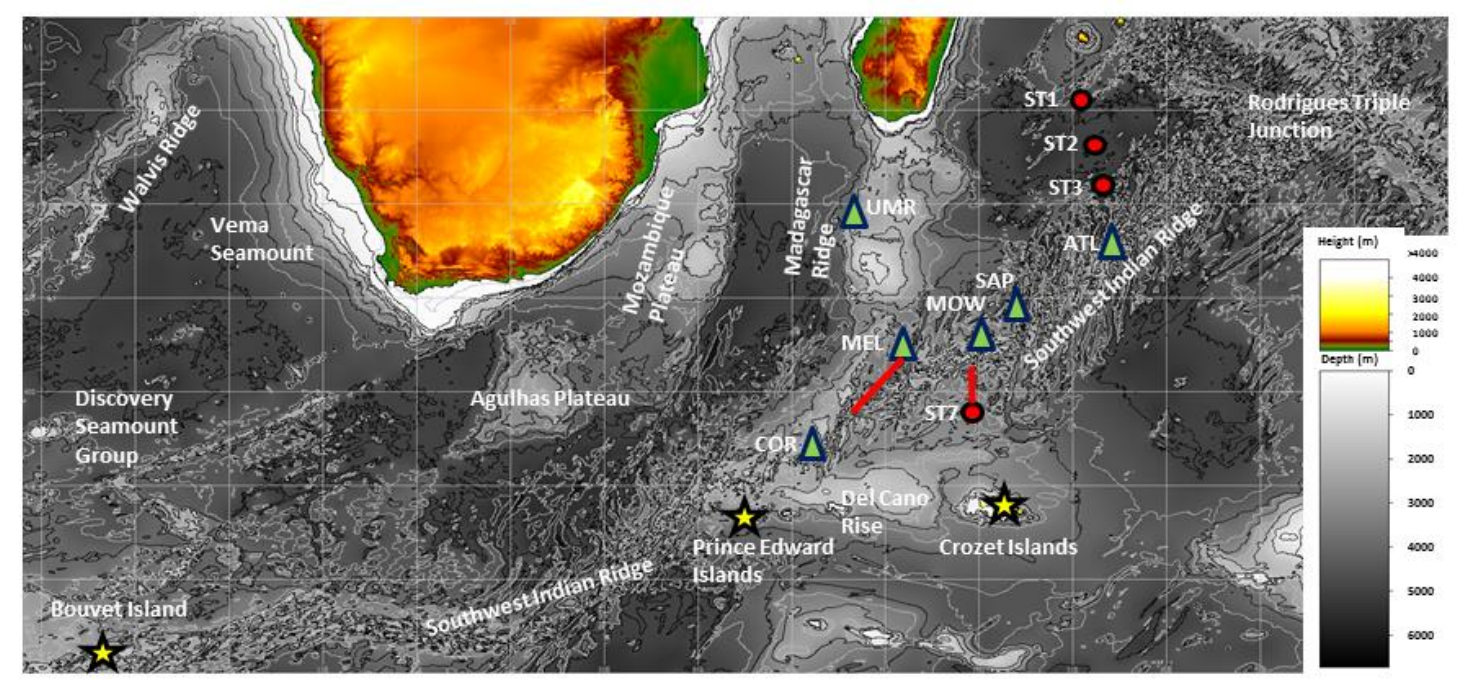


Figure 2

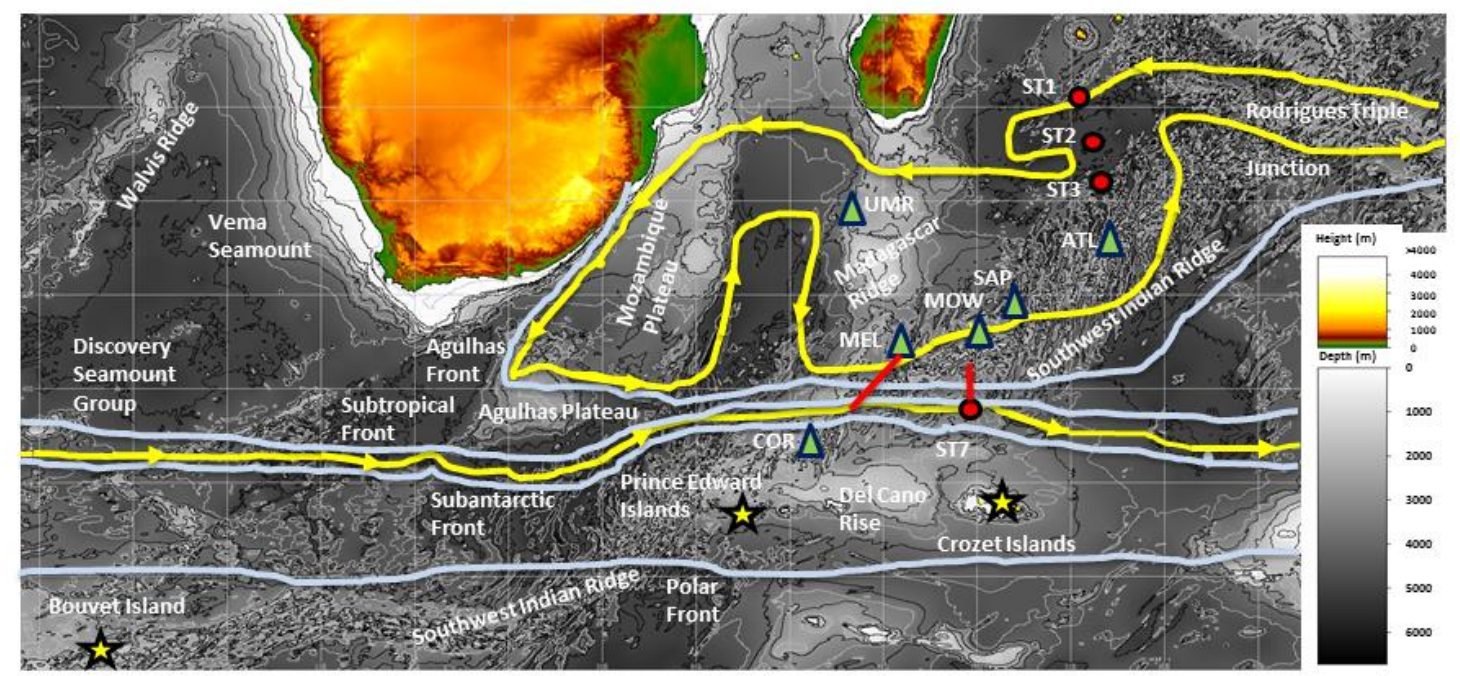


Figure 3

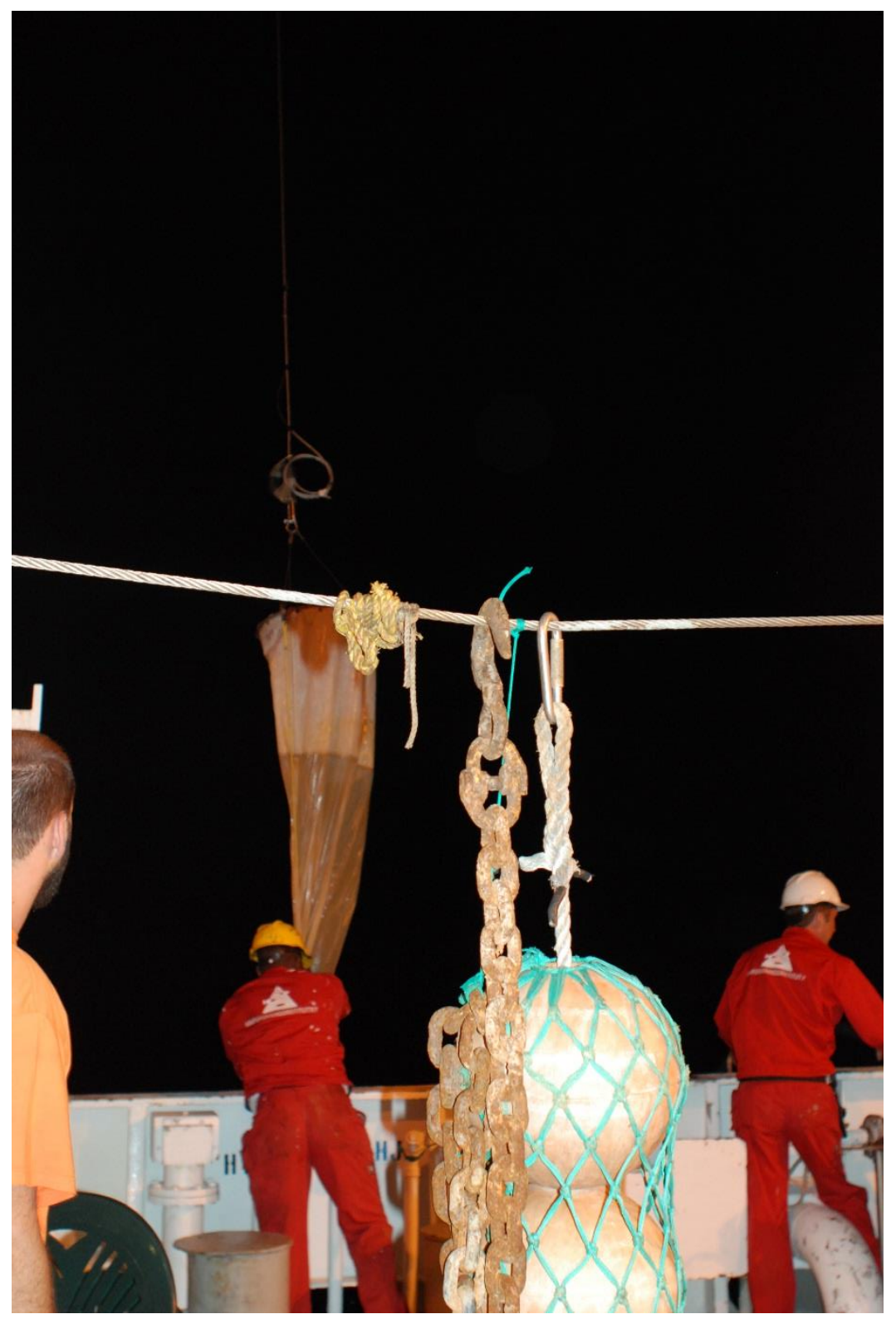


Figure 4

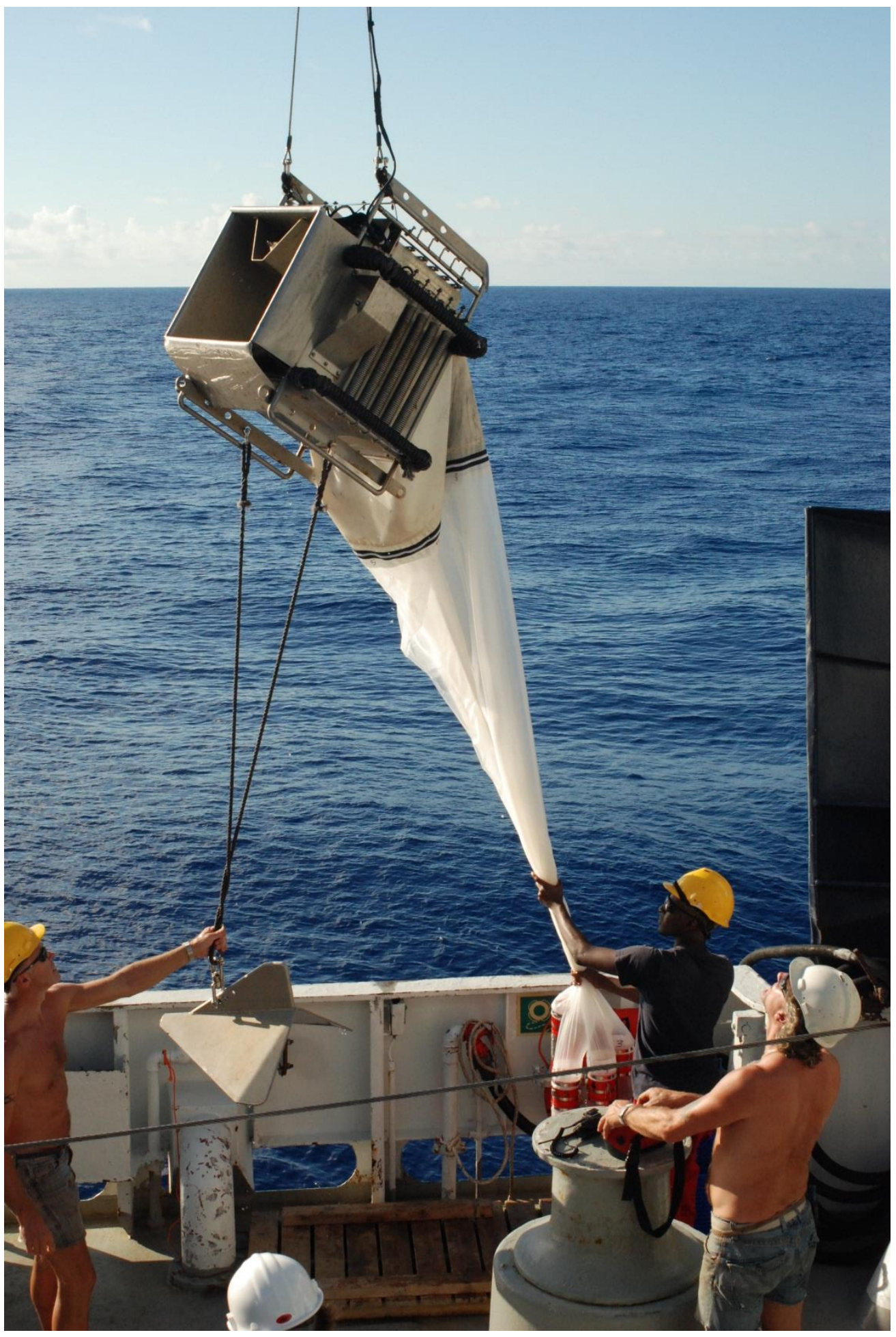


Figure 5

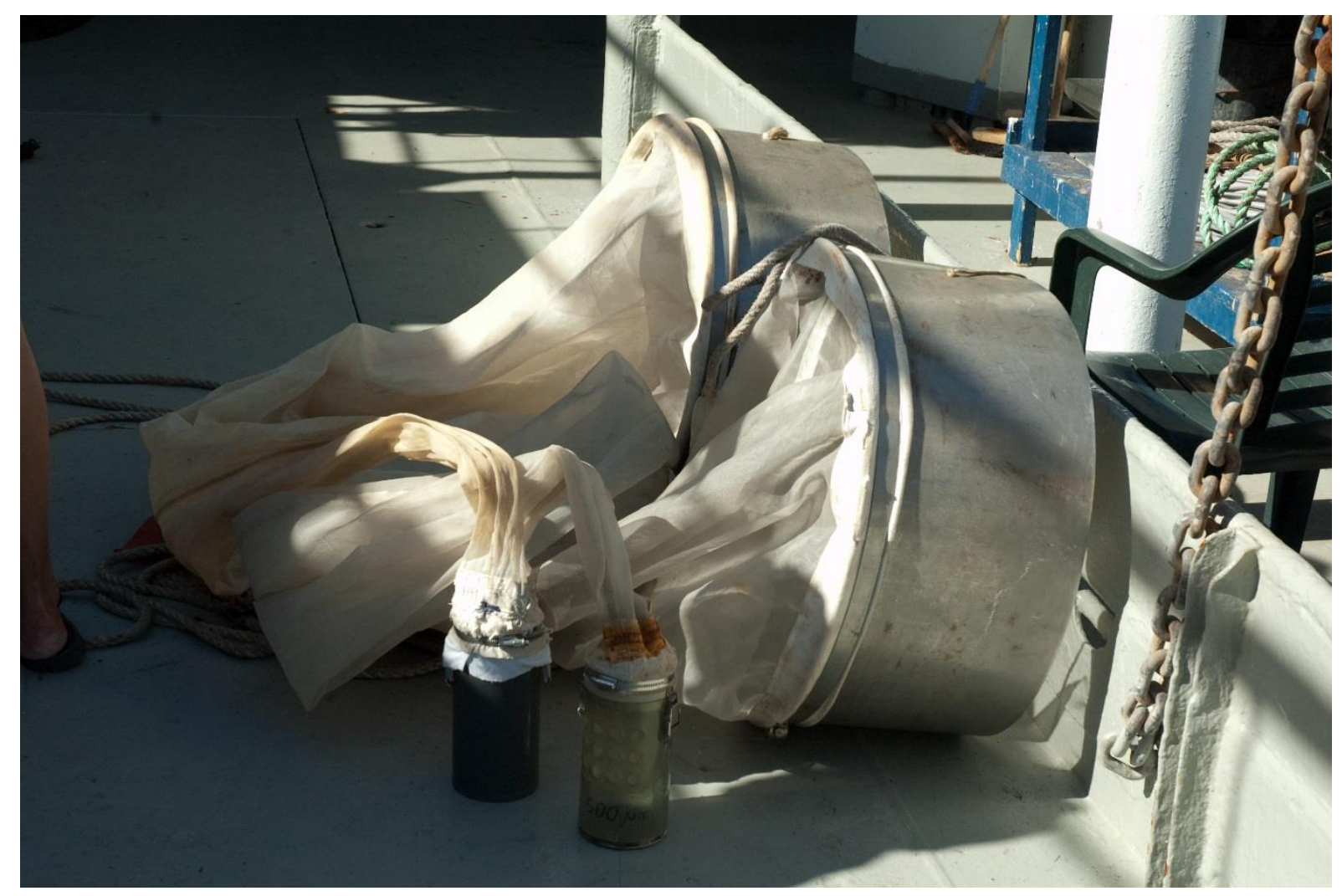


Figure 6

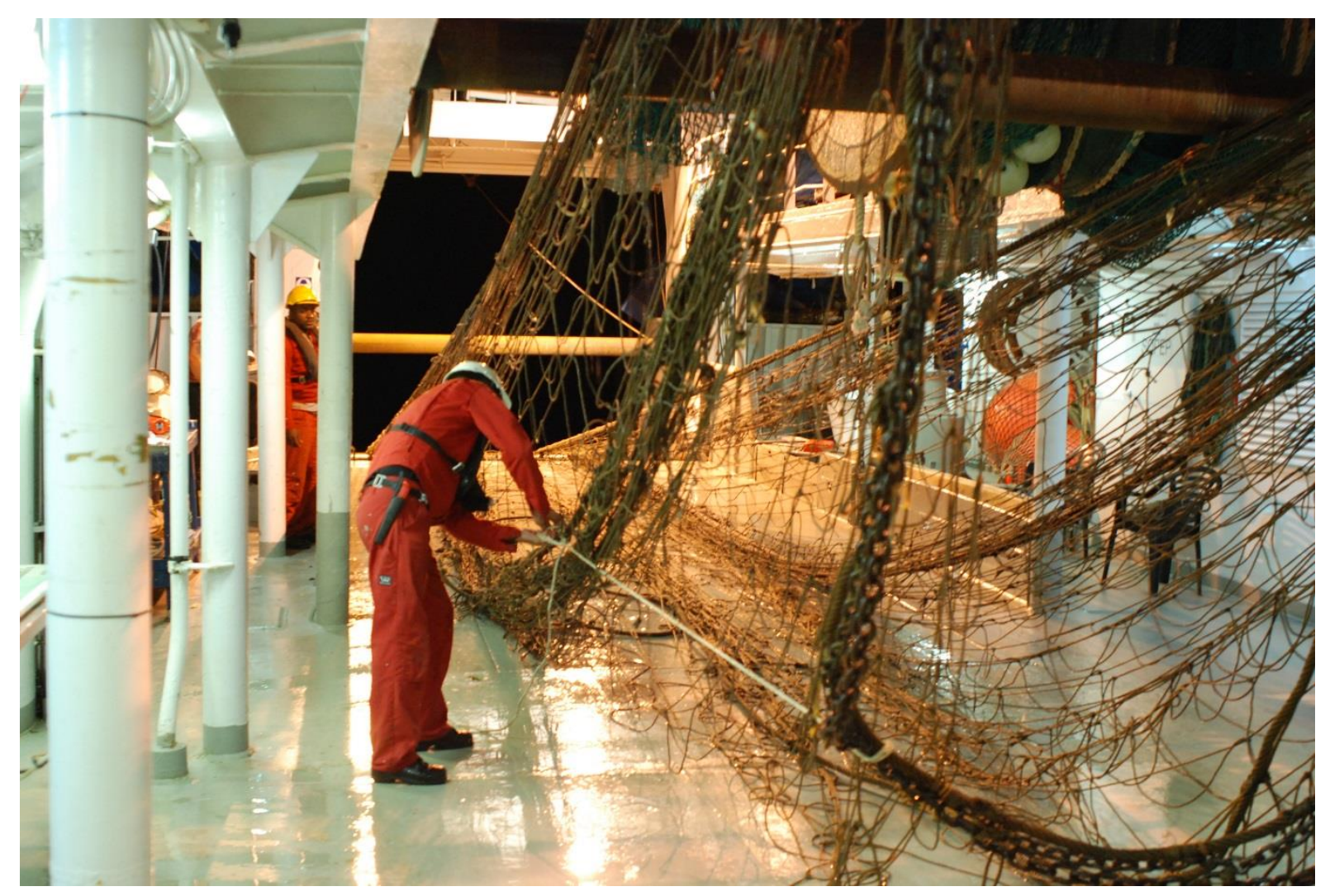


Figure 7

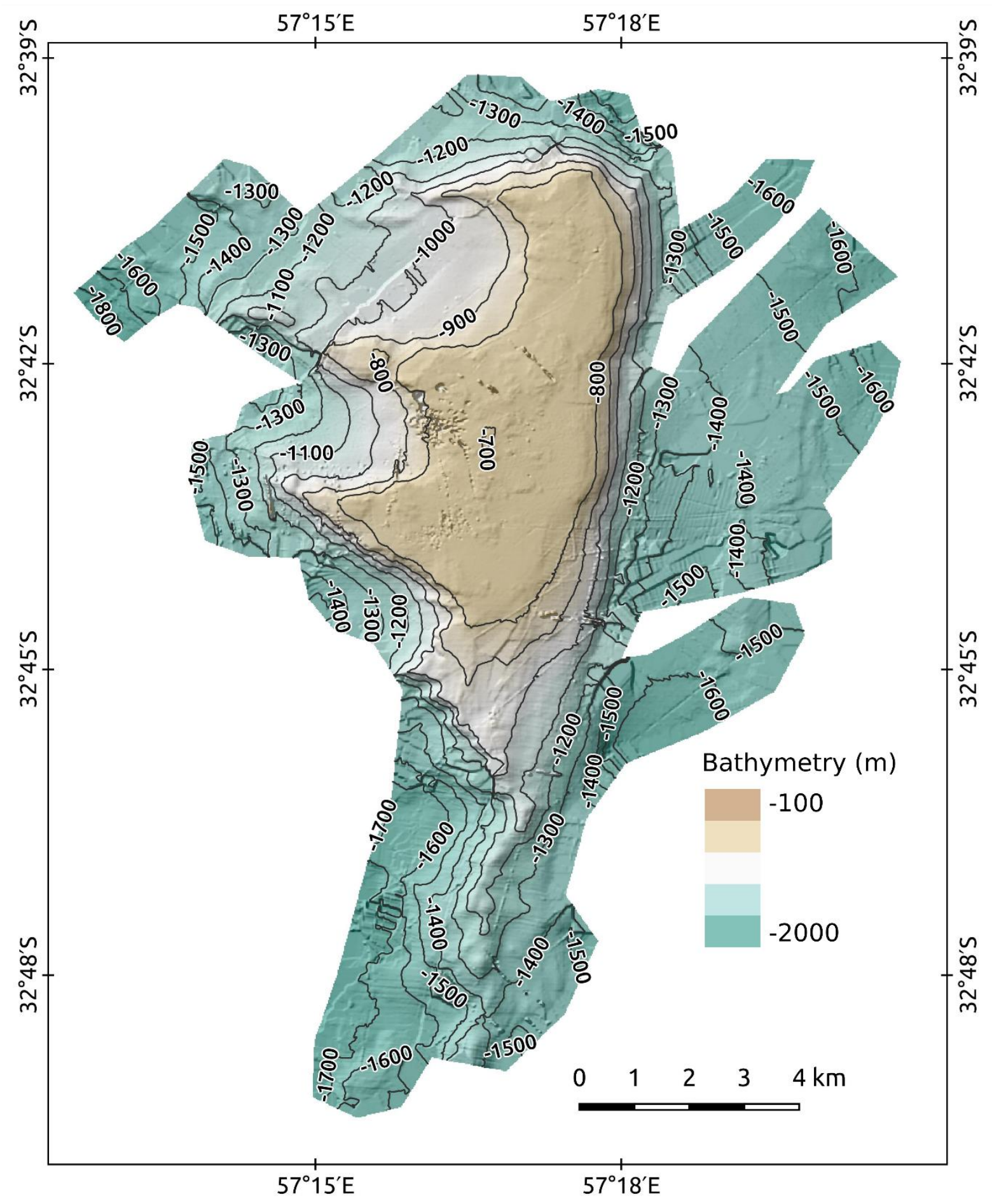


Figure 8

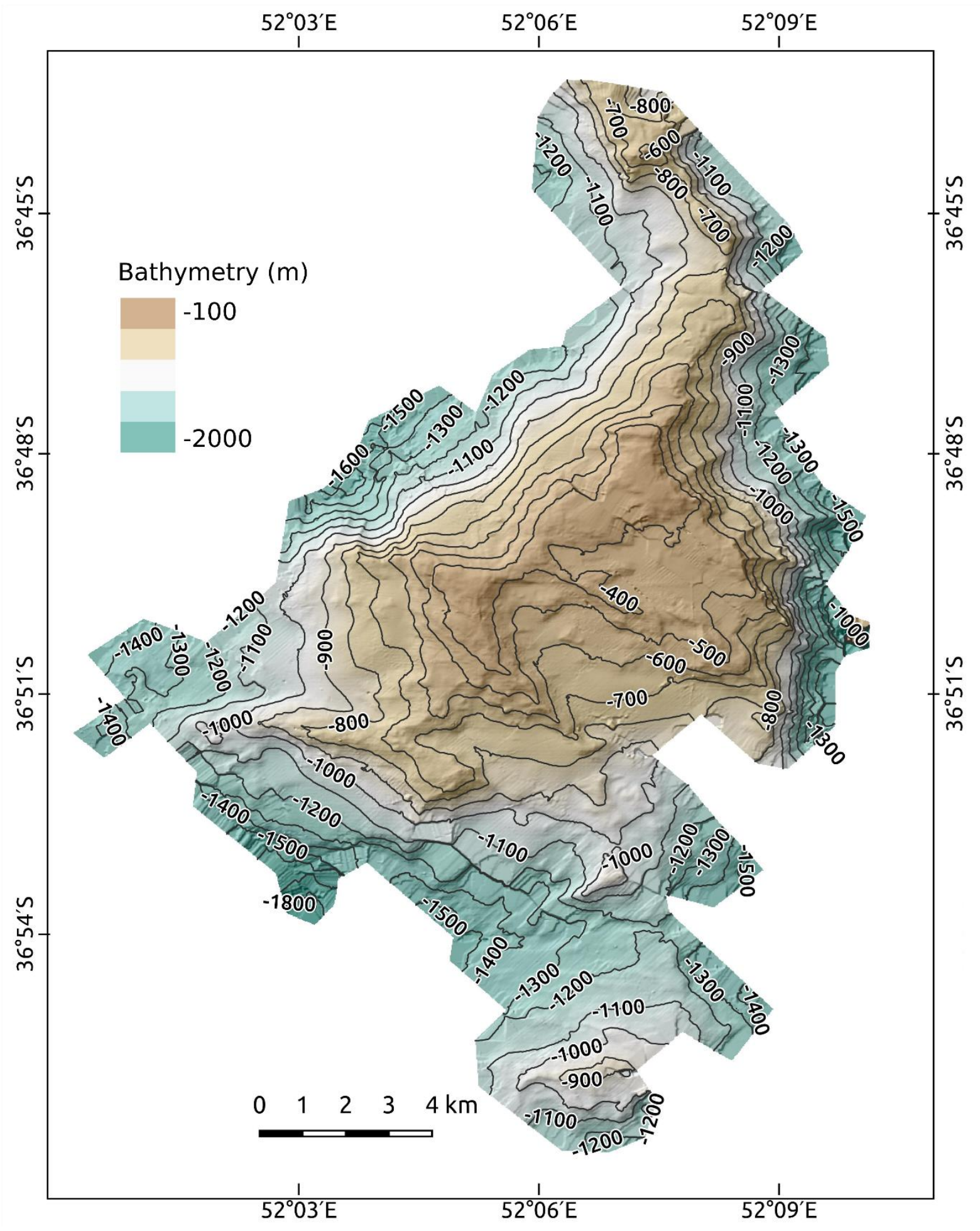


Figure 9

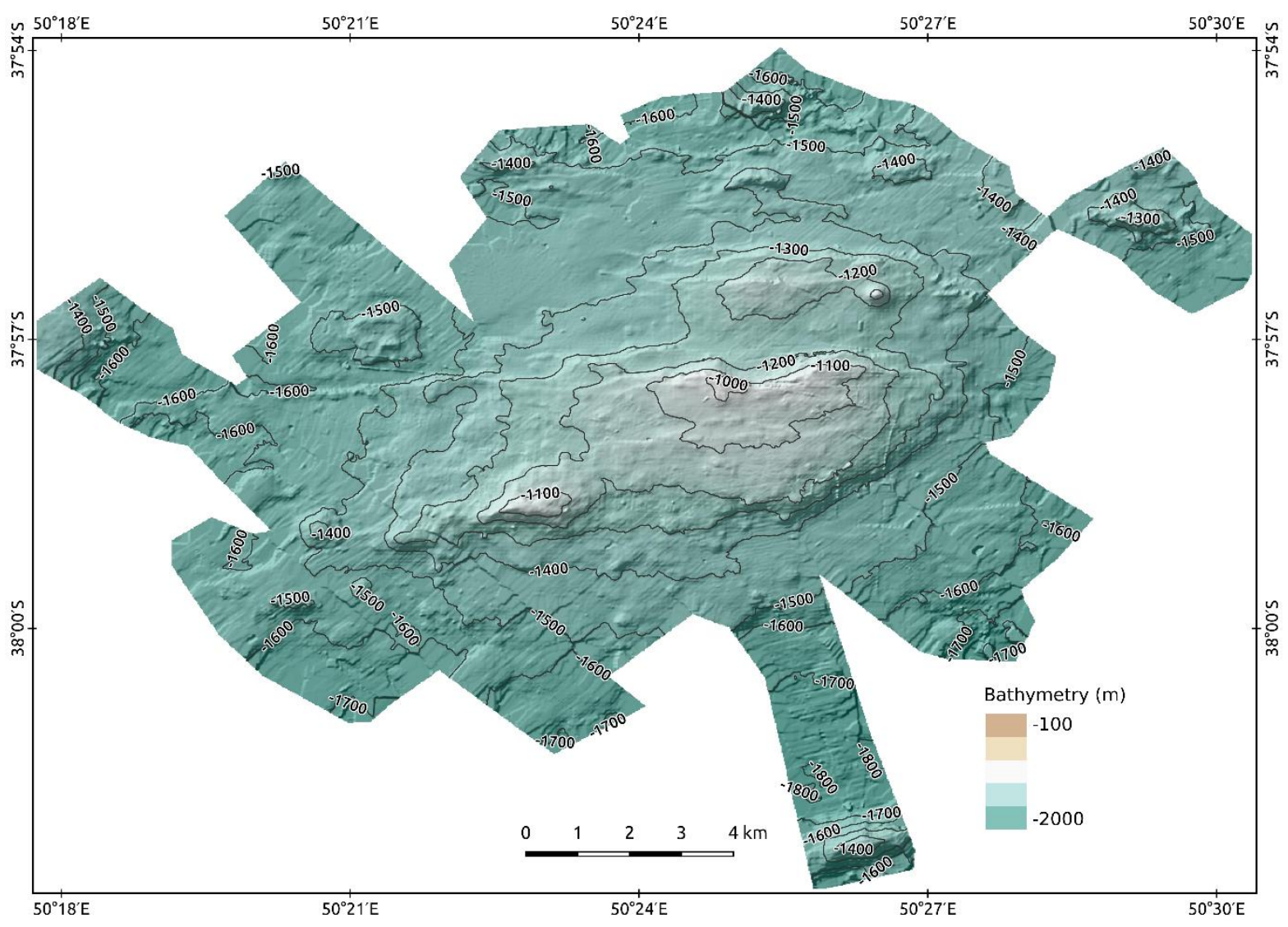


Figure 10

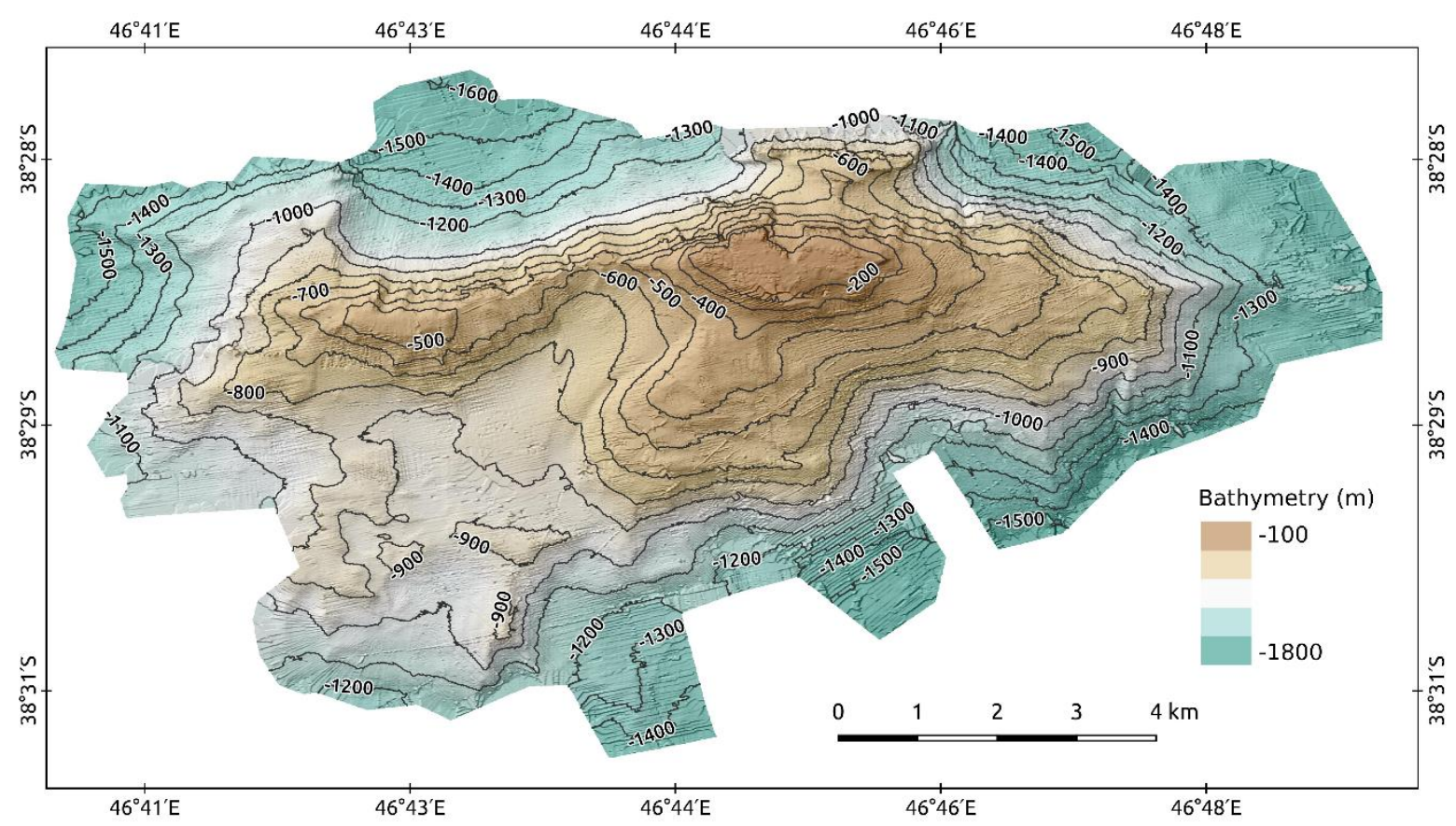


Figure 11

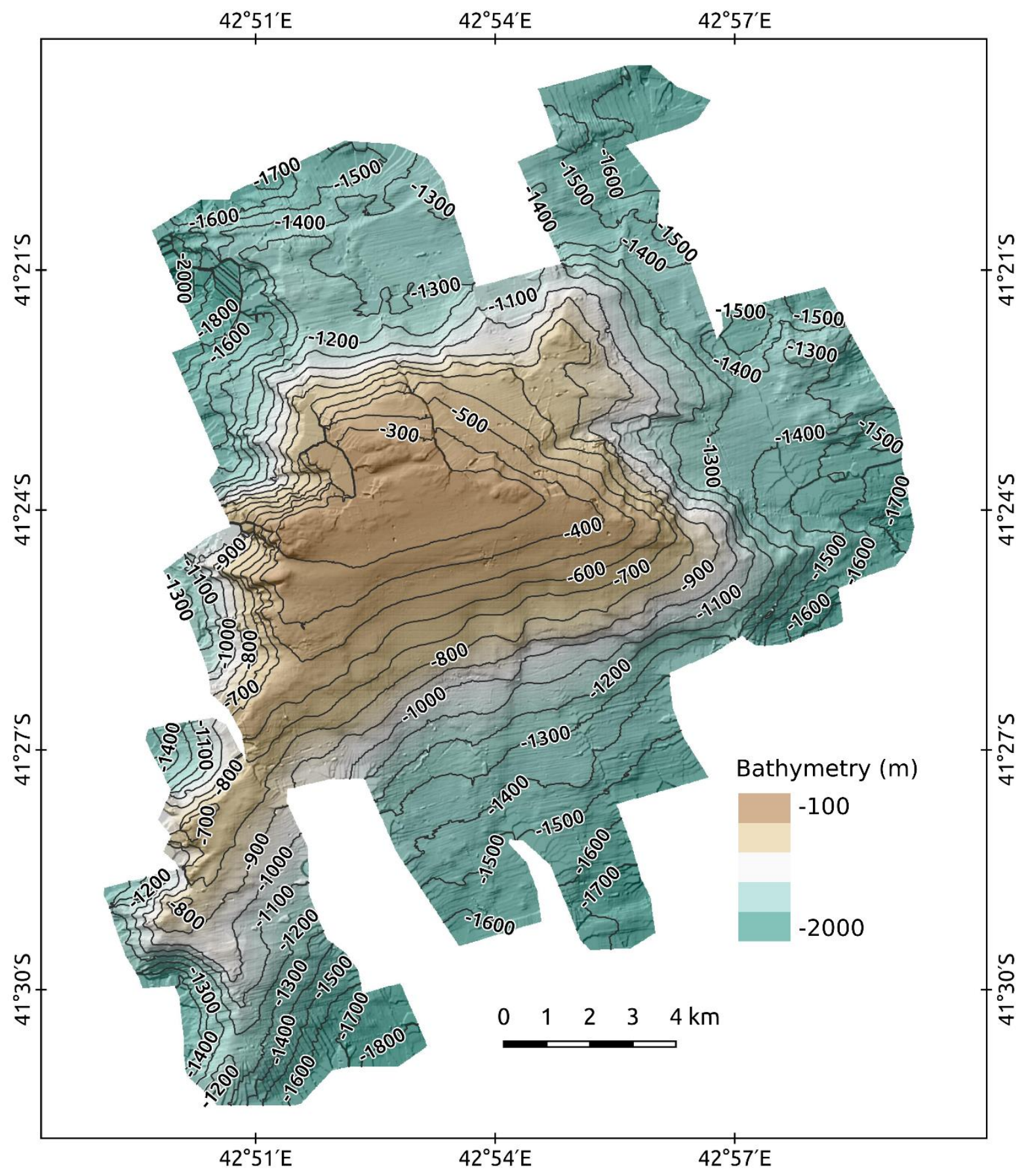


Figure 12

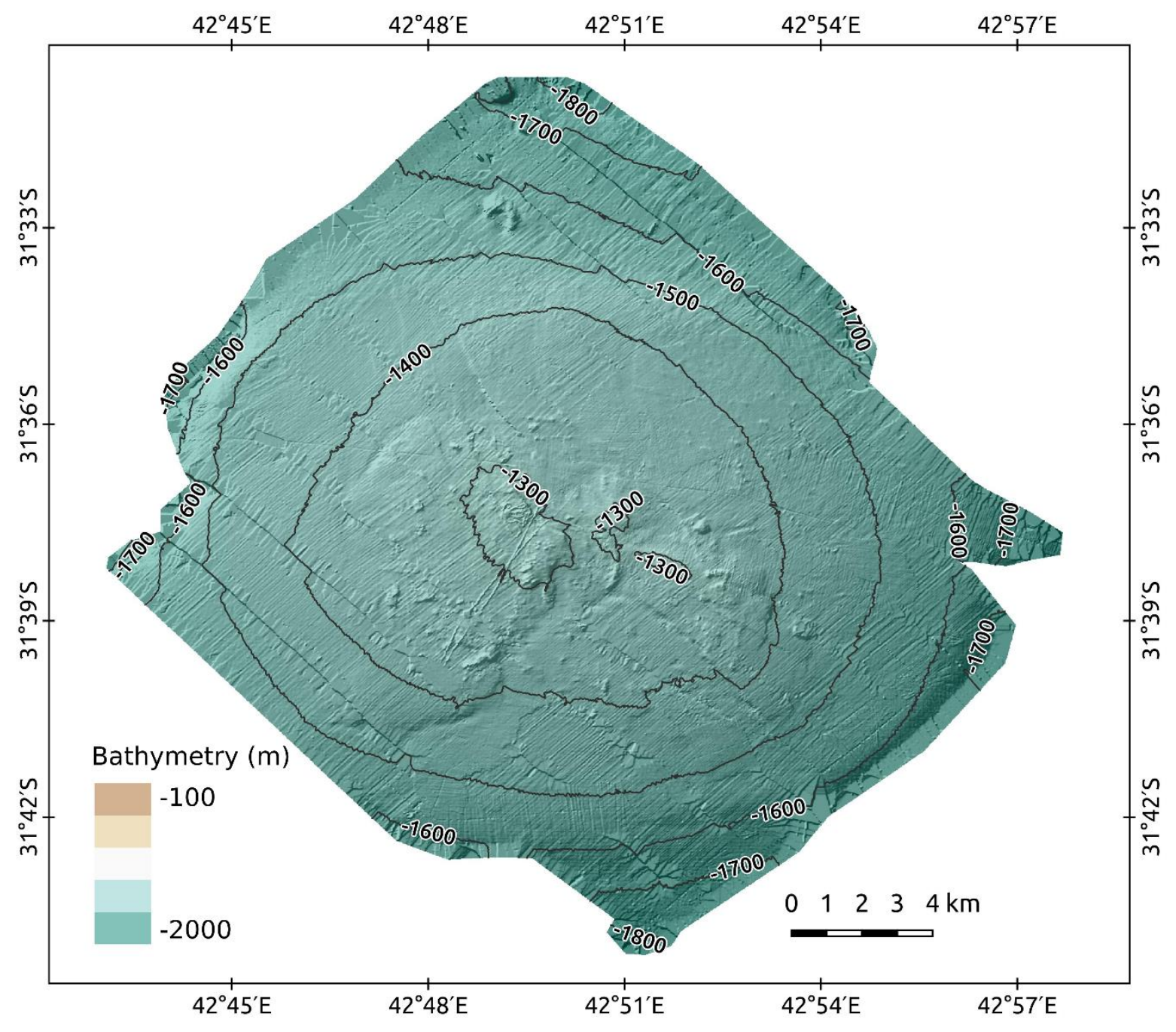


Figure 13
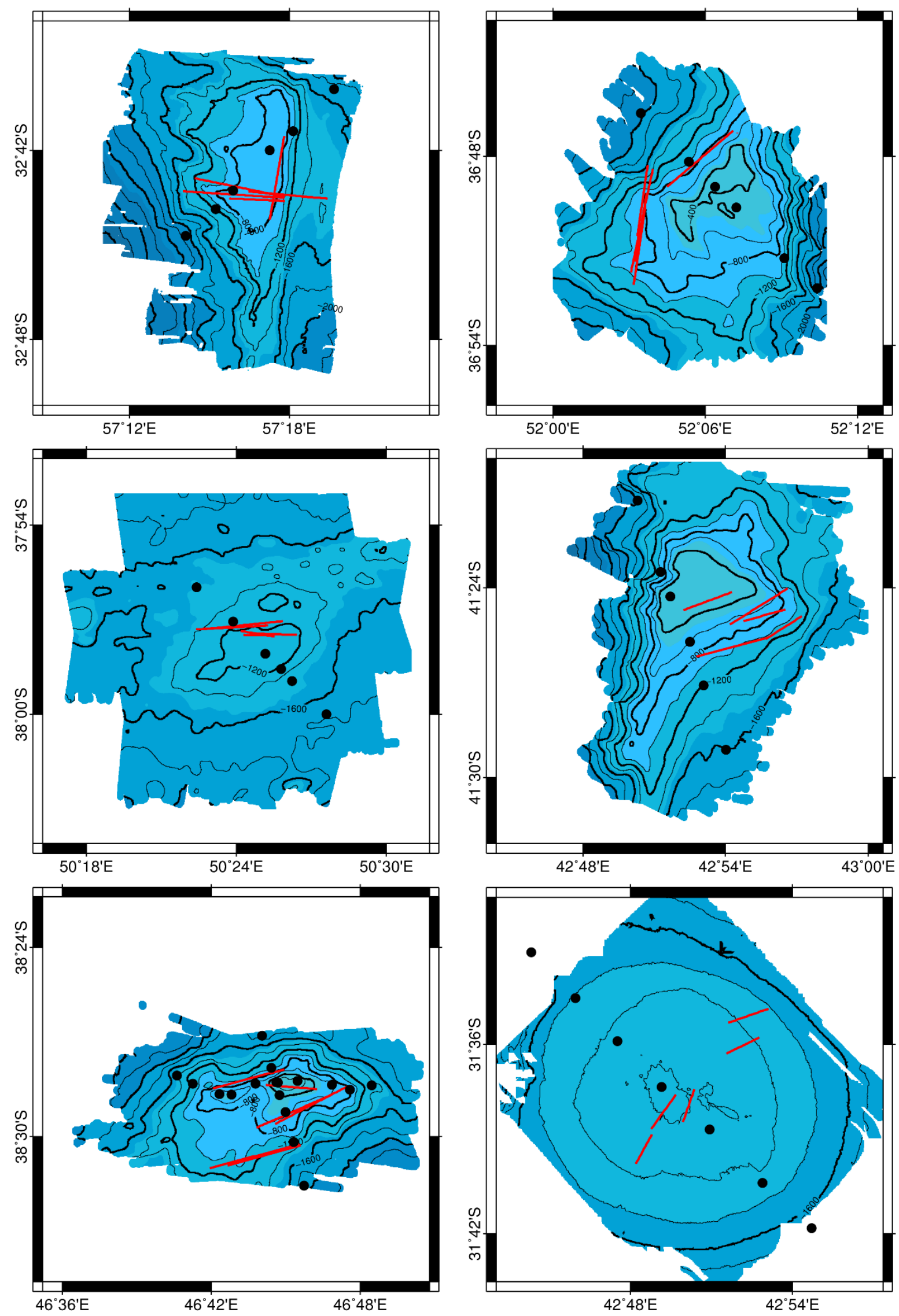
Figure 14

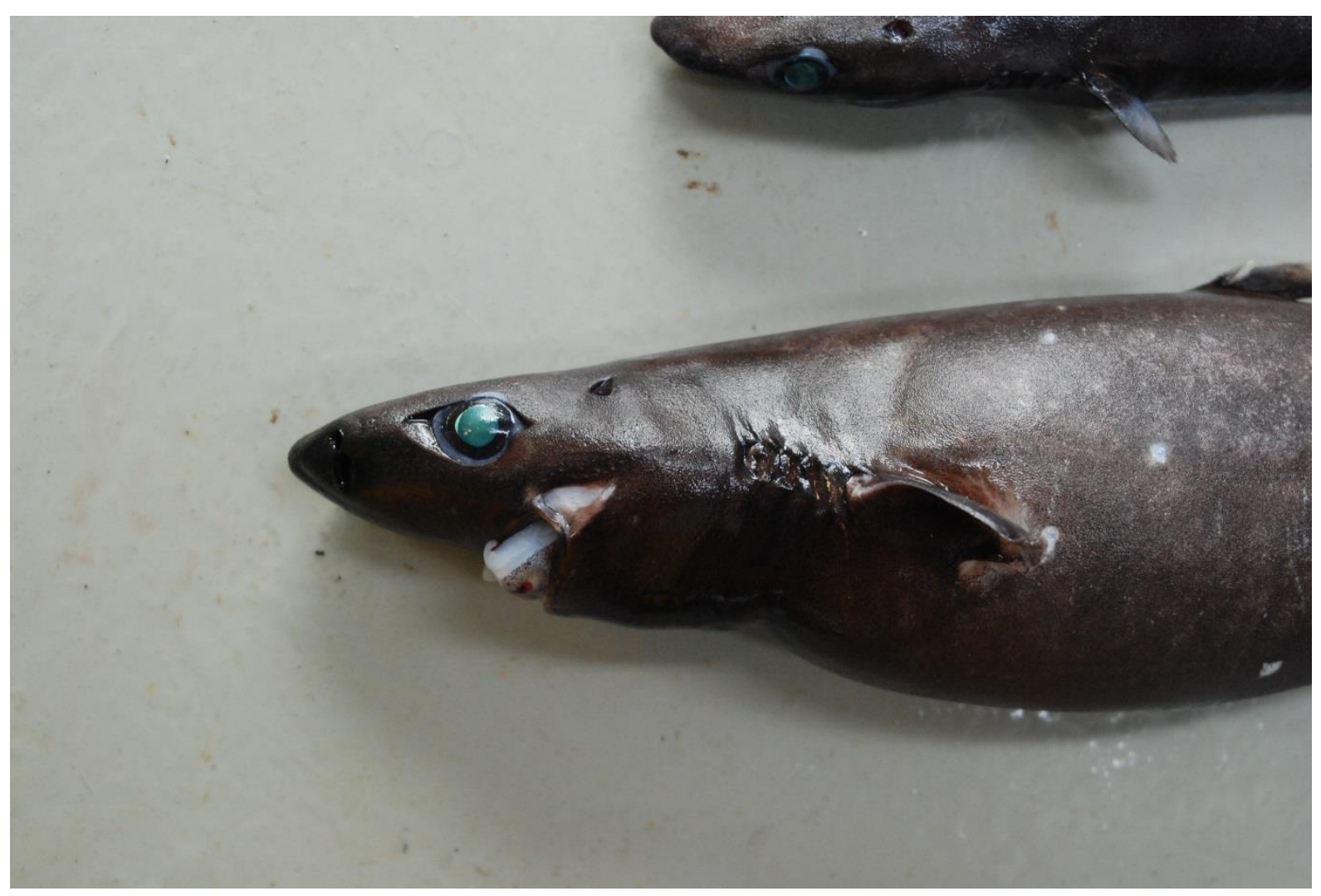


Figure 15

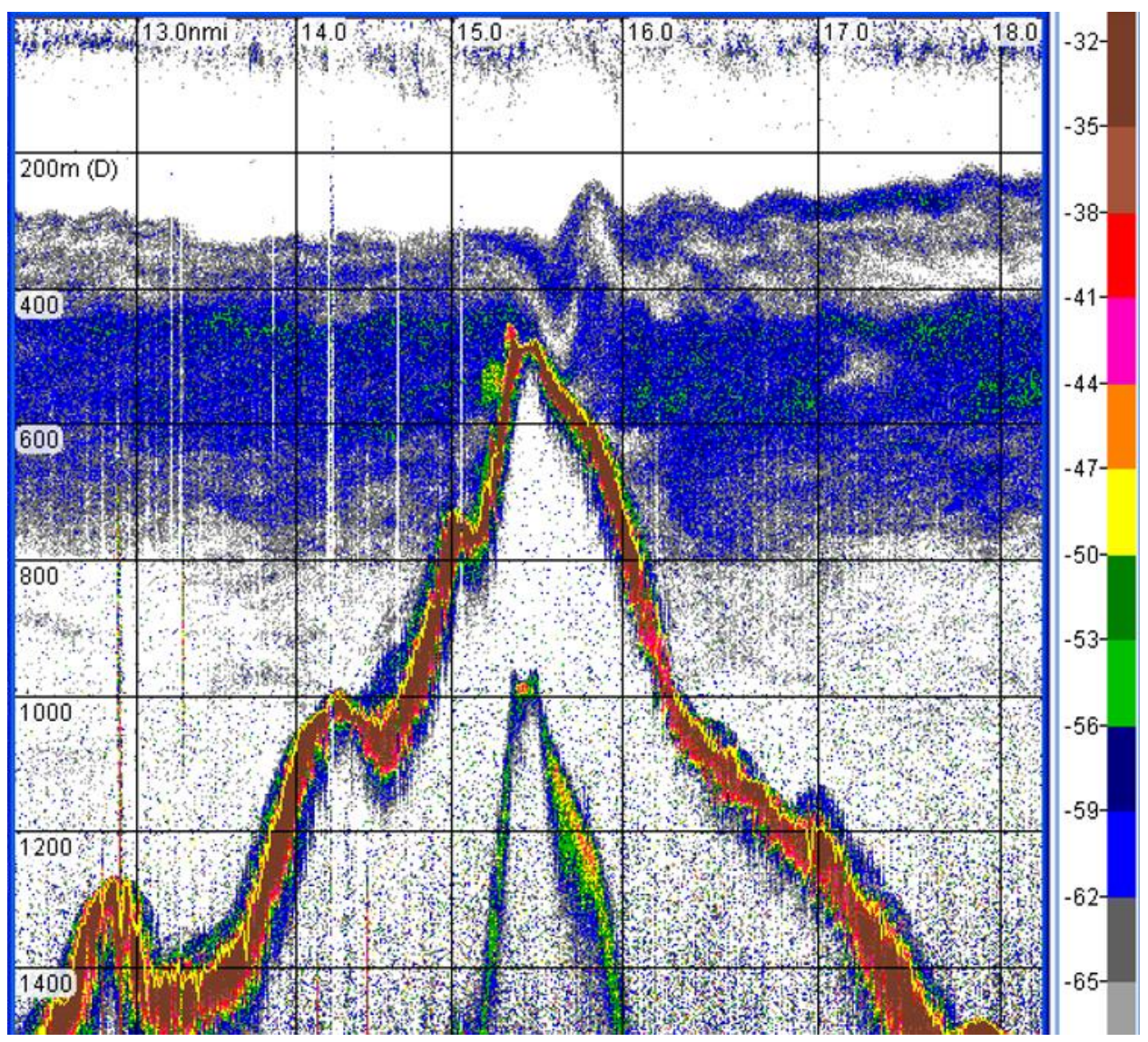


Supplementary Material

Calibration Parameter Chararteristics of EK60

Table S1 Calibration parameter estimates for the $18 \mathrm{kHz}$ echosounder

\begin{tabular}{|c|c|c|c|}
\hline \multicolumn{4}{|c|}{ Reference Target (CU-64): } \\
\hline TS & $-34.27 \mathrm{~dB}$ & Min. Distance & $18.00 \mathrm{~m}$ \\
\hline TS Deviation & $5.0 \mathrm{~dB}$ & Max. Distance & $23.00 \mathrm{~m}$ \\
\hline \multicolumn{4}{|c|}{ Transducer: ES18-11 Serial No. 593} \\
\hline Frequency & $18000 \mathrm{~Hz}$ & Beamtype & Split \\
\hline Gain & $20.76 \mathrm{~dB}$ & Two Way Beam Angle & $-17.0 \mathrm{~dB}$ \\
\hline Athw. Angle Sens. & 13.90 & Along. Angle Sens. & 13.90 \\
\hline Athw. Beam Angle & $11.19 \mathrm{deg}$ & Along. Beam Angle & $11.23 \mathrm{deg}$ \\
\hline Athw. Offset Angle & $0.04 \mathrm{deg}$ & Along. Offset Angl & $0.10 \mathrm{deg}$ \\
\hline SaCorrection & $-0.62 \mathrm{~dB}$ & Depth & $0.00 \mathrm{~m}$ \\
\hline \multicolumn{4}{|c|}{ Transceiver: GPT 18 kHz 00907205973e 1-1 ES18-11 } \\
\hline Pulse Duration & $1.024 \mathrm{~ms}$ & Sample Interval & $0.194 \mathrm{~m}$ \\
\hline Power & $2000 \mathrm{~W}$ & Receiver Bandwidth & $1.57 \mathrm{kHz}$ \\
\hline \multicolumn{4}{|l|}{ Sounder Type: } \\
\hline \multicolumn{4}{|l|}{ EK60 Version 2.2 .0} \\
\hline \multicolumn{4}{|l|}{ TS Detection: } \\
\hline Min. Value & $-50.0 \mathrm{~dB}$ & Min. Spacing & $100 \%$ \\
\hline Max. Beam Comp. & $6.0 \mathrm{~dB}$ & Min. Echolength & $80 \%$ \\
\hline Max. Phase Dev. & 8.0 & Max. Echolength & $180 \%$ \\
\hline
\end{tabular}




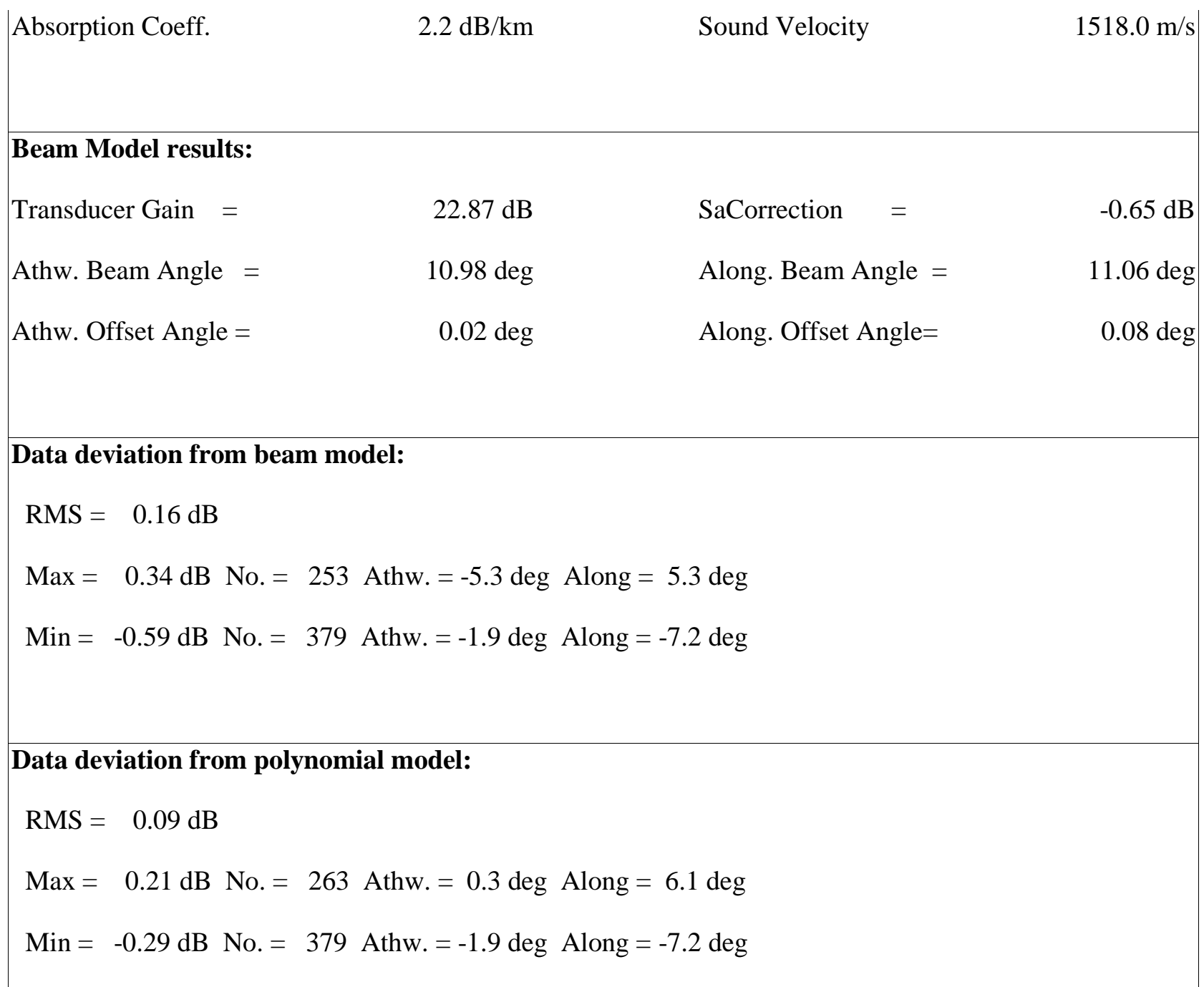

